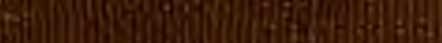

(1)

(1)

ifistis

$$
\text { H) }
$$

是青
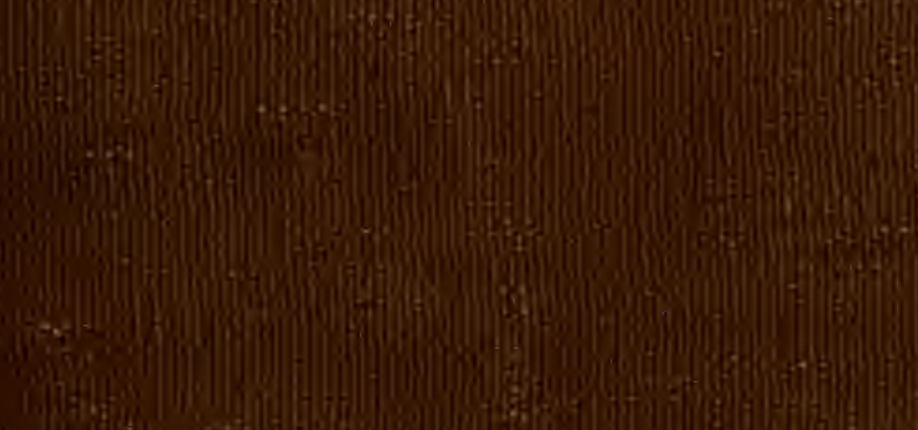

f.
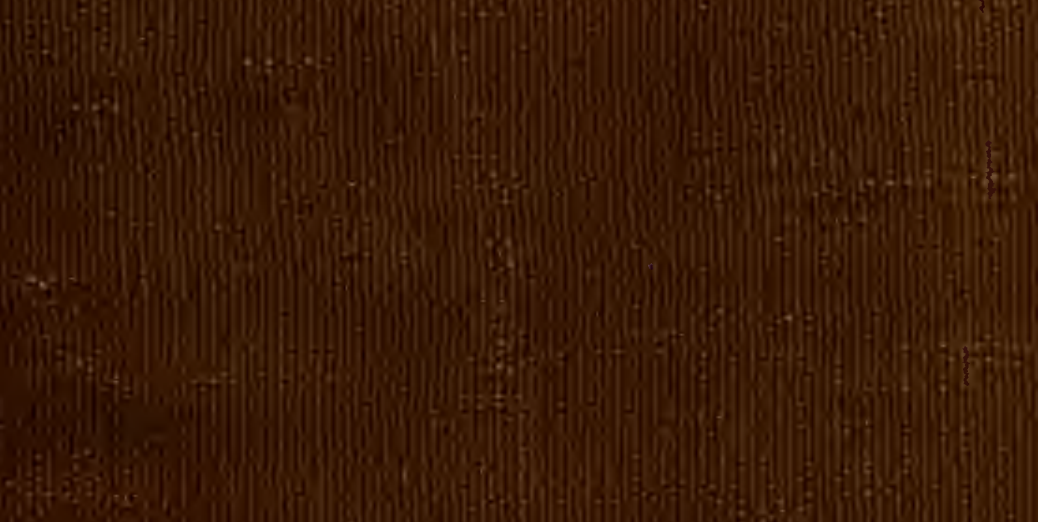

$$
\text { (1) }
$$

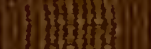




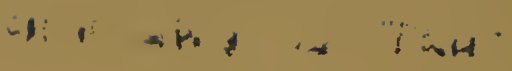
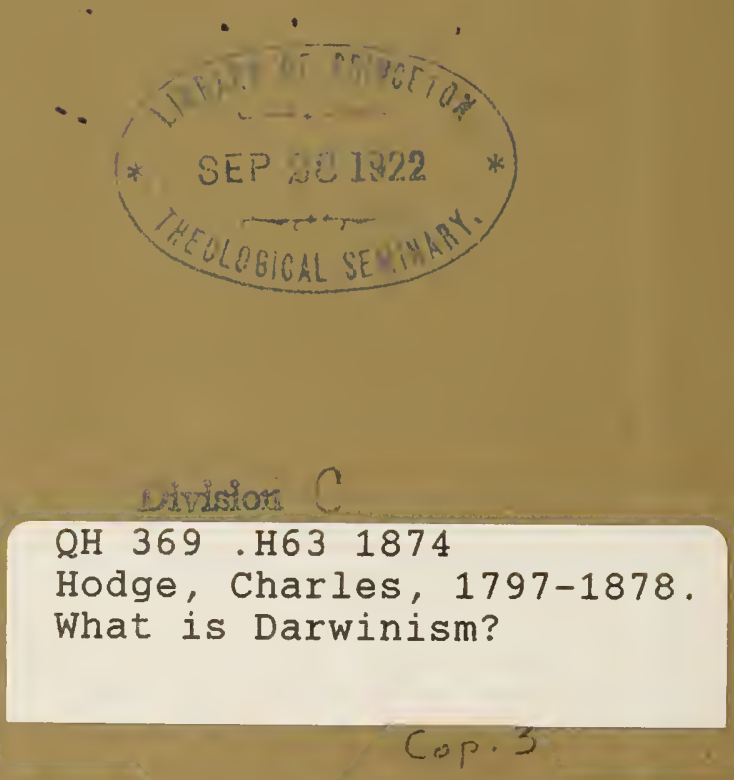




$$
y_{x}=x-x, x^{2}
$$





\title{
WHAT IS DARWINISM?
}

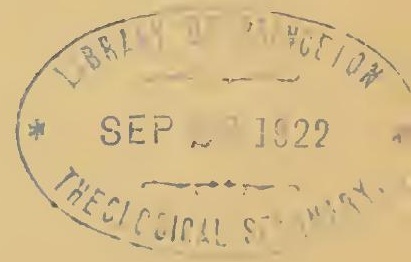

\author{
BY \\ CHARLES HODGE, \\ PLINCETON, N. J.
}

N E W Y OR :

SCRIBNER, ARMSTRONG, AND COMPANY.

$18 \pi 4$. 
Entered according to Act of Congress, in the year 1874, by Scribner, Arustrona, \& Company, in the Office of the Librarian of Congress, at Washington.

RIVERSIDE, CAMBRIDGE : 


\section{CONTENTS.}

ImPortance of THE QUestion

Different Theories as to the Origin of tile Universe, and specially of Vegetable and Animal Organisms.

1. The Scriptural Theory . . . . . . 3

2. The Pantheistic Theory . . . . . . . 7

3. The Epicurean Theory . . . . . . 10

4. The Doctrine of Herbert Spencer . . . . . 11

5. Hylozoic Theory . . . . . . . . 21

6. Unscriptural Forms of Theism . . . . . 22

Dariwin's Theory . . . . . . . . . 26

Natdral Selection . . . . . . . . 31

Sense in which Darifin uses the Word Natural . . 40

The Three Elements of Darwinism • . • . . 48

The Exclusion of Design in Nature the Formative Idea op Darwin's Theory . . . . . . . 49

Proof of Darwin's Denial of 'Teleologt, from his ow

Writings . . . . . . . . . 53

Proof from the Expositions of IIS Theory by its avowed ADrocates.

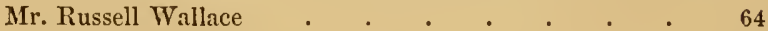

Professor Huxley . . . . . . . . 72

Dr. Büchner . . . . . . . . . 84

Carl Vogt . . . . . . . . . . 85

Prof. Haeckel . . . . . . . . . 87

Strauss . . . . . . . . . . 147

Proof from the Objections trged by the Opponents of Mr. DarWin's THEORY.

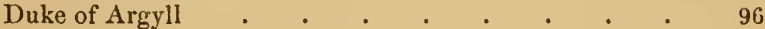

Agassiz . . . . . . . . . . 101

Professor Janet . . . . . . . . 105

M. Flourens . . . . . . . . . 108

Rev. Walter Mitchell . . . . . . . 111

Principal Dawson . . . . . . . . 119

Relation of Darwinisu to Religion . . . . 125 
Cadses of the Antagonism between Science and ReLIGION * . . . . . . . . . . 126 The Evolution Theory contrart to Facts and to ScripTURE . • • • • • • . • • • 141 Sir William Thouson on Thleologr . . . . . 165 Dr. Asa Gray . . . . . . . . . 174 Darwinism tantamount to Atheism . . . . . 177 


\section{WHAT IS DARWINISM?}

THIs is a question which needs an answer. Great confusion and diversity of opinion prevail as to the real views of the man whose writings have agitated the whole world, scientific and religious. If a man says he is a Darwinian, many understand him to avow himself virtually an atheist; while another understands him as saying that he adopts some harmless form of the doctrine of evolution. This is a great evil.

It is obviously useless to discuss any theory until we are agreed as to what that theory is. The question, therefore, What is Darwinism? must take precedence of all discussion of its merits.

The great fact of experience is that the universe exists. The great problem which has ever pressed upon the human mind is to account for its existence. What was its origin? To what causes are the changes we witness 
around us to be referred? As we are a part of the universe, these questions concern ourselves. What are the origin, nature, and destiny of man? Professor Huxley is right in saying, "The question of questions for mankind - the problem which underlies all others, and is more interesting than any other - is the ascertainment of the place which Man occupies in nature and of his relation to the universe of things. Whence our race has come, what are the limits of our power over nature, and of nature's power over is, to what goal are we tending, are the problems which present themselves anew and with undiminished interest to every man born into the world." 1 Mr. Darwin undertakes to answer these questions. He proposes a solution of the problem which thus deeply concerns every living man. Darwinism is, therefore, a theory of the universe, at least so far as the living organisms on this earth are concerned. This being the case, it may be well to state, in few words, the other prevalent theories on this great subject, that the points of agreement and of difference between them and the views of Mr. Darwin may be the more clearly seen.

1 Evidences of Man's Place in Nature. London, 1864, p. 57. 
The Scriptural Solution of the Problem of the Universe.

That solution is stated in words equally simple and sublime: "In the beginning God created the heavens and the earth." We have here, first, the idea of God. The word God has in the Bible a definite meaning. It does, not stand for an abstraction, for mere force, for law or ordered sequence. God is a spirit, and as we are spirits, we know from consciousness that God is, (1.) A Substance; (2.) That He is a person; and, therefore, a self-conscious, intelligent, voluntary agent. He can say I; we can address Him as Thou; we can speak of Him as He or Him. This idea of God pervades the Scriptures. It lies at the foundation of natural religion. It is involved in our relig. ious consciousness. It enters essentially into our sense of moral obligation. It is inscribed ineffaceably, in letters more or less legible, on the heart of every human being. The man who is trying to be an atheist is trying to free himself from the laws of his being. He might as well try to free himself from liability to hunger or thirst.

The God of the Bible, then, is a Spirit, inf- 
nite, eternal, and unchangeable in his being, wisdom, power, holiness, goodness, and truth. As every theory must begin with some postulate, this is the grand postulate with which the Bible begins. This is the first point.

The second point concerus the origin of the universe. It is not eternal either as to matter or form. It is not independent of God. It is not an evolution of his being, or his existence form. He is extramundane as well as antemundane. The universe owes its existence to his will.

Thirdly, as to the nature of the universe; it is not a mere phenomenon. It is an entity, having real objective existence, or actuality. This implies that matter is a substance endowed with certain properties, in virtue of which it is capable of acting and of being acted upon. These properties being uniform and constant, are physical laws to which, as their proximate causes, all the phenomena of nature are to be referred.

Fourthly, although God is extramundane, He is nevertheless everywhere present. That presence is not only a presence of essence, but also of knowledge and power. He upholds all things. He controls all physical 
causes, working through thein, with them, and without them, as He sees fit. As we, in our limited spheres, can use physical causes to accomplish our purposes, so God everywhere and always coöperates with them to accomplish his infinitely wise and merciful designs.

Fifthly, man a part of the universe, is, according to the Scriptures, as concerns his body, of the earth. So far, he belongs to the animal kingdom. As to his soul, he is a child of God, who is declared to be the Father of the spirits of all men. God is a spirit, and we are spirits. We are, therefore, of the same nature with God. We are God-like; so that in knowing ourselves we know God. No man conscious of his manhood can be ignorant of his relationship to God as his Father.

The truth of this theory of the universe rests, in the first place, so far as it has been correctly stated, on the infallible authority of the Word of God. In the second place, it is a satisfactory solution of the problem to be solved, - (1.) It accounts for the origin of the universe. (2.) It accounts for all the universe contains, and gives a satisfactory explanation of the marvellous contrivances which abound in living organisms, of the adaptations of these or- 
ganisms to conditions external to themselves, and for those provisions for the future, which on any other assumption are utterly inexplicable. (3.) It is in conflict with no truth of reason and with no fact of experience. ${ }^{-1}$ (4.) The Scriptural doctrine accounts for the spiritual nature of man, and meets all his spiritual necessities. It gives him an object of adoration, love, and confidence. It reveals the Being on whom his

1 The two facts which are commonly urged as inconsistent with Theism, are the existence of misery in the world, and the ocemrence of undeveloped or useless organs, as teeth in the jaws of the whale and mamme on the breast of a man. As to the former objection, sin, which is the only real evil, is accounted for by the voluntary apostasy of man; and as to undeveloped organs they are regarded as eridences of the great plan of structure which can be tracel in the different orders of animals. These unused organs were - says Professor Joseph Le Conte, in his interesting volume on Religion and Science, New York, 1874 , p. 54 - regarded as blunders in nature, until it was discovered that use is not the only end of design. "By further patient study of nature," he says, "came the recognition of another law beside use, - a law of order underlying and conditioning the law of use. Organisms are, indeed, contrived for use, but according to a preordained plin of structure, which must not be violated." It is of little moment whether this explanation be consilered satisfactory or not. It would certainly be irrational to refuse to believe that the eye was made for the purpose of vision, beeause we cannot tell why a man has mammæ. A man might as well refuse to admit that there is any meaning in all the writings of Plato, because there is a sentence in them which he cannot understand. 
indestructible sense of responsibility terminates. The truth of this doctrine, therefore, rests not only on the authority of the Scriptures, but on the very constitution of our nature. " The Bible has little charity for those who reject it. It pronounces them to be either derationalized or demoralized, or both.

\section{The Pantheistic Theory.}

This has been one of the most widely diffused and persistent forms of human thought on this whole subject. It has been for thousands of years not only the philosophy, but the religion of India, and, to a great extent, of China. It underlies all the forms of Greek philosophy. It erept into the Church, coneealed under the disguise of Scriptural terminology, in the form of Neo-Platonism. It was constantly reappearing during the Middle Ages, sometimes in a philosophical, and sometimes a mystical form. It was revived by Spinoza in the seventeenth century, and subsequently beeame dominant in the philosophy and literature of Europe. It is coming up again. Some distinguished naturalists are swinging round from one pole to the opposite; from saying there is no God, to teaching that everything is God. 
Sometimes, one and the same book in one half teaches materialism, in the other half idealism : the one affirming that everything is matter, the other that matter is nothing, but that everything is mind, and mind is God.

The leading principles of the Pantheistic theory are, - (1.) That there is an Infinite and Absolute Being. Of this Being nothing can be affirmed but actuality. It is denied that it is conscious, intelligent, or voluntary. (2.) It is subject to the blind necessity of self-evolution or development. (3.) This development being necessary is constant; from everlasting to everlasting. According to the Braminical doctrine, indeed, there are successive cycles of activity and repose, each cycle being measured by countless milliards of centuries.'According to the moderns, self-evolution being necessary, there can be no repose, so that Ohne Welt kein Gott. (4.) The Finite is, therefore, the existence form of the Infinite; all that is in the latter for the time being is in the former. All that is possible is actual. (5.) The Finite is the Infinite, or', to use theistic language, the World is God, in the sense that all the world is and contains is the form in which God, at each successive moment, exists. There is no 
power, save only the porver manifested in the world; no consciousness, intelligence, or voluntary activity, but in finite things, and the aggregate of these is the power, consciousness, intelligence, and activity of God. What we call sin is as much a form of God's activity as what we call virtue. In other words, there is no such thing as free agency in man, no such thing as sin or responsibility. When a man dies he sinks into the abyss of being as a drop of water is lost in the ocean. (6.) Man is the highest form of God's existence. God is incarnate in the human race. Strauss says, that what the Church teaches of Christ is not true of any individual man, but is true of mankind. Or, as Feuerbach more concisely expresses it, "Man alone is our God." The blasphemy of some of the German philosophers on this subject is simply unutterable. In India we see the practical operation of this system when it takes hold on the people. There the personification of the Infinite as evil (the Goddess Kala) is the most popular object of worship. 


\section{Epicurean Theory.}

Epicurus assumed the existence of matter, force and motion, — Stoff und Kraft. He held that all space was filled with molecules of matter in a state of rapid motion in every direction. These molecules were subject to gravity and endowed with properties or forces. One combination of molecules gave rise to unorganized matter, another to life, another to mind ; and from the various combinations, guided by unintelligent physical laws, all the wonderful organisms of plants and animals have arisen. To these combinations also all the phenomena of life, instinct, and intelligence in the world are to be referred. This theory has been adopted in our day by a large class of scientific men, especially in Germany. The modern advocates of the theory are immeasurably superior to the ancient Epicureans in their knowledge of astronomy, botany, zoölogy, and biology; but in their theory of the universe, and in their mode of accounting for all the phenomena of life and intelligence, they are precisely on the same level. They have not added an idea to the system, which has ever been regarded as the opprobrium of human 
thought. Büchner, Moleschott, Vogt, hold that matter is eternal and indestructible; that matter and force are inseparable: the one cannot exist without the other. What, it is asked, is motion without something moving? What is electricity without an electrified body? What is attraction without molecules attracting each other? What is contractibility without muscular fibre, or secretion without a secreting gland? One combination of molecules exhibits the phenomena of life, another combination exhibits the phenomena of mind. All this was taught by the old heathen philosopher more than two thousand years ago. That this system denies the existence of God, of mind as a thinking substance distinct from matter, and of the possibility of the conscious existence of man after death, are not inferences drawn by opponents, but conclusions openly avowed by its advocates.

\section{Herbert Spencer's Newo Philosophy.}

Mr. Darwin calls Spencer our "great philosopher." His is the speculating mind of the new school of science. This gives to his opinions special interest, although no one but himself is to be held responsible for his peculiar views, except so far as others see fit to avow 
them. Mr. Spencer postulates neither mund nor matter. He begins with Force. Force, however, is itself perfectly inscrutable. All we know about it is, that it is, that it is indestructible, and that it is persistent.

As to the origin of the universe, he says there are three possible suppositions: 1st. That it is self-existent. 2d. That it is selfcreated. 3d. That it is created by an external agency. ${ }^{1}$ All these he examines and rejects. The first is equivalent to Atheism, by which Spencer understands the doctrine which makes Space, Matter, and Force eternal and the causes of all phenomena. This, he says, assumes the idea of self-existence, which is unthinkable. The second theory he makes equivalent to Pantheism. "The precipitation of vapor," he says, "into cloud, aids us in forming a symbolic conception of a self-evolved universe;" but, he adds, "really to conceive self-creation, is to conceive potential existence passing into actual existence by some inherent necessity, which we cannot do." (p. 32). The Theistic theory, he says, is equally untenable. "Whoever agrees that the atheistic hypothesis is

1 First Principles of a New System of Philosophy. By Herbert Spencer. Second edition. New York, 1869, p. 30. 
untenable because it involves the impossible idea of self-existence, must perforce admit that the theistic hypothesis is untenable if it contains the same impossible idea." (p.38). The origin of the universe is, therefore, a fact which cannot be explained. It must have had a cause; and all we know is that its cause is unknowable and inscrutable.

When we turn to nature the result is the same. Everything is inscrutable. All we know is that there are certain appearances, and that where there is appearance there must be something that appears. But what that something is, what is the noumenon which underlies the phenomenon, it is impossible for us to know. In nature we find two orders of phenomena, or appearances; the one objective or external, the other subjective in our consciousness. There are an Ego and a nonEgo, a subject and object. These are not identical. "It is," he says, "rigorously impossible to conceive that our knowledge is a knowledge of appearances only, without at the same time conceiving a reality of which they are appearances, for appearance without reality is unthinkable." (p. 88). So far we can go. There is a reality which is the cause of phe- 
nomena. Further than that, in that direction, our ignorance is profound. He proves that space cannot be an entity, an attribute, or a category of thought, or a nonentity. The same is true of time, of motion, of matter, of electricity, light, magnetism, etc., etc. They all resolve themselves into appearances produced by an unknown cause.

As the question, What is matter? is a crucial one, he dwells upon it in various parts of his writings. Newton's theory of ultimate atoms; Leibnitz's doctrine of monads; and the dynamic theory of Boscovich, which makes matter mere centres of force, are all dismissed as unthinkable. It is not very clear in what sense that word is to be taken. Sometimes it seems to meall, meaningless; at others, self-contradictory or absurd; at others, inconceivable, $i$. e. that of which no conception or mental image can be formed; at any rate, it implies what is unknowable and untenable. The result is, so far as matter is concerned, that we know nothing about it. "Our conception of matter," he says, "reduced to its simplest shape, is that of coexistent positions that offer resistance, as contrasted with our conception of space in which the coexistent positions offer 
no resistance." (p. 166). Resistance, however, is a form of force; and, therefore, on the following page, Spencer says, "that forces standing in certain correlations, form the whole contents of our idea of matter."

When we turn from the objective to the subjective, from the external to the inward world, the result is still the same. He agrees with Hume in saying that the contents of our consciousness is a series of impressions and ideas. He dissents, however, from that philosopher, in saying that that series is all we know. He admits that impressions necessarily imply that there is something that is impressed. He starts the question, What is it that thinks? and answers, We do not know. (p. 63). $\mathrm{He}$ admits that the reality of individual personal minds, the conviction of personal existence is universal, and perhaps indestructible. Nevertheless that conviction cannot justify itself at the bar of reason; nay, reason is found to reject it. (p. 65). Dean Mansel says, that consciousness gives us a knowledge of self as a substance and not merely of its varying states. This, however, he says, "is absolutely negatived by the laws of thought. The fundamental condition to all consciousness, em- 
phatically insisted upon by Mr. Mansel in common with Sir William Hamilton and others, is the antithesis of subject and object..... What is the corollary from this doctrine, as bearing on the consciousness of self? The mental act in which self is known implies, like every other mental act, a perceiving subject and a perceived object. If, then, the object perceived is self, what is the sulject that perceives? Or if it is the true self which thinks, what other self can it be that is thought of? Clearly, a true cognition of self implies a state in which the knowing and the known are one - in which subject and object are identified; and this Mr. Mansel rightly holds to be the annihilation of both. So that the personality of which each is conscious, and of which the existence is to each a fact beyond all others the most certain, is yet a thing which cannot be known at all; knowledge of it is forbidden by the very nature of human thought." (pp. 65, 66).

Mr. Spencer does not seem to expect that any man will be shaken in his conviction by any such argument as that. When a man is conscious of pain, he is not to be puzzled by telling him that the pain is one thing (the object perceived) and the self another thing (the 
perceiving subject). He knows that the pain is a state of the self of which he is conscious. Consciousness is a form of knowledge; but knowledge of necessity supposes an intelligent reality which knows. A philosophy which cannot be received until men cease to believe in their own existence, must be in extremis.

Mr. Spencer's conclusion is, that the universe - nature, or the external world with all its marvels and perpetual changes, - the world of consciousness with its ever varying states, are impressions or phenomena, due to an inscrutable, persistent force.

As to the nature of this primal force or power, he quotes abundantly and approvingly from Sir William Hamilton and $\mathrm{Mr}$. Mansel, to prove that it is unknowable, inconceivable, unthinkable. He, however, differs from those distinguished writers in two points. While admitting that we know no more of the first cause than we do of a geometrical figure which is at once a circle and a square, yet we do know that it is actual. For this conviction we are not dependent on faith. In the second place, Hamilton and Mansel taught that we know that the Infinite cannot be a person, self-conscious, intelligent, and voluntary; yet 
we are forced by our moral constitution to believe it to be an intelligent person. This Mr. Spencer denies. "Let those," he says, "who can, believe that there is eternal war between our intellectual faculties and our moral obligations. I, for one, admit of no such radical vice in the constitution of things." (p. 108). Religion has always erred, he asserts, in that while it teaches that the Infinite Being cannot be known, it insists on ascribing to it such and such attributes, which of course assumes that so far forth it is known. We have no right, he contends, to ascribe personality to the "Unknown Reality," or anything else, except that it is the cause of all that we perceive or experience. There may be a mode of being, as much transcending intelligence and will, as these transcend mechanical motion. To show the folly of referring to the Unknown the attributes of our own spirits, he makes "the grotesque supposition that the tickings and other movements of a watch constituted a kind of consciousness; and that a watch possessed of such a consciousness, insisted on regarding the watchmaker's actions as determined like its own by springs and escapements." (p.111). The vast majority of men, instead of agreeing 
with Mr. Spencer in this matter; will doubtless heartily, each for himself, join the German philosopher Jacobi, in saying, "I confess to Anthropomorphism inseparable from the conviction that man bears the image of God; and maintain that besides this Anthropomorphism, which has always been called Theism, is nothing but Atheism or Fetichism." 1

Mr. Spencer, therefore, in accounting for the origin of the universe and all its phenomena, physical, vital, and mental, rejects Theism, or the doctrine of a personal God, who is extramundane as well as antemundane, the creator and governor of all things; he rejects Pantheism, which makes the finite the existence-form of the Infinite; lie rejects Atheism, which he understands to be the doctrine of the eternity and self-existence of matter and force. He contents himself with saying we must acknowledge the reality of an unknown something which is the cause of all things, - the noumenon of all phenomena. "If science and religion are to be reconciled, the basis of the reconciliation must be this deepest, widest, and most certain of all facts, - that the Power which the

1 Von den göttlichen Dingen, Werke, III. pp. 422, 425. Leipzig, 1816. 
universe manifests is utterly inscrutable." ( $p$. 46). "The ultimate of ultimates is Force." "Matter and motion, as we know them, are differently conditioned manifestations of force." "If, to use an algebraic illustration, we represent Matter, Motion, and Force, by the symbols $x, y, z$; then we may ascertain the values of $x$ and $y$ in terms of $z$, but the value of $z$ can never be found; $z$ is the unknown quantity, which must forever remain unknown, for the obvious reason that there is nothing in which its value can be expressed." (pp. 169, 170).

We have, then, no God but Force. Atheist is everywhere regarded as a term of reproach. Every man instinctively recoils from it. Even the philosophers of the time of the French Revolution repudiated the charge of atheism, because they believed in motion; and motion being inscrutable, they believed in an inscrutable something, $i$. e. in Force. We doubt not Mr. Spencer would indignantly reject the imputation of atheism; nevertheless, in the judgment of most men, the difference between Antitheist and Atheist is a mere matter of orthography. 


\section{Hylozoic Theory.}

This theory assumes the universe to be eternal. There is nothing extra, or antemundane. There is but one substance, and that substance is matter. Matter, however, has an active and passive principle. Life and rationality are anong its attributes or functions. The universe, therefore, is a living whole pervaded by a principle not only of life but of intelligence. This hylozoic doctrine, some modern scientific men, as Professor Tyndall, seem inclined to adopt. They tell us that matter is not the dead and degraded thing it is commonly regarded. It is active and transcendental. What that means, we do not know. The word transcendental is like a parabola, in that there is no knowing where its meaning ends. To say that matter is transcendental, is saying there is no telling what it is up to. This habit of using words which have no definite meaning is very convenient to writers, but very much the reverse for readers. Some of the ancient Stoics distinguished between the active and passive principles in the world, calling the one mind, the other, matter. These however were as intimately united as matter and life in a plant or animal. 


\section{Theism in Unscriptural Forms.}

There are men who are constrained to admit the being of God, who depart from the Scriptural doctrine as to his relation to the world. According to some, God created matter and endowed it with certain properties, and then left it to itself to work out, without any interference or control on his part, all possible results. According to others, He created not only matter, but life, or living germs, one or more, fronı which without any divine intervention all living organisms have been developed. Others, again, refer not only matter and life, but mind also to the act of the Creator; but with creation his agency ceases. He has no more to do with the world, than a ship-builder has with the ship he has constructed, when it is launched and far off upon the ocean. According to all these views a creator is a mere Deus ex machina, an assumption to account for the origin of the universe.

Another general view of God's relation to the world goes to the opposite extreme. Instead of God doing nothing, He does everything. Second causes have no efficiency. The laws of nature are said to be the uniform modes of divine operation. Gravitation does not flow from 
the nature of matter, but is a mode of God's uniform efficiency. What are called chemical affinities are not due to anything in different kinds of matter, but God always acts in one way in connection with an acid, and in another way in connection with an alkali. If a man places a particle of salt or sugar on his tongue, the sensation which he experiences is not to be referred to the salt or sugar, but to God's agency. When this theory is extended, as it generally is by its advocates, from the external to the internal world, the universe of matter and mind, with all their phenomena, is a constant effect of the omnipresent activity of God. The minds of some men, as remarked above, are so constituted that they can pass from the theory that God cloes nothing, to the doctrine that He does everything, without seeing the difference. $\mathrm{Mr}$. Russel Wallace, the companion and peer of Mr. Darwin, devotes a large part of his book on "Natural Selection," to prove that the organs of plants and animals are formed by blind physical causes. Toward the close of the volume he teaches that there are no such causes. He asks the question, What is Matter? and answers, Nothing. We know, he says, nothing but force; and as the only force of which we have any 
immediate knowledge is mind-force, the inference. is " that the whole universe is not merely dependent on, but actually is, the will of higher intelligences, or of one Supreme Intelligence." 1 This is a transition from virtual materialism to idealistic pantheism. The effect of this admission on the part of Mr. Wallace on the theory of natural selection, is what an explosion of its boiler would be to a steamer in mid-ocean, which should blow out its deck, sides, and bottom. Nothing would remain above water.

The Duke of Argyll seems at times inclined to lapse into the same doctrine. "Science," he says, "in the modern doctrine of conservation of energy and the convertibility of forces, is already getting a firm hold of the idea, that all kinds of force are but forms of manifestations of one central force issuing from some one fountain-head of power. Sir John Herschel has not hesitated to say, "that it is but reasonable to regard the force of gravitation as the direct or indirect result of a consciousness or will existing somewhere.' And even if we cannot certainly identify force in all its forms with the direct energies of the one Omnipresent and

1 The Theory of Natural Selection. By Alfred Russel Wallace. London, 1870, p. 368. 
All-pervading Will, it is at least in the highest degree unphilosophical to assert the contrary, to think or to speak, as if the forces of nature were either independent of, or even separate from the Creator's power." 1 The Duke, however, in the general tenor of his book, does not differ from the common doctrine, except in one point. He does not deny the efficiency of physical causes, or resolve them all into the efficiency of God; but he teaches that God, in this world at least, never acts except through those causes. He applies this doctrine even to miracles, which he regards as effects produced by second causes of which we are ignorant, that is, by some higher law of nature. The Scriptures, however, teach that God is not thus bound; that He operates through second causes, with them, or without them, as He sees fit. It is a purely arbitrary assumption, that when Christ raised the dead, healed the lepers, or gave sight to the blind, any second cause intervened between the effect and the efficiency of his will. What physical law, or uniformly acting force, operated to make the axe float at the command of the prophet? or, in

1 Reign of Law. By the Duke of Argyle. Fifth edition, London, 1867, p. 123. 
that greatest of all miracles, the original creation of the world.

\section{Mr. Darwin's Theory.}

We have not forgotten Mr. Darwin. It seemed desirable, in order to understand his theory, to see its relation to other theories of the universe and its phenomena, with which it is more or less connected. His work on the "Origin of Species" does not purport to be philosophical. In this aspect it is very different from the cognate works of Mr. Spencer. Darwin does not speculate on the origin of the universe, on the nature of matter, or of force. $\mathrm{He}$ is simply a naturalist, a careful and laborious observer; skillful in his descriptions, and singularly candid in dealing with the difficulties in the way of his peculiar doctrine. $\mathrm{He}$ set before himself a single problem, namely, How are the fauna and flora of our earth to be accounted for? In the solution of this problem, he assumes :-

1. The existence of matter, although he says little on the subject. Its existence however, as a real entity, is everywhere taken for granted.

2. He assumes the efficiency of physical 
causes, showing no disposition to resolve them into mind-force, or into the efficiency of the First Cause.

3. He assumes also the existence of life in the form of one or more primordial germs. $\mathrm{He}$ loes not adopt the theory of spontaneous generation. What life is he does not attempt to explain, further than to quote (p. 326), with approbation, the definition of Herbert Spencer, who says, "Life depends on, or consists in, the incessant action and reaction of various forces," - which conveys no very definite idea.

4. To account for the existence of matter and life, Mr. Darwin admits a Creator. This is done explicitly and repeatedly. Nothing, however, is said of the nature of the Creator and of his relation to the world, further than is implied in the meaning of the word.

5. From the primordial germ or germs ( $\mathrm{Mr}$. Darwin seems to have settled down to the assumption of only one primordial germ), all living organisms, vegetable and animal, including man, on our globe, through all the stages of its history, have descended.

6. As growth, organization, and reproduction are the functions of physical life, as soon as 
the primordial germ began to live, it began to grow, to fashion organs however simple, for its nourishment and increase, and for the reproduction, in some way, of living forms like itself. How all living things on earth, including the endless variety of plants, and all the diversity of animals - insects, fishes, birds, the ichthyosaurus, the mastodon, the mammoth, and man - have descended from the primordial animalcule, he thinks, may be accounted for by the operation of the following natural laws, viz. : -

First, the law of Heredity, or that by which like begets like. The offspring are like the parent.

Second, the law of Variation, that is, while the offspring are, in all essential characteristics, like their immediate progenitor, they nevertheless vary more or less within narrow limits, from their parent and from each other. Some of these variations are indifferent, some deteriorations, some improvements, that is, they are such as enable the plant or animal to exercise its functions to greater advantage.

Third, the law of Over Production. All plants and animals tend to increase in a geometrical ratio; and therefore tend to overrun 
enormously the means of support. If all the seeds of a plant, all the spawn of a fish, were to arrive at maturity, in a very short time the world could not contain them. Hence of necessity arises a struggle for life. Only a few of the myriads born can possibly live.

Fourth, here comes in the law of Natural Selection, or the Survival of the Fittest. That is, if any individual of a given species of plant or animal happens to have a slight deviation from the normal type, favorable to its success in the struggle for life, it will survive. This variation, by the law of heredity, will be transmitted to its offspring, and by them again to theirs. Soon these fuvored ones gain the ascendency, and the less favored perish; and the modification becomes established in the species. After a time another and another of such favorable variations occur, with like results. Thus very gradually, great changes of structure are introduced, and not only species, but genera, families, and orders in the vegetable and animal world, are produced. Mr. Darwin says he can set no limit to the changes of structure, habits, instincts, and intelligence, which these simple laws in the course of millions or milliards of centuries may bring into 
existence. He says, "we cannot comprehend what the figures $60,000,000$ really imply, and during this, or perhaps a longer roll of years, the land and waters have everywhere teemed with living creatures, all exposed to the struggle for life, and undergoing change." (p. 354). "Mr. Croll," he tells us, "estimates that about sixty millions of years have elapsed since the Cambrian period, but this, judging from the small amount of organic change since the commencement of the glacial period, seems a very short time for the many and the great mutations of life, which have certainly occurred since the Cambrian formation; and the previous one hundred and forty million years can hardly be considered as sufficient for the development of the varied forms of life which certainly existed toward the close of the Cambrian period." (p. 379). Years in this connection have no meaning. We might as well try to give the distance of the fixed stars in inches. As astronomers are obliged to take the diameter of the earth's orbit as the unit of space, so Darwinians are obliged to take a geological cycle as their unit of duration. 


\section{Natural Selection.}

As Natural Selection which works so slowly is a main element in Mr. Darwin's theory, it is necessary to understand distinctly what he means by it. On this point he leaves us no room for doubt. On p. 92, he says: "This preservation of favorable variations, and the destruction of injurious variations, I call Natural Selection, or, the Survival of the Fittest." "Owing to the struggle (for life) variations, however slight and from whatever cause proceeding, if they be in any degree profitable to the individuals of a species, in their infinitely complex relations to other organic beings and to their physical conditions of life, will tend to the preservation of such individuals, and will generally be inherited by their offspring. The offspring also will thus have a better chance of surviving, for, of the many individuals of any species which are periodically born, but a small number can survive. I have called this principle, by which each slight variation, if useful, is preserved, by the term Natural Selection, in order to mark its relation to man's power of selection. But the expression often used by Mr. Herbert Spencer of the Survival of the Fit- 
test, is more accurate, and sometimes is equally convenient." (p. T2). "Slow though the progress of selection may be, if feeble man can do so much by artificial selection, I can see no limit to the amount of change, to the beauty and infinite complexity of the co-adaptations between all organic beings, one with another; and with their physical conditions of life, which may be effected in the long course of time by nature's power of selection, or the survival of the fittest." (p. 125). "It may be objected that if organic beings thus tend to rise in the scale, how is it that throughout the world a multitude of the lowest forms still exist; and how is it that in each great class some forms are far more highly developed than others? . . . . On our theory the continuous existence of lowly forms offers no difficulty; for natural selection, or the survival of the fittest, does not necessarily include progressive development, it only takes advantage of such variations as arise and are beneficial to each creature under its complex relations of life. . . . Geology tells us that some of the lowest forms, the infusoria and rhizopods, have remained for an enormous period in nearly their present state." (p. 145). "The fact of little or no modifica- 
tion having been effected since the glacial period would be of some avail against those who believe in an innate and necessary law of development, but is powerless against the doctrine of natural selection, or the survival of the fittest, which implies only that variations or individual differences of a favorable nature occasionally arise in a few species and are then preserved." (p. 149)

This process of improvement under the law of natural selection includes not only chancés in the organic structure of animals, but also in their instincts and intelligence. On entering on this part of his subject, Mr. Darwin says, "I would premise that I have nothing to do with the origin of the primary mental powers, any more than I have with that of life itself. We are concerned only with the diversities of instinct and of other mental qualities within the same class." (p. 255) He shows that even in a state of nature the instincts of animals of the same species do in some degree vary, and that they are transmitted by inheritance. A mastiff has imparted courage to a greyhound, and a greyhound has transmitted to a shepherd-dog a disposition to hunt hares. Among sporting dogs, the young of the pointer or retriever 
have been known "to point or to retrieve without instruction. "If," he says, "it can be shown that instincts do vary ever so little, then I can see no difficulty in natural selection preserving and continually accumulating variations of instinct to any extent that was profitable. It is thus, as I believe, that all the most complex and wonderful instincts have arisen." (p. 257) He was rather unguarded in saying that he saw no difficulty in accounting for the most wonderful instincts of animals. He admits that he has found very great difficulty. He selects three cases which he found it specially hard to deal with: that of the cuckoo, that of the cell-building bee, and of the slavemaking ant. He devotes much space and labor in endeavoring to show how the instinct of the bee, for example, in the construction of its cell, might have bẻen gradually acquired. It is clear, however, that he was not able fully to satisfy even his own mind; for he admits that " it will be thought that I have an overweening confidence in the principle of natural selection, when I do not admit that such wonderful and well established facts do not annihilate the theory." (p. 290) This remark was made with special reference to the instincts 
of the ant, which he finds very hard to account for. He adds, "No doubt many instincts of very difficult explanation could be opposed to the theory of natural selection: cases in which we cannot see how an instinct could possibly have originated; cases in which no intermediate gradations are known to exist; cases of instinct of such trifling importance that they could hardly have been acted upon by natural selection; cases of instincts almost identically the same in animals so remote in the scale of nature, that we cannot account for their similarity by inheritance from a common progenitor, and consequently cannot believe that they were independently acquired through natural selection. I will not here enter on those cases, but will confine myself to one special difficulty which at first appeared to me insuperable, and actually fatal to the whole theory. I allude to neuters, or sterile females in insect communities; for these neuters often differ widely in instinct and structure from both the males and the fertile females, and yet, from being sterile, they cannot propagate their kind." (p.289) He is candid enough to say, in conclusion, "I do not pretend that the facts given in this chapter (on instinct) strengthen 
in any great degree my theory; but none of the cases of difficulty, to the best of my judgment, annihilate it." (p.297) When it is remembered that his theory is, that slight variations occurring in an individual advantageous to it (not to its associates), in the struggle for life, is perpetuated by inheritance, it is no wonder that the case of sterile ants gave him so much trouble. Accidental sterility is not favorable to the individual, and its being made permanent by inheritance, is out of the question, for the sterile have no descendants. Yet these sterile females are not degenerations, they are in general larger and more robust than their associates.

We have thus seen that, according to Mr. Darwin, all the infinite variety of structure in plants and animals is due to the law of natural selection. "On the principle of natural selection with divergence of character," he says, "it does not seem incredible that, from some such low and intermediate form, both animals and plants have been developed, and if we admit this, we must likewise admit that all the organized beings which have ever lived on this earth may be descended from some one primordial form." (p. 573) We have seen also 
that he does not confine his theory to organic structure, but applies it to all the instincts and all the forms of intelligence manifested by irrational creatures. Nor does he stop there; he includes man within the sweep of the same law. "In the distant future I see open fields for far more important researches. Psychology will be based on a new foundation, that of the necessary acquirement of each mental power and capacity by gradation. Light will be thrown on the origin of man and his history." (p. 577)

The "distant future" was near at hand. In his introduction to his work on the "Descent of Man," he says, he had determined not to publish on that subject, "as I thought that I should thus only add to the prejudices against my views. It seemed to me sufficient to indicate, in the first edition of my 'Origin of Species,' that by this work 'light would be thrown on the origin of man and his history ;' and this implies that man must be included with other organic beings in any general conclusion respecting his manner of appearance on this earth. Now the case wears a wholly different aspect. When a naturalist like Carl Vogt (we shall see in what follows what kind 
of a witness he is) ventures to say in his address as President of the National Institution of Geneva (1869), 'Personne, en Europe au moins, n'ose plus soutenir la création indépendante et de toutes piéces, des espéces, - it is manifest that at least a large number of naturalists must admit that species are the modified descendants of other species; and this especially holds good of the younger and rising naturalists. ... . Of the older and honored chiefs in natural science, many unfortunately are still opposed to evolution in every form." Carl Vogt would not write thus. To him no man is honored who does agree with him, and any man who believes in God he execrates.

In 1871, Mr. Darwin ventured on the publication of his "Descent of Man." In that work, he endeavors to show that the proximate progenitor of man is the ape. He says "there is less difference of structure between the two, than between the higher and lower forms of apes themselves." Not only so, but he attempts to show that the mental faculties of man are derived by slight variations, long continued, from the measure of intellect possessed by lower animals. He even says, that there is less difference in intelligence between man and 
the higher mammals, than there is between the intelligence of the ant and that of the coccus, insects of the same class. ${ }^{1}$

In like manner he teaches that man's moral nature has been evolved by slow degrees from the social instincts common to many animals. (pp. 68, 94) The moral element, thus derived, he admits might lead to very different lines of conduct. "If men," he says, "were reared under the same conditions as hives-bees, there can hardly be a doubt, that our unmarried females would, like the worker-bees, think it a sacred duty to kill all their brothers, and mothers would strive to kill their fertile daughters; and no one would think of interfering. (vol. i. p. 70)

"Lower animals, especially the dog, manifest love, reverence, fidelity, and obedience; and it is from these elements that the religious sentiment in man has been slowly evolved by a process of natural selection." (vol. i. p. 65)

The grand conclusion is, "man (body, soul, and spirit) is descended from a hairy quadruped, furnished with a tail and pointed ears, probably arboreal in its habits, and an inhab-

1 Descent of Man, etc. By Charles Darwin, M. A., F. R. S. etc. New York, 1871, vol. i. p. 179. 
itant of the Old World." (vol. ii. p. 372) Mr. Darwin adds: "He who denounces these views (as irreligious) is bound to explain why it is more irreligious to explain the origin of man as a distinct species by descent from some lower form, through the laws of variation and natural selection, than to explain the birth of the individual through the laws of ordinary reproduction." (vol. ii. p. 378)

\section{The Sense in which Mr. Darwin uses the Word "Natural."}

We have not yet reached the heart of $\mathrm{Mr}$. Darwin's theory. The main idea of his system lies in the word "natural." He uses that word in two senses: first, as antithetical to the word artificial. Men can produce very marked varietios as to structure and habits of animals. This is exemplified in the production of the different breeds of horses, cattle, sheep, and dogs ; and specially, as $\mathrm{Mr}$. Darwin seems to think, in the case of pigeons. Of these, he says, "The diversity of breeds is something astonishing." Some have long, and some very short bills; some have large feet, some small; some long necks, others long wings and tails, while others have singularly short tails; some have thirty, 
and even forty, tail-feathers, instead of the normal number of twelve or fourteen. They differ as much in instinct as they do in form. Some are carriers, some pouters, some tumblers, some trumpeters; and yet all are descendants of the Rock Pigeon which is still extant. If, then, he argues, man, in a comparatively short time, has by artificial selection produced all these varieties, what might be accomplished on the boundless scale of nature, during the measureless ages of the geologic periods.

Secondly, he uses the word natural as antithetical to supernatural. Natural selection is a selection made by natural laws, working without intention and design. It is, therefore, opposed not only to artificial selection, which is made by the wisdom and skill of man to accomplish a given purpose, but also to supernatural selection, which means either a selection originally intended by a power higher than nature; or which is carried out by such power. In using the expression Natural Selection, Mr. Darwin intends to exclude design, or final causes. All the changes in structure, instinct, or intelligence, in the plants or animals, including man, descended from the primordial germ, 
or animalcule, have been brought about by unintelligent physical causes. On this point he leaves us in no doubt. He defines nature to be "the aggregate action and product of natural laws; and laws are the sequence of events as ascertained by us." It had been objected that he often uses teleological language, speaking of purpose, intention, contrivance, adaptation, etc. In answer to this objection, he says: "It has been said, that I speak of natural selection as a power or deity; but who objects to an author speaking of the attraction of gravity as ruling the morements of the planet?" He admits that in the literal sense of the words, natural selection is a false term; but "who ever objected to chemists, speaking of the elective affinities of various elements? - and yet an acid cannot strictly be said to elect the base with which it in preference combines." (p. 93) We have here an affirmation and a negation. It is affirmed that natural selection is the operation of natural laws, analogous to the action of gravitation and of chemical affinities. It is denied that it is a process originally designed, or guided by intelligence, such as the activity which foresees an end and consciously selects and controls the means of its accomplishment. 
Artificial selection, then, is an intelligent process; natural selection is not.

There are in the animal and vegetable worlds innumerable instances of at least apparent contrivance, which have excited the admiration of men in all ages. There are three ways of accounting for them. The first is the Scriptural doctrine, namely, that God is a Spirit, a personal, self-conscious, intelligent agent; that $\mathrm{He}$ is is infinite, eternal, and unchangeable in his being and perfections; that $\mathrm{He}$ is ever present; that this presence is a presence of knowledge and power. In the external world there is always and everywhere indisputable evidence of the activity of two kinds of force : the one physical, the other mental. The physical belongs to matter, and is due to the properties with which it has been endowed; the other is the everywhere present and ever acting mind of God. To the latter are to be referred all the manifestations of design in nature, and the ordering of events in Providence. This doctrine does not ignore the efficiency of second causes ; it simply asserts that God overrules and controls them. Thus the Psalmist says, "I am fearfully and wonderfully made. ... My substance was not hid from thee, when 
I was made in secret, and curiously wrought (or embroidered) in the lower parts of the earth. Thine eyes did see my substance yet being imperfect; and in thy book all my members were written, which in continuance were fashioned, when as yet there were none of them." " $\mathrm{He}$ who fashioned the eye, shall not He see? He that formed the ear shall not He hear?" "God makes the grass to grow, and herbs for the children of men." He sends rain, frost, and snow. He controls the winds and the waves. IIe determines the casting of the lot, the flight of an arrow, and the falling of a sparrow. This universal and constant control of God is not only one of the most patent and pervading doctrines of the Bible, but it is one of the fundamental principles of even natural religion.

The second method of accounting for contrivances in nature admits that they were foreseen and purposed by God, and that He endowed matter with forces which He foresaw and intended should produce such results. But here his agency stops. He never interferes to guide the operation of physical causes. $\mathrm{He}$ does nothing to control the course of nature, or the events of history. On this theory it may be said,(1.) That it is utterly inconsistent with the 
Scriptures. (2.) It does not meet the religious and moral necessities of our nature. It renders prayer irrational and inoperative. It makes it vain for a man in any emergency to look to God for help. (3.) It is inconsistent with obvious facts. We see around us innumerable evidences of the constant activity of mind. This evidence of mind and of its operations, according to Lord Brougham and Dr. Whewell, is far more clear than that of the existence of matter and of its forces. If one or the other is to be denied, it is the latter rather than the former. Paley indeed says, that if the construction of a watch be an undeniable evidence of design it would be a still more wonderful manifestation of skill, if a watch could be be made to produce other watches; and, it may be added, not only other watches, but all kinds of time-pieces in endless variety. So it has been asked, if man can make a telescope, why cannot God make a telescope which produces others like itself? This is simply asking, whether matter can be made to do the work of mind? The idea involves a contradiction. For a telescope to make a telescope, supposes it to select copper and zinc in due proportions and fuse them into brass; to fashion that brass 
into inter-entering tubes; to collect and combine the requisite materials for the different kinds of glass needed; to melt them, grind, fashion, and polish them; adjust their densities and focal distances, etc., etc. A man who can believe that brass can do all this, might as well believe in God. The most credulous men in the world are unbelievers. The great Napoleon could not believe in Providence; but he believed in his star, and in lucky and unlucky days.

This banishing God from the world is simply intolerable, and, blessed be his name, impossible. An absent God who does nothing is, to us, no God. Christ brings God constantly near to us. He said to his disciples, "Consider the ravens, for they neither sow nor reap; which have neither store-house nor barn; and God feedeth them; how much better are ye than the fowls. And which of you by taking thought can add to his stature one cubit? Consider the lilies how they grow; they toil not, neither do they spin; and yet I say unto you that Solomon in all his glory was not arrayed like one of these. If then God so clothe the grass, which is to-day in the field, and to-morrow is cast into the oven; how much 
more will He clothe you, O ye of little faith." "And seek ye not what ye shall eat, or what ye shall drink, neither be ye of doubtful mind. For all these things do the nations of the world seek after; and your Father knoweth that ye have need of these things." It may be said that Christ did not teach science. True, but He taught truth; and science, so called, when it comes in conflict with truth, is what man is when he comes in conflict with God.

The advocates of these extreme opinions protest against being considered irreligious. Herbert Spencer says, that his doctrine of an inscrutable, unintelligent, unknown force, as the cause of all things, is a much more religious doctrine than that of a personal, intelligent, and voluntary Being of infinite power and goodness. Matthew Arnold holds that an unconscious "porver which makes for right," is a higher idea of God than the Jehovah of the Bible. Christ says, God is a Spirit. Holbach thought that he made a great advance on that definition, when he said, God is motion.

The third method of accounting for the contrivances manifested in the organs of plants and animals, is that which refers them to the blind operation of natural causes. They are 
not due to the continued coöperation and control of the divine mind, nor to the original purpose of God in the constitution of the universe. This is the doctrine of the Materialists, and to this doctrine, we are sorry to say, Mr. Darwin, although himself a theist, has given in his adhesion. It is on this account the Materialists almost deify him.

From what has been said, it appears that Darwinism includes three distinct elements. First, evolution; or the assumption that all organic forms, vegretable and animal, have been evolved or developed from one, or a few, primordial living germs; second, that this evolution has been effected by natural selection, or the survival of the fittest; and third, and by far the most important and only distinctive element of his theory, that this natural selection is without design, being conducted by unintelligent pliysical causes. Neither the first nor the second of these elements constitute Darwinism; nor do the two combined. As to the first, namely, evolution, Mr. Darwin himself, in the historical sketch prefixed to the fifth edition of his "Origin of Species," says, that Lamarck, in 1811 and more fully in 1815, "taught that all species, including man, are 
descended from other species." He refers to some six or eight other scientists, as teaching the same doctrine. This idea of Evolution was prominently presented and elaborated in the "Vestiges of Creation," first published in 1844. Ulrici, Professor in the University of Halle, Germany, in his work "Gott und die Natur," says that the doctrine of evolution took no hold on the minds of scientific men, but was positively rejected by the most eminent physiologists, anong whom he mentions J. Müller, R. Wagner, Bischoff, Hoffmann, and others. ${ }^{1} \quad$ The Rev. George Henslow, Lecturer on Botany at St. Bartholomew's Hospital, London, himself a pronounced "evolutionist, says the theories of Lamarck and of the "Vestiges of Creation" have given place to that of Mr. Darwin; "and there are not wanting many symptoms of decay in the acceptance even of his. Not only has he considerably modified his views in later editions of the ' Origin of Species,' distinctly expressing the opinion that he attributed too great influence to natural selection, but even men of science, Owen, Huxley, - and at least in its application

1 Golt und die Natur. Von D. Hermann Ulrici. Zweite Aufage. Leipzig, 1866, p. 394. 
to man, Wallace himself, - are either opposed to it in great measure, or else give it but a qualified assent. Thus, it has been the fate of all theories of the development of living things to lapse into oblivion. Evolution itself, however, will stand the same." 1 We find in the "Transactions of the Victoria Institute," a still more decided repudiation of Darwinism on the part of Mr. Henslow. He there says: "I do not believe in Darwin's theory; and have endeavored to refute it by showing its utter impossibility." 2 He defines Evolution by saying, "It supposes all animals and plants that exist now, or have ever existed, to have been produced through laws of generation from preēxisting animals and plants respectively; that affinity amongst organic beings implies, or is due to community of descent; and that the degree of affinity between organisms is in proportion to their nearness of generation, or, at least, to the persistence of common characters, they being the products of originally the same parentage." 3 A man, therefore, may be an

1 The Theory of Evolution of Living Things and the Application of the Principles of Evolution to Religion. By Rev. George Henslow, M. A., F. L. S., F. G. S. London, 1873, pp. 27, 28.

2 Journal of the Transactions of the Victoria Institute, or Philosophical Society of Great Britain. Vol. iv. London, 1870, p. 278.

${ }^{8}$ Evolution and Religion, p. 29. 
evolutionist, without being a Darwinian. It should be mentioned that Mr. Henslow expressly excludes man, both as to body and soul, from the law of evolution.

Nor is the theory of natural selection the vital principle of Mr. Darwin's theory, unless the word natural be taken in a sense antithetical to supernatural. In the historical sketch just referred to, Mr. Darwin not only says that he had been anticipated in teaching the doctrine of Evolution by Lamarck and the author of the "Vestiges of Creation;" but that the theory of natural selection, as the means of accounting for evolution, was not original with him. He tells us that as early as 1813 , Dr. W. C. Wells "distinctly recognizes the principle of natural selection ;" and that Mr. Patrick Matthew, in 1831, "gives precisely the same view of the origin of species as that propounded by Mr. Wallace and myself." Ideas are like seed: they are often cast forth, and not finding a congenial soil produce no fruit. To Mr. Darwin is undoubtedly due the elaboration and thoroughly scientific defence of the theory of natural selection, and to him is to be referred the deep and widespread interest which it has excited. 


\section{Darwinism excludes Teleology.}

It is however neither evolution nor natural selection, which give Darwinism its peculiar character and importance. It is that Darwin rejects all teleology, or the doctrine of final causes. He denies design in any of the organisms in the vegetable or animal world. $\mathrm{He}$ teaches that the eye was formed without any purpose of producing an organ of vision.

Although evidence on this point has already been adduced, yet as it is often overlooked, at least in this country, so that many men speak favorably of Mr. Darwin's theory, who are no more Darwinians than they are Mussulmans; and as it is this feature of his system which brings it into conflict not only with Christianity, but with the fundamental principles of natural religion, it should be clearly established. The sources of proof on this point are, -1 st. Mr. Darwin's own writings. 2d. The expositions of his theory given by its advocates. 3d. The character of the objections urged by its opponents.

The point to be proved is that it is the distinctive doctrine of $\mathrm{Mr}$. Darwin, that species owe their origin, not to the original intention 
of the divine mind; not to special acts of creation calling new forms into existence at certain epochs; not to the constant and everywhere operative efficiency of God, guiding physical causes in the production of intended effects; but to the gradual accumulation of unintended variations of structure and instinct, securing some advantage to their subjects.

\section{Darwin's own Testimony.}

That such is $\mathrm{Mr}$. Darwin's doctrine we prove from his own writings. And the first proof from that source is found in express declarations. When an idea pervades a book and constitutes its character, detached passages constitute a very small part of the evidence of its being inculcated. In the present case, however, such passages are sufficient to satisfy even those who have not had occasion to read Mr. Darwin's books. In referring to the similarity of structure in animals of the same class, he says, "Nothing can be more hopeless than to attempt to explain this similarity of pattern in members of the same class, by utility or the doctrine of final causes." 1

On the last page of his work, he says: "It 
is interesting to contemplate a tangled bank, clothed with many plants of many kinds, with birds singing on the bushes, with various insects flitting about, and with worms crawling through the damp earth, and to reflect that these elaborately constructed forms, so different from each other, and dependent on each other in so complex a manner, have all been produced by laws acting around us. These laws, taken in the largest sense, being growth with reproduction; variability from the indirect and direct action of the conditions of life, and from use and disuse; a ratio of increase so high as to lead to a struggle for life, and as a consequence to natural selection, entailing divergence of character and extinction of less improved forms. Thus from the war of nature, from famine and death, the most exalted object which we are capable of conceiving, the production of the higher animals directly follows. There is a grandeur in this view of life, with its several powers, having been originally breathed by the Creator into a few forms or into one; and that whilst this planet has gone cycling on according to the fixed law of gravity, from so simple a beginning endless forms most beautiful and most wonderful have been, and are being evolved." (p. 579) 
In another of his works, he asks, "Did $\mathrm{He}$ (God) ordain that crop and tail-feathers of the pigeon should vary, in order that the fancier might make his grotesque pouter and fan-tail breeds? Did He cause the frame and mental qualities of the dog to vary, in order that a breed might be formed of indomitable ferocity, with jaws fitted to pin down the bull, for man's brutal sport? But if we give up the principle in one case ; if we do not admit that the variations of the primeval dog were intentionally guided in order, for instance, that the greyhound, that perfect image of symmetry and vigor, might be formed; no shadow of reason can be assigned for the belief that variations, alike in nature and the results of the same general laws, which have been the groundwork through natural selection of the most perfectly adapted animals in the world, man included, were intentionally and specially guided. However much we may wish it, we can hardly follow Professor Asa Gray, in his belief 'that variations have been led along certain beneficial lines, as a stream is led along useful lines of irrigation." " 1

1 The Variations of Animals and Plants under Domestication. By Charles Darwin, F. R. S., ete. New York, 1868, vol. ii. pp. 515,516 . 
Variations, which by their gradual accumulation give rise to new species, genera, families, and orders, are themselves, step by step, accidental. Mr. Darwin sometines says they happen by chance; sometimes he says they happen of necessity; at others he says, "We are profoundly ignorant of their causes." These are only different ways of saying that they are not intentional. When a man lets anything fall from his hands, and says it was accidental, he does not mean that it was causeless, he only means that it was not intentional. And that is precisely what Darwin means when he says that species arise out of accidental variations. His whole book is an argument against teleology. The whole question is, How are we to account for the innumerable varieties, kinds, and genera of plants and animals, including man? Were they intended? or, Did they arise from the gradual accumulations of unintentional variations? His answer to these questions is plain. On page 245, he says: "Nothing at first can appear more difficult to believe than that the more complex organs and instincts have been perfected not by means superior to, though analogous with, human reason, but by innumerable slight variations, each good 
for the individual possessor. Nevertheless, this difficulty, though appearing to our imagination ${ }^{1}$ insuperably great, cannot be considered real, if we admit the following propositions, namely, that all parts of the organizations and instincts offer, at least, individual differences; that there is a struggle for existence, which leads to the preservation of profitable deriations of structure or instinct; and, lastly, that gradations in the state of perfection of each organ may have existed, each good of its kind." He says, over and over, that if beauty or any variation of structure can be shown to be intended, it would "annihilate his theory." His doctrine is that such unintended variations, which happen to be useful in the struggle for life, are preserved, on the principle of the survival of the fittest. He urges the usual objections to teleology derived from undeveloped or useless organs, as web-feet in the upland goose and frigate-bird, which never swim.

What, however, perhaps more than anything, makes clear his rejection of design is the manner in which he deals with the complicated or-

1 What can the word "imagination" mean in this sentence, if it does not mean "Common Sense?" 
gans of plants and animals. Wliy don't he say, they are the product of the divine intelligence? If God made them, it makes no difference, so far as the question of design is concerned, how He made them: whether at once or by a process of evolution. But instead of referring them to the purpose of God, he laboriously endeavors to prove that they may be accounted for without any design or purpose whatever.

"To suppose," he says, "that the eye with all its inimitable contrivances for adjusting the focus to different distances, for admitting different degrees of light, and for the correction of spherical and chromatic aberration, could have been formed by natural selection, seems, I freely confess, absurd in the highest degree." (p. 222) Nevertheless he attempts to explain the process. "It is scarcely possible," he says, " to avoid comparing the eye with the telescope. We know that this instrument has been perfected by the long continued efforts of the highest of human intellects; and we naturally infer that the eye has been formed by a somewhat analogous process. But may not this inference be presumptuous? Have we any right to assume that the Creator works by intellectual powers like those of man? If we must compare 
the eye to an optical instrument, we ought in imagination to take a thick layer of transparent tissue, with spaces filled with fluid, and with a nerve sensitive to light beneath, and then suppose every part of this layer to be continually changing slowly in density, so as to separate into layers of different densities and thicknesses, placed at different distances from each other, and with the surfaces of each layer slowly changing in form. Further, we must suppose that there is a power represented by natural selection, or the survival of the fittest, always intently watching each slight alteration in the transparent layers, and carefully preserving each, which, under varied circumstances, tends to produce a distinct image. We must suppose each new state of the instrument to be multiplied by the million; each to be preserved until a better is produced, and the old ones to be all destroyed. In living bodies, variations will cause the slight alterations, generation will multiply them almost infinitely, and natural selection will pick out with unerring skill each improvement." 1 (p. 226) "Let this process,

$1 \mathrm{Mr}$. Darwin's habit of personifying nature has given, as his friend Mr. Wallaee says, his readers a good deal of trouble. He defines nature to be the aggregate of physical forees; and in 
he says, "go on for millions of years," and we shall at last have a perfect eye.

It would be absurd to say anything disrespectful of such a man as Mr. Darwin, and scarcely less absurd to indulge in any mere extravagance of language; yet we are expressing our own experience, when we say that we regard Mr. Darwin's books the best refutation of Mr. Darwin's theory. He constantly shuts us up to the alternative of believing that the eye is a work of design or the product of the unintended action of blind physical causes. To any ordinarily constituted mind, it is absolutely impossible to believe that it is not a work of design. Darwin himself, it is evident, dear as his theory is, can hardly believe it. "It is indispensable," he says, "to arrive at a just conclusion as to the formation of the eye, that the reason should conquer the imagination; but I have felt the difficulty far too keenly to be surprised at any degree of hesitation in extending the principle of natural selection to so startling an extent." (p. 225)

the single passage quoted, he speaks of Natural Selection "as intently watehing" "picking out with unerring skill," and "carefully preserving." It is true, he tells us this is all to be understood metaphorically. 
It will be observed that every step in his account of the formation of the eye is an arbitrary assumption. We must first assume.a thick layer of tissue; then that the tissue is transparent; then that it has cavities filled with fluid; that beneath the tissue is a nerve sensitive to light; then that the fluid is constantly varying in density and thickness; that its surfaces are constantly changing their contour; that its different portions are ever shifting their relative distances; that every favorable change is seized upon and rendered permanent, - thus after millions of year's we may get an eye as perfect as that of an eagle. In like manner we may suppose a man to sit down to account for the origin and contents of the Bible, assuming as his "working hypothesis," that it is not the product of mind either human or divine, but that it was made by a typesetting machine worked by steam, and picking out type hap-hazard. In this way in a thousand years one sentence might be produced, in another thousand a second, and in ten thousand more, the two might get together in the right position. Thus in the course of "millions of years" the Bible might have been produced, with all its historical details, all its elevated 
truths, all its devout and sublime poetry, and above all with the delineation of the character

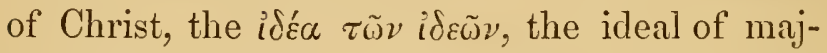
esty and loveliness, before which the whole world, believing and unbelieviug, perforce bows down in reverence. And when reason has sufficiently subdued the imagination to admit all this, then by the same theory we may account for all the books in all languages in all the libraries in the world. Thus we should have Darwinism applied in the sphere of literature. This is the theory which we are told is to sweep away Christianity and the Church!

Mr. Darwin gives the same unsatisfactory account of the marvellous "contrivances" in the vegetable world. In one species of Orchids, the labellum or lower lip is hollowed into a great bucket continually filled with water, secreted from two horns which stand above it; when the bucket is sufficiently filled, the water flows out through a pipe or spout on one side. The bees, which crowd into the flower for sake of the nectar, jostle each other, so that some fall into the water; and their wings becoming wet they are unable to fly, and are obliged to crawl through the spout. In doing this they 
come in contact with the pollen, which, adhering to their backs, is carried off to other flowers. This complicated contrivance by which the female plants are fertilized has, according to the theory, been brought about by the slow process of natural selection or survival of the fittest.

Still more wonderful is the arrangement in another species of Orchids. When the bee begins to gnaw the labellum, he unavoidably touches a tapering projection, which, when touched, transmits a vibration which ruptures a membrane, which sets free a spring by which a mass of pollen is shot, with unerring aim, over the back of the bee, who then departs on his errand of fertilization.

A very large class of plants are fertilized by means of insects. These flowers are beautiful, not for the sake of beauty, - for that Mr. Darwin says would annihilate his theory, - but those which happen to be beantiful attract insects, and thus become fertilized and perpetuated, while the plainer ones are neglected and perish. So with regard to birds. The females are generally plain, because those of bright colors are so exposed during the period of incubation that they are destroyed by their enemies. 
In like manner male birds are usually adorned with brilliant plumage. This is accounted for on the ground that they are more attractive, and thus they propagate their race, while the plainer ones have few or no descendants. Thus all design is studiously and laboriously excluded from every department of nature.

The preceding pages contain only a small part of the evidence furnished by Mr. Darwin's own writings, that his doctrine involves the denial of all final causes. The whole drift of his books is to prove that all the organs of plants and animals, all their instincts and mental endowments, may be accounted for by the blind operation of natural causes, without any intention, purpose, or coüperation of God. This is what Professor Huxley and others call "the creative idea," to which the widespread influence of his writings is to be referred.

Testimony of the Advocates of the Theory.

It is time to turn to the exposition of Darwinism by its avowed advocates, in proof of the assertion that it excludes all teleology.

The first of these witnesses is Mr. Alfred Russel Wallace, himself a distinguished naturalist. Mr. Darwin informs his readers that as 
early as 1844, he had collected his material and worked out his theory, but had not published it to the world, although it had been communicated to some of his friends. In 1858 he received a memoir from Mr. Wallace, who was then studying the natural history of the Malay Archipelago. From that memoir he learnt that Mr. Wallace had " arrived at almost exactly the same conclusions as I (he himself) have on the origin of species." This led to the publishing his book on that subject contemporaneously with Mr. Wallace's memoir. There has been no jealousy or rivalry between these gentlemen. Mr. Wallace gracefully acknowledges the priority of Mr. Darwin's claim, and attributes to him the credit of having elaborated and sustained it in a way to secure for it universal attention. These facts are mentioned in order to show the competency of Mr. Wallace as a witness as to the true character of Darwinism.

Mr. Wallace, in "The Theory of Natural Selection," devotes a chapter to the consideration of the objections urged by the Duke of Argyll, in his work on the "Reign of Law," against that theory. Those objections are principally two: first, that design necessarily implies an 
intelligent designer; and second, that beauty not being an advantage to its possessor in the struggle for life, cannot be accounted for on the principle of the survival of the fittest. The Duke, he says, maintains that contrivance and beauty indicate "the constant supervision and interference of the Creator, and camnot possibly be explained by the unassisted action of any combination of laws. Now, Mr. Darwin's work," he adds, "has for its main object to show that all the phenomena of living things - all their wonderful organs and complicated structures, their infinite variety of form, size, and color, their intricate and involved relations to each other - may have been produced by the action of a few general laws of the simplest kind, laws which are in most cases mere statements of admitted facts." (p. 265) Those laws are those with which we are familiar: Heredity, Variations, Over Próduction, Struggle for Life, Survival of the Fittest. "It is probable," he says, "that these primary facts or laws are but results of the very nature of life, and of the essential properties of organized and unorganized matter. Mr. Herbert Spencer, in his 'First Principles' and in his 'Biology', has, I think, made us able to understand how this may 
be; but at present we may accept these simple laws, without going further back, and the question then is, Whether the variety, the harmony, the contrivance, and the beauty we perceive, cain have been produced by the action of these laws alone, or whether we are required to believe in the incessant interference and direct action of the mind and will of the Creator." (p. $267)^{1}$ Mr. Wallace says, that the Duke of Argyll maintains that God "has personally applied general laws to produce effects which those laws are not in themselves capable of producing; that the universe alone with all its laws intact, would be a sort of chaos, without variety, without harmony, without design, without beauty; that there is not (and therefore we may presume that there could not be) any self-developing power in the universe. I believe, on the contrary, that the universe is so constituted as to be self-regulating; that as long it contains life, the forms under which

1 The question is not, as Mr. Wallace says, "Ilow has the Creator worked?" but it is, as he himself states, whether the essential properties of matter have alone worked out all the wonders of ereation; or, whether they are to be referred to the mind and will of God. It is wortlyy of remark how Messrs. Darwin and Wallace refer to Mr. Spencer as their philosopher. We have seen what Spencer's philosophy is. 
that life is manifested have an inherent power of adjustment to each other and to their surroundings; and that this adjustment necessarily leads to the greatest amount of variety and beauty and enjoyment, because it does depend on general laws, and not on a continual supervision and rearrangement of details." (p. 268) "The strange springs and traps and pitfalls found in the flowers of Orchids, cannot," he says, "be necessary per se, since exactly the same end is gained in ten thousand other flowers which do not possess them. Is it not then an extraordinary idea, to imagine the Creator of the universe contriving the various complicated parts of these flowers, as a mechanic might contrive an ingenious toy or a difficult puzzle ? Is it not a more worthy conception, that they are the results of those general laws which were so coördinated at the first introduction of life upon the earth as to result necessarily in the utmost possible development of varied forms." (p. 270) "I for one," he says, "cannot believe that the world would come to chaos if left to law alone. . . . . If any modification of structure could be the result of law, why not all? If some self-adaptations should arise, why not others? If any varieties of color, why not all 
the varieties we see? No attempt is made to explain this except by reference to the fact that 'purpose' and 'contrivance' are everywhere visible, and by an illogical deduction they could only have arisen by the direct action of some mind, because the direct action of our minds produce similar 'contrivances;' but it is forgotten that adaptation, however produced, must have the appearance of design." (p. 280) ${ }^{1} \quad$ After referring to the fact that florists and breeders can produce varieties in plants and animals, so that, "whether they wanted a bull-dog to torture another animal, a greyhound to catch a hare, or a bloodhound to hunt down their oppressed fellow-creatures, the required variations have always appeared," he adds: "To be consistent, our opponents must maintain that every one of the variations that have rendered possible the changes produced by man, have been determined at the right time and place by the Creator. Every race produced by the florist or breeder, the dog or the pigeon fancier, the rat-catcher, the sporting man, or the slave-hunter, must have been provided for by varieties occurring when

${ }^{1}$ It is, therefore, clear that design is what MIr. Darwin and Mr. Wallace repudiate. 
wanted; and as these variations were never withheld, it would prove that the sanction of an all-wise and all powerful Being has been given to that which the highest human minds consider to be trivial, mean, or debasing." (p. 290 ${ }^{1}$

The Nebular Hypothesis, as propounded by La Place, proposed to account for the origin of the universe, by a process of evolution under the control of mere physical forces. That hypothesis has, so far as evolution is concerned, been adopted by men who sincerely believe in God and in the Bible. But they hold not only that God created matter and endowed it with its properties, but that He designed the universe, and so controlled the operation of physical laws that they accomplished his purpose. So there are Christian men who believe in the evolution of one kind of plants and animals out of earlier and simpler forms; but they believe that everything was designed by God, and that it is due to his purpose and power that all the forms of vegetable and animal life are what they are. But this is not the question. What Darwin and the ad-

1 That God permits men in the use of the laws of nature to distil alcohol and brew poisons, does not prove that He approves of drunkenness or murder. 
vocates of his theory deny, is all design. The organs, even the most complicated and wonderful, were not intended. They are said to be due to the undirected and unintended operation of physical laws. This is Mr. Wallace's argument. He endeavors to show that it is unworthy of God that He should be supposed to have contrived the mechanism of the orchids, as a mechanis' contrives a curious puzzle.

We recently heard Prof. Joseph Henry, in a brief address, say substantially: "If I take brass, glass, and other materials, and fuse them, the product is a slag. This is what physical laws do. If I take those same materiais, and form them into a telescope, that is what mind does." This is the whole question in a nutshell. That design implies an intelligent designer, is a self evident truth. Every man believes it; and no man can practically disbelieve it. Even those naturalists who theoretically deny it, if they find in a cave so simple a thing as a flint arrow-head, are as sure that it was made by a man as they are of their own existence. And yet they want us to believe that an eagle's eye is the product of blind natural causes. No combination of physical forces ever made a ship or a locomotive. 
It may, indeed, be said that they are dead matter, whereas plants and animals live. But what is life but one form of the organizing efficiency of God?

Mr. Wallace does not go as far as Mr. Darwin. He recoils from regarding man either as to body or soul as the product of mere natural canses. He insists that "a superior intelligence is necessary to account for man." ( $p$. 359) This of course implies that the agency of no such higher intelligence is admitted in the production of plants or of aninals lower than man.

\section{Professor Huxley.}

The second witness as to the character of Mr. Darwin's theory is Professor Huxley. We have some hesitation in including the name of this distinguished naturalist among the advocates of Darwinism. ${ }^{1}$ On the one hand, in his

1 Mr. Huxley, if we may judge from what he says of himself, is somewhat liable to be misunderstood. He says he was fourteen years laboring to resist the charge of Positivism made against the class of scientifie men to which he belongs. He also tells us in his letter to Professor Tyndall, prefixed to his volume of Lay Sermons and Addresses, that the "Essay on the Physical Basis of Life," included in that volume, was intended as a protest, from the philosophical side, against what is commonly called Materialism. It turned out, however, that the public re- 


\section{Essay on the Origin of Species, printed in the "Westminster Review," in 1860, and re-}

garded it as an argument in favor of Materialism. This we think was a very natural, if not an unavoidable mistake, on the part of the public. For in that Essay, he says that Protoplasm, or the physical basis of life, " is a kind of matter common to all living beings, that the powers or faculties of all kinds of living matter, diverse as they may be in degree, are substantially of the same kind." Protoplasm as far as examined contains the four elements, - carbon, hydrogen, oxygen, and nitrogen. These are lifeless bodies, "but when brought together under certain conditions, they give rise to the still more complex body Protoplasm; and this protoplasm exhibits the phenomena of life." There is no more reason, he teaches, for assuming the existence of a mysterious something called vitality to account for vital phenomena, than there is for the assumption of something called Aquasity to account for the phenomena of water. Life is said to be "the product of a certain disposition of material molecules." The matter of life is " composed of ordinary matter, differing from it only in the manner in which its atoms are aggregated. I take it," he says, "to be demonstrable that it is utterly impossible to prove that anything whatever may not be the effect of a material and necessary cause, and that human logic is equally incompetent to prove that any act is really spontaneous. A really spontaneous act is one, which, by the assumption, has no cause ; and the attempt to prove such a negative as this, is on the face of the matter absurd. And while it is thus a philosophical impossibility to demonstrate that any given phenomenon is not the effect of a material cause, any one who is acquainted with the history of science will admit that its progress has, in all ages, meant, and now more than ever means, the extension of what we call matter and causation, and the concomitant gradual banishment from all regions of human thought of what we call spirit and spontaneity." 
printed in his "Lay Sermons," etc., in 1870, he says: "There is no fault to be found with Mr. Darwin's method, but it is another thing whether he has fulfilled all the conditions imposed by that method. Is it satisfactorily proved that species may ${ }^{1}$ be originated by selection? that none of the phenomena exhibited by species are inconsistent with the origin of species in this way? If these questions can be answered in the affirmative, Mr. Darwin's view steps out of the rank of hypotheses into that of theories; but so long as the evidence at present adduced falls short of enforcing that affirmative, so long, to our minds, the new doctrine must be content to remain among the former, - an extremely valuable, and in the highest degree probable, doctrine; indeed, the only extant hypothesis which is worth anything in a scientific point of view; but still a hypothesis, and not yet a theory of species. After much consideration," he adds,

1 It eannot escape the attention of any one that Mr. Darwin, Mr. Wallace, Professor Huxley, and all the other advocates or defenders of Darwinism, do not pretend to prove anything more than that species may be originated by selection, not that there is no other satisfactory account of their origin. Mr. Darwin admits that referring them to the intention and efficiency of God, accounts for everything, but, he says, that is not science. 
" and assuredly with no bias against Mr. Darwin's views, it is our clear conviction that, as the evidence now stands, it is not absolutely proven that a group of animals, having all the characters exhibited by species in Nature, has ever been originated by selection, whether artificial or natural." 1

Again, in his work on "Man's Place in Nature," he expresses himself much to the same effect: "A true physical cause is admitted to be such only on one condition, that it shall account for all the phenomena which come within the range of its operation. If it is inconsistent with any one phenomenon it must be rejected; if it fails to explain any one phenomenon it is so far to be suspected, though it may have a perfect right to provisional acceptance. ... Our acceptance, therefore, of the Darwinian hypothesis must be provisional so long as one link in the chain of evidence is wanting; and so long as all the animals and plants certainly produced by selective breeding from a common stock are fertile, and their progeny are fertile one with another, that link will be wanting. For so long selective

1 Lay Sermons, Addresses, and Reviews. By Thomas Henry Huxley, LL. D., F. R. S. London, 1870, p. 323. 
breeding will not be proved to be competent to all that is required if it produce natural species." I In immediate connection with the above passage, there is another which throws a clear light on Professor Huxley's cosmical views. "The whole analogy of natural operations furnish so complete and crushing an argument against the intervention of any but what are called secondary causes, in the production of all the phenomena of the universe; that, in view of the intimate relations of man and the rest of the living world, and between the forces exerted by the latter and all other forces, I can see no reason for doubting that all are coördinate terms of nature's great progression, from formless to formed, from the inorganic to the organic, from blind force to conscious intellect and will." 2

1 Evidence of Man's Place in Nature. London, 1864, p. 107.

2 Since writing the above paragraph our eye fell on the following note on the 89th page of the Duke of Argyle's Reign of Law, which it gives us pleasure to quote. It seems that a writer in the Spectator had charged Professor Huxley with Atheism. In the number of that paper for February 10,1866, the Professor replies: "I do not know that I care very much about popular odium, so there is no great merit. in saying that if. I really saw fit to deny the existence of a God I should certainly do so, for the sake of my own intellectual freedom, and be the honest atheist you are pleased to say I am. As it happens, however, I cannot take this 
Ought not this to settle the matter? Are we to give up the Bible and all our hopes for the sake of an hypothesis that all living things, including man, on the face of the earth, are descended from a primordial animalcule, by natural selection, when such a man as Huxley, who (as Voltaire said of the prophet Habbakuk) is capable de tout, says that it has not been proved that any one species has thus originated?

But on the other hand, while he honestly admits that Darwin's doctrine is a mere hypothesis and not a theory, he has nevertheless written at least three essays or reviews in its exposition and vindication. $\mathrm{He}$ is freely referred to on the continent of Europe, at least, as an ardent advocate of the doctrine; and he quotes without protest such designations of himself. At any rate, as he assures his readers that he has no bias against Mr. Darwin's views, as he has devoted much time and attention to the subject, and as he is one of the most promposition with honesty, inasmueh as it is, and always has been, a favorite tenet, that Atheism is as absurd, logieally speaking, as Polytheism." In the same paper he says, "The denying the possibility of miracles seems to me quite as unjustifiable as speeulative Atheism." How this can be reeoneiled with the passages quoted above, we are unable to see. 
inent naturalists of the age, there can be no question as to his competency as a witness as to what Darwinism is.

His testimony that Mr. Darwin's doctrine excludes all teleology, or final causes, is explicit. In his review of the "Criticisms on the Origin of Species," he says, "that when he first read Mr. Darwin's book, that which struck him most forcibly was the conviction that teleology, as commonly understood, had received its death-blow at Mr. Darwin's hands. For the teleological argument runs thus: An organ is precisely fitted to perform a function or purpose ; therefore, it was specially constructed to perform that function. In Paley's famous illustration, the adaptation of all the parts of a watch to the function or purpose of showing the time, is held to be evidence that the watch was specially contrived to that end; on the ground that the only cause we know of competent to produce such an effect as a watch which shall keep time, is a contriving intelligence adapting the means directly to that end." " This, Mr. Huxley tells us, is precisely what Darwin denies with reference to the organs of plants and animals. The eye

1 Lay Sermons, etc., p. 330. 
was not formed for the purpose of seeing, or the ear for hearing. It so happened that a nerve became sensitive to light; then in course of time, it happened that a transparent tissue came over it; and thus in "millions of years" an eye, as we have seen above, happened to be formed. No such organ was ever intended or designed by God or man. "An apparatus," says Professor Huxley, "thoroughly adapted to a particular purpose, might be the result of a method of trial and error worked by unintelligent agents, as well as by the application of means appropriate to the end by an intelligent agent." "For the notion that every organism has been created as it is and launched straight at a purpose, Mr. Darwin substitutes the conception of something, which may fairly be termed a method of trial and error. Organisms vary incessantly; of these variations the few meet with surrounding conditions which suit them, and thrive; the many are unsuited, and become extinguished." "For the teleologist an organism exists, because it was made for the conditions in which it is found ; for the Darwinian an organism exists, because, out of many of its kind, it is the only one which has been able to persist in the conditions in which 
it is found." "If we apprehend," Huxley further says, "the spirit of the "Origin of Species" rightly, then, nothing can be more entirely and absolutely opposed to teleology, as it is commonly understood, than the Darwinian theory." (p. 303)

It has already been stated that Mr. Wallace does not apply the doctrine of evolution to man; neither does Mr. Mivart, a distinguished naturalist, who is a member of the Latin Church. The manner. in which Professor Huxley speaks of these gentlemen shows how thoroughly, in his judgment, Mr. Darwin banishes God from his works: "Mr. Wallace and Mr. Mivart are as stout evolutionists as Mr. Darwin himself; but Mr. Wallace denies that man can have been evolved from a lower animal by that process of natural selection, which he, with Mr. Darwin, holds to be sufficient for the evolution of all animals below man; while Mr. Mivart, admitting that natural selection has been one of the conditions of the animals below man, maintains that natural selection must, even in their case, have been supplemented by some other cause, - of the nature of which, unfortunately, he does not give us any idea. Thus Mr. Mivart is less of a Dar- 
winian than Mr. Wallace, for he has faith in the power of natural selection. But he is more of an evolutionist than $\mathrm{Mr}$. Wallace, because Mr. Wallace thinks it necessary to call in an intelligent agent, a sort of supernatural Sir John Sebright, to produce even the animal frame of man; while Mr. Mivart requires no Divine assistance till he comes to man's soul." 1

1 Contemporary Review, vol. xviii. 1871, p. 444. In this same article Mr. Huxley says: "Elijah's great question, Will ye serve God or Baal? Choose ye, is uttered audibly enough in the ears of every one of us as we come to manhood. Let every man who tries to answer it seriously ask himself whether he ean be satisfied with the Baal of authority, and with all the good things his worshippers are promised in this world and the next. If he can, let hin, if he be so inclined, amuse himself with such seientifie implements as authority tells him are safe and will not cut his fingers; but let him not imagine that he is, or ean be, both a true son of the Chureh and a loyal soldier of seience." "And, on the other hand, if the blind acceptance of authority appear to him in its true colors, as mere private judgment in excelsis, and if he have courage to stand alone face to face with the abyss of the Eternal and Unknowable, let him be content, once for all, not only to renounce the good things promised by 'Infallibility,' but even to bear the bad things which it prophesies; eontent to follow reason and faet in singleness and honesty of purpose, wherever they may lead, in the sure faith that a hell of honest men will to him be more endurable than a paradise full of angelic shams." There ean be no doubt that the Apostle Paul believed in the infallibility of the Scriptures. Inagine Professor Huxley calling St. Paul to his face, a sham! What are all the Huxleys who have ever lived or ever can live, to that one Paul in power for good over human thought, character, and destiny! 
In the "Academy" for October, 1869, there is a review by Professor Huxley of Dr. Haeckel's "Naturliśche Schöpfungsgeschichte," in which he says: "Professor Haeckel enlarges on the service which the 'Origin of Species' has done in favoring what he terms 'the causal or mechanical' view of living nature as opposed to the 'teleological or vitalistic' view. And no doubt it is quite true the doctrine of evolution is the most formidable of all the commoner and coarser forms of teleology. Perhaps the most remarkable service to the philosophy of Biology rendered by Mr. Darwin is the reconciliation of Teleology and Morphology, and the explanation of the facts of both which his view offers.

"The teleology which supposes that the eye,

Professor Huxley goes on in the next paragraph to say: "Mr. Mivart asserts that " without belief in a personal God there is no religion worthy of the name.' This is a matter of opinion. But it may be asserted, with less reason to fear contradiction, that the worship of a personal God, who, on Mr. Mivart's hypothesis, must have used words studiously calculated to deceive his creatures and worshippers, is 'no religion worthy of the name.' 'Incredibile est, Deum illis verbis ad populum fuisse locutum quibis deciperetur,' is a verdict in which for once Jesuit casuistry concurs with the healthy moral sense of all mankind." (p. 458). Mr. Huxley calls believers in the Scriptures, and (apparently) believers in a persoual God, bigots, old ladies of both sexes, bibliolators, fools, etc., etc. 
such as we see it in man or in the higher vertebrata, was made with the precise structure which it exhibits, to make the animal which possesses it to see, has undoubtedly received its death-blow. But it is necessary to remember that there is a higher teleology, which is not touched by the doctrine of evolution, but is actually based on the fundamental proposition of evolution. That proposition is, that the whole world, living and not living, is the result of the mutual interaction, according to definite laws, of forces possessed by the molecules of which the primitive nebulosity of the universe was composed. If this be true, it is no less certain that the existing world lay potentially in the cosmic vapor; and that a sufficient intelligence could, from a knowledge of the properties of that vapor, have predicted, say, the state of fauna of Great Britain in 1869, with as much certainty as one can say what will happen to the vapor of the breath on a cold winter's day." This is the doctrine of the self-evolution of the universe. We know not what may lie behind this in Mr. Huxley's mind; but we are very sure that there is not an idea in the above paragraph which Epicurus of old, and Büchner, Voght, Haeckel, and other "Material- 
isten von Profession," would not cheerfully adopt. His distinction between a higher and lower teleology is of no account in this discussion. What is the teleology to which, he says, $\mathrm{Mr}$. Darwin has given the death-blow, the extracts given above clearly show. The eye, Huxley says, was not made for the purpose of seeing, or the ear for the purpose of hearing. "According to teleology," he says, " each organism is like a rifle bullet fired straight at a mark; according to Darwin, organisms are like grapeshot, of which one hits something and the rest fall wide." 1

\section{Büchner.}

Dr. Louis Büchner, president of the medical association of Hessen-Darmstadt, etc., etc., is not only a man of science but a popular writer. Perhaps no book of its class, in our day, has been so widely circulated as his volume on "Kraft und Stoff," Matter and Force. It has been translated into all the languages of Europe. He holds that matter and force are inseparable; there cannot be the one without the other; both are eternal and imperishable; neither can be either increased or diminished;

1 Lay Sermons, etc. p. 331. 
life originated spontaneously by the combination of molecules of matter under favorable conditions; all the phenomena of the universe, inorganic and organic, whether physical, vital, or mental, are due to matter and its forces. Consequently there is no God, no creation, no mind distinct from matter, no conscious existence of man after death. All this is asserted in the most explicit terms. Dr. Büchner has published a work on Darwinism in two volumes. Darwin's theory, he says, "is the most thoroughly naturalistic that can be imagined, and far more atheistic than that of his decried predecessor Lamarck, who admitted at least a general law of progress and development; whereas, according to Darwin, the whole development is due to the gradual summation of innumerable minute and accidental operations." 1

\section{Carl Vogt.}

In his preface to his work on the "Descent of Man," Mr. Darwin quotes this author as a high authority. We see him elsewhere referred to as one of the first physiologists of Germany. Vogt devotes the concluding lecture of

1 Sechs Vorlesungen über die Darwinische Theorie. Von Ludwig Büchner. Zweite Auflage, Leipzig, 1848, vol. i. p. 125. 
the second volume of his work on Man, to the consideration of Darwinism. He expresses his opinion of it, after high commendation, in the following terms. He says that it cannot be doubted that Darwin's " theory turns the Creator - and his occasional intervention in the revolutions of the earth and in the production of species - without any hesitation out of doors, inasmuch as it does not leave the smallest room for the agency of such a Being. 'The first living germ being granted, out of it the creation develops itself progressively by natural selection, through all the geological periods of our planets, by the simple law of descent no new species arises by creation and none perishes by divine annihilation - the natural course of things, the process of evolution of all organisms and of the earth itself, is of itself sufficient for the production of all we see. Thus Man is not a special creation, produced in a different way, and distinct from other animals, endowed with an individual soul and animated by the breath of God; on the contrary, Man is only the highest product of the progressive evolution of animal life springing from the group of apes next below him." 1

1 Vorlesungen über den Menschen, seine Stellung in der Schoep. 
After this no one can be surprised to hear him say, that "the pulpits of the orthodox, the confessionals of the priests, the platforms of the interior missions, the presidential chairs of the consistories, resound with protestations against the assaults made by Materialism and Darwinism against the very foundations of society." (p. 286) This he calls "Das Wehgeschrei der Moralisten" (the Wail of the Moralists). The designation Moralists is a felicitous one, as applied to the opponents of Vogt and his associates. It distinguishes them as men who have not lost their moral sense; who refuse to limit their faith to what can be proved by the five senses; who bow to the authority of the law written by the finger of God, on the hearts of men, which neither sophistry nor wickedness can effectually erase. All Vogt thinks it necessary to reply to these Moralists is, "Lasst sie bellen, bis sie ausgebellt haben" (Let them bark till they are tired). "Ende."

\section{Haeckel.}

Dr. Ernst Haeckel, Professor in the University of Jena, is said to stand at the head of fung und in der Geschichte der Erde. Von Carl Vogt. Giessen, 1863, vol. ii. p. 260 . 
the living naturalists of Germany. His work on "Natural History of Creation" contains a course of lectures delivered to the professors, students, and citizens of Jena. It is, therefore, somewhat popular in its character. The ability of the writer is manifest on every page. The distinctness of his perceptions, precision of language, perspicuity of style, and the strength of his convictions, give the impression of a man fully master of his subject, who has thought himself through, and is perfectly satisfied with the conclusions at which he has arrived. At the same time it is the impression of a man who is developed only on one side; who never looks within; who takes no cognizance of the wonders revealed in consciousness; to whom the intuitions of reason and of the conscience, the sense of dependence on a will higher than our own - the sense of obligation and responsibility are of no account, in short a man to whom the image of God enstamped on the soul of man is invisible. This being the case, he that is least in the kingdom of heaven is greater than he.

Haeckel admits that the title of his book, "Natural Creation," $i$. e. creation by natural laws, is a contradiction. He distinguishes, 
however, between the creation of substance and the creation of form. Of the former he says science knows nothing. To the scientist matter is eternal. If any one chooses to assume that it was created by an extramundane power, Haeckel says he will not object. But that is a matter of faith; and "where faith begins, science ends." The very reverse of this is true. Science must begin with faith. It cannot take a single step without it. How does Haeckel know that his senses do not deceive him? How does he know that he can trust to the operations of his intellect? How does he know that things are as they appear? How does he know that the universe is not a great phantasmagoria, as so many men have regarded it, and man the mere sport of chimeras? He must believe in the laws of belief impressed on his nature. Knowledge implies a mind that knows, and confidence in the act of knowing implies belief in the laws of mind. "An inductive science of nature," says President Porter, "presupposes a science of induction, and a science of induction presupposes a science of man."1 Haeckel, however, says faith

1 The Science of Nature versus the Science of Man. By Noah Porter, President of Yale College. New York, 1871, p. 29. 
is the mere product of the poetic imagination; science, of the understanding; if its conclusions come into conflict with the creations of the imagination, the latter, of course, must give way. ${ }^{1}$

He says, there have ever been two conflicting theories of the universe : the one, monistic ; the other, dualistic. The one admits of only one substance, matter ; the other of two, matter and mind. He prefers to call the former monism rather than materialism, because the latter term often includes the idea of moral materialism, $i$. e. the doctrine that sensual pleasure is the end of life; a doctrine, he says, much more frequently held by princely churchmen than by men of science. He maintains, however, that "all knowable nature is one; that the same eternal, immutable (ehernen, brazen) laws are active in the life of animals and plants, in the formation of crystals, and the power of steam; in the whole sphere of biology, zoölogy, and botany. We have, therefore, the right to hold fast the monistic and mechanical view, whether men choose to

I Natürliche Schöpfungsgeschichte. Von Dr. Ernst Haeckel, Professor in der Universität Jena. Zweite Auflage, Berlin, 1873, pp. 8, and 9. 
brand the system as Materialism or not. In this sense, all natural science, with the law of causation at its head, is thoroughly materialistic." (p. 32)

The monistic theory he calls "mechanical or causal," as distinguished. from the dualistic theory, which he calls "teleological or vitalistic." According to the latter, "the vegetable and animal kingdoms are considered as the products of a creative agency, working with a definite design. In looking on an organism, the conviction seems unavoidable that so skilfully constructed a machine, such a complicated working apparatus, as an organism is, could be produced only by an agency analogous to, although far more perfect than the agency of man." "This," he says, "supposes the Creator to be an organism analogous to man, although infinitely more perfect; who contemplates his formative powers, lays the plan of the machine, and then, by the use of appropriate means, produces an effect answering to the preconceived plan..... However highly the Creator may be exalted, this view involves the ascription to Him of human attributes, in virtue of which he can form a plan, and construct organisms to correspond with it. That 
is the view to which Darwin's doctrine is directly opposed, and of which Agassiz is, among naturalists, the most important advocate. The famous work of Agassiz, 'Essay on Classification,' which is in direct opposition to Darwin's, and appeared about the same time, has carried out logically to the utmost the absurd anthropomorphic doctrine of a Creator." (p. 17)

The monistic theory is called "mechanical and causal," because it supposes that all the phenomena of the universe, organic and inorganic, vegetable and animal, vital and mental, are due to mechanical or necessarily operating causes (causæ efficientes); just as the dualistic theory is called "teleological or vitalistic," because it refers natural organisms to causes working for the accomplishment of a given end (causæ finales). (p. 67)

The grand difficulty in the way of the mechanical or monistic theory was the occurrence of innumerable organisms, apparently at least, indicative of design. To get over this difficulty, Haeckel says, some who could not believe in a creative and controlling mind adopted the idea of a metaphysical ghost called vitality. The grand service rendered by Darwin to science is, that his theory enables us to 
account for the appearances of design in nature without assuming final causes, or, a mind working for a foreseen and intended end. "All that had appeared before Darwin," he says, "failed to secure success, and to meet with general acceptance of the doctrine of the mechanical production of vegetable and animal organisms. 'This was accomplished by Darwin's theory." (p. 20)

The precise difficulty which Mr. Darwin s doctrine has, according to Haeckel, enabled men of science to surmount, is thus clearly stated on p. 633. It is, "that organs for a definite end should be produced by undesigning or mechanical causes." This difficulty is overcome by the doctrine of evolution. "Through the theory of descent, we are for the first time able to establish the monistic doctrine of the unity of nature, that a mechaniccausal explanation of the most complicated organisms, e. $g$. the formation and constitution of the organs of sense, have no more difficulty for the common understanding, than the mechanical explanation of any physical process, as, for example, earthquakes, the direction of the winds, or the currents of the sea. IVe thus arrive at the conviction of the last im- 
portance, that all natural bodies with which we are acquainted are equally endowed with life (gleichmässig belebt sind); that the distinction between living and dead matter does not exist. When a stone is thrown into the air and falls by certain laws to the ground, or when a solution of salt forms a crystal, the result is neither more nor less a mechanical manifestation of life, than the flowering of a plant, the generation or sensibility of animals, or the feelings or the mental activity of man. In thus establishing the monistic theory of nature lies the highest and most comprehensive merit of the doctrine of descent, as reformed by Darwin." (p. 21) "As to the much vaunted design in nature, it is a reality only for those whose views of animal and vegetable life are to the last degree superficial. Any one who has gone deeper into the organization and vital activity of animals and plants, who has made himself familiar with the action and reaction of vital phenomena, and the so-called economy of nature, comes of necessity to the conclusion, that design does not exist, any more than the vaunted goodness of the Creator" (die vielgerïhmte Allgüte des Schöpfers). (p. 17) 
Professor Huxley, in his review of this work of Haeckel, already quoted, says: "I do not like to conclude without reminding the reader of my entire concurrence with the general tenor and spirit of the work, and of my high estimate of its value." If you take out of Haeckel's book its doctrine of Monism, which he himself says means Materialism, it has no "tenor or spirit" in it. It is not, however, for us to say how far Professor Huxley intended his.indorsement to go.

Haeckel says that Darwin's theory of evolution leads inevitably to Atheism and Materialism. In this we think he is correct. But we have nothing to do with Haeckel's logic or with our own. We make no charge against Mr. Darwin. We cite Haeckel merely as a witness to the fact that Darwinism involves the denial of final causes ; that it excludes all intelligent design in the production of the organs of plants and animals, and even in the production of the soul and body of man. This first of German naturalists would occupy a strange position in the sight of all Europe, if, after lauding a book to the skies because it teaches a certain doctrine, it should turn out that the book taught no such doctrine at all. 


\section{The Opponents of Darwinism. The Duke of Argyll.}

When cultivated men undertake to refute a certain system, it is to be presumed that they give themselves the trouble to ascertain what that system is. As the advocates of $\mathrm{Mr}$. Darwin's theory defend and applaud it because it excludes design, and as its opponents make that the main ground of their objection to it, there can be no reasonable doubt as to its real character. The question is, How are the contrivances in nature to be accounted for? One answer is, They are due to the purpose of God. Mr. Darwin says, They are due to the gradual and undesigned accumulation of slight variations. The Duke's first objection to that doctrine is, that the evidence of design in the organs of plants and animals is so clear that $\mathrm{Mr}$. Darwin himself cannot avoid using teleological language. "He exhausts," he says, "every form of words and of illustration by which intention or mental purpose can be described. ' Contrivance,' ' beautiful contrivance,' 'curious contrivance,' are expressions which occur over and over again. Here is one sentence describing a particular species (of orchids): "The 
labellum is developed in order to attract the Lepidoptera; and we shall soon see reason for supposing that the nectar is purposely so lodged, that it can be sucked only slowly in order to give time for the curious chemical quality of the matter setting hard and dry." "1 We have already seen that Mr. Darwin's answer to this objection is, that it is hard to keep from personifying nature, and that these expressions as used by him mean no more than chemists mean when they speak of affinities, and one element preferring another.

A second objection is, that a variation would not be useful to the individual in which it happens to occur, unless other variations should occur at the right time and in the right order; and that the concurrence of so many accidents as are required to account for the infinite diversity of forms in plants and animals, is altogether inconceivable.

A third objection is, that the variations often have no reference to the organism of the animal itself but to other organisms. "Take one instance," he says, "out of millions. The poison of a deadly snake, - let us for a moment consider what that is. It is a secretion

1 Reign of Lnw. I.ondon, 1867, p. 40. 
of definite chemical properties with reference not only - not even mainly - to the organism of the animal in which it is developed, but specially to another animal which it is intended to destroy." "How," he asks, "will the law of growth adjust a poison in one animal with such subtle knowledge of the organization of the other, that the deadly virus shall in a few minutes curdle the blood, benumb the nerves, and rush in upon the citadel of life? There is but one explanation: a Mind having minute and perfect knowledge of the structure of both has designed the one to be capable of inflicting death upon the other. This mental purpose and resolve is the one thing which our intelligence perceives with direct and intuitive recognition. The method of creation by which this purpose has been carried into effect is utterly unknown." 1

A fourth objection has reference to beauty. According to Mr. Darwin, flowers are not intentionally made beautiful, but those which happen to be beautiful attract insects, and by their agency are fertilized and survive. Male birds are not intentionally arrayed in bright colors, but those which happen to be so ar-

1 Reign of Law. London, 1867, p. 37. 
rayed are attractive, and thus become the progenitors of their race. Against this explanation the Duke earnestly protests. He refers to the gorgeous adorned class of Hummingbirds, of which naturalists enumerate no less than four hundred and thirty different species, distinguished one from the other, in general, only by their plumage. "Now," he asks, "what explanation does the law of natural selection give, - I will not say of the origin, but even of the continuance of such specific varieties as these? None whatever. A crest of topaz is no better in the struggle of existence than a crest of sapphire. A frill ending in spangles of the emerald is no better in the battle of life than a frill ending in spangles of the ruby. A tail is not affected for the purposes of flight, whether its marginal, or its central feathers are decorated with white. It is impossible to bring such varieties into any physical law known to us. It has relation however to a Purpose, which stands in close analogy with our knowledge of purpose in the works of men. Mere beauty and mere variety, for their own sake, are objects which we ourselves seek, when we can make the forces of nature subordinate to the attain- 
ment of them. There seems to be no conceivable reason why we should doubt or question that these are ends and aims also in the forms given to living organisms, when the facts correspond with this view and with no other." 1

It will be observed that all these objections have reference to the denial of teleology on the part of $\mathrm{Mr}$. Darwin. If his theory admitted that the organisms in nature were due to a divine purpose, the objections would be void of all meaning.

There is a fifth objection. According to Darwin's theory organs are formed by the slow accumulation of unintended variations, which happen to be favorable to the subject of them in the struggle for life. But in many cases these organs, instead of being favorable, are injurious or cumbersome until fully developed. Take the wing of a bird, for example. In its rudimental state, it is useful neither for swimming, walking, nor flying. Now, as Darwin says it took millions of years to bring the eye to perfection, how long did it take to render a rudimental wing useful? It is no sufficient answer to say that these rudimental organs might have been suited to the condition

I Reign of Law, pp. 247, 248. 
in which the animal existed, during the formative process. This is perfectly arbitrary. It has no basis of fact. There are but three kinds of locomotion that we know of: in the water, on the ground, and through the air; for all these purposes a half-formed wing would be an impediment.

The Duke devotes almost a whole chapter of his interesting book to the consideration of " contrivance in the machinery for flight." The conditions to secure regulated movement through the atmosphere are so numerous, so complicated, and so conflicting, that the problem never has been solved by human ingenuity. In the structure of the bird it is solved to perfection. As we are not writing a teleological argument, but only producing evidence that Darwinism excludes teleology, we cannot follow the details which prove that the wing of the gannet or swift is almost as wonderful and beautiful a specimen of contrivance as the eye of the eagle.

\section{Agassiz.}

Every one knows that the illustrious Agassiz, over whose recent grave the world stands weeping, was from the beginning a pronounced 
and earnest opponent of Mr. Darwin's theory. He wrote as a naturalist, and therefore his objections are principally directed against the theory of evolution, which he regarded as not only destitute of any scientific basis, but as subversive of the best established facts in zoölogy. Nevertheless it is evident that his zeal was greatly intensified by his apprehension that a theory which obliterates all evidence of the being of God from the works of nature, endangered faith in that great doctrine itself. The Rev. Dr. Peabody, in the discourse delivered on the occasion of Professor Agassiz's funeral, said: "I cannot close this hasty and inadequate, yet fervent and hearty tribute, without recalling to your memory the reverent spirit in which he pursued his scientific labors. Nearly forty years ago, in his first great work on fossil fishes, in developing principles of classification, he wrote in quotations, 'An invisible thread in all ages runs through this immense diversity, exhibiting as a general result that there is a continual progress in development ending in man, the four classes of vertebrates presenting the intermediate steps, and the invertebrates the constant accessory accompaniment. Have we not here the mani- 
festation of a mind as powerful as prolific? an act of intelligence as sublime as provident? the marks of goodness as infinite as wise? the most palpable demonstration of the existence of a personal God, author of all this; ruler of the universe, and the dispenser of all good ? This at least is what I read in the works of creation.' And it was what he ever read, and with profound awe and adoration. To this exalted faith he was inflexibly loyal. The laws of nature were to him the eternal Word of God.

"His repugnance to Darwinism grew in great part from his apprehension of its atheistical tendency, - an apprehension which I confess I cannot share; for I forget not that these theories, now in the ascendent, are maintained by not a few devout Christian men, and while they appear to me unproved and incapable of demonstration, I could adinit them without parting with one iota of my faith in God and Christ. Yet I cannot but sympathize most strongly with him in the spirit in which he resisted what seemed to him.lese-majesty against the sovereign of the universe. Nor was his a theoretical faith. His whole life, in its broad philanthropy, in its pervading spirit 
of service, in its fidelity to arduous trusts and duties, and in its simplicity and truthfulness, bespoke one who was consciously fulfilling a mission from God to his fellow-men."

The words "evolution" and "Darwinism" are so often in this country, but not in Europe, used interchangeably, that it is conceivable that Dr. Peabody could retain his faith in God, and yet admit the doctrine of evolution. But it is not conceivable that any man should adopt the main element of Mr. Darwin's theory, viz., the denial of all final causes, and the assertion, that since the first creation of matter and life, God has left the universe to the control of unintelligent physical causes, so that all the phenomena of the plants and animals, all that is in man, and all that has ever happened on the earth, is due to physical force, and yet retain his faith in Christ. On that theory, there have been no supernatural revelation, no miracles; Christ is not risen, and we are yet in our sins. It is not thus that this matter is regarded abroad. The Christians of Germany say that the only alternative these theories leave us, is Heathenism or Christianity; "Heidenthum oder Christenthum, Die Frage der Zeit." 


\section{Janet.}

Janet, a professor of philosophy, is the author of a book on the Materialism of Büchner. ${ }^{1}$ The greater part of the last chapter of his work is devoted to Darwinism. He says, "Dr. Büchner invoked (Darwin's book) as a striking confirmation of his doctrine." (p. 154) What Büchner's doctrine is has been shown on a previous page. The points of coincidence between Darwin's system and his are, that both regard mind as a mere function of living matter; and both refer all the organs and organisms of living things to the unconscious, unintelligent operation of physical causes. Büchner's way of accounting for complicated organs was, " that the energy of the elements and forces of matter, which in their fated and accidental occurrence must have produced innumerable forms, which must needs limit each other mutually, and correspond, apparently, the one with the other, as if they were made for that purpose. Out of all those forms, they

1 The Materialism of the Present Day: a Critique of Dr. Büchner's System. By Paul Janet, Member of the Institute of France, Professor of Philosophy at the Paris Faeulte des Lettres. Translated from the French, by Gustave Masson, B. A London and Paris, 1867. 
only have survived which were adapted, in some manner, to the conditions of the medium in which they were placed." (p. 30) This is very clumsy. No wonder Biichner preferred Darwin's method. The two systems are, indeed, exactly the same, but Mr. Darwin has a much more winning way of presenting it.

Professor Janet does not seem to have much objection to the doctrine of evolution in itself; it is the denial of teleology that he regards as the fatal element of Mr. Darwin's theory. "According to us," he says, "the true stumblingblock of Mr. Darwin's theory, the perilous and slippery point, is the passage from artificial to natural selection; it is when he wants to establish that a blind and designless nature has been able to obtain, by the occurrence of circumstances, the same results which man obtains by thoughtful and well calculated industry." (p. 174)

Towards the end of his volume he says: "We shall conclude by a general observation. Notwithstanding the numerous objections we have raised against Mr. Darwin's theory, we do not declare ourselves hostile to a system of which zoölogists are the only competent judges. We are neither for nor against the transmu- 
tation of species, neither for nor against the principle of natural selection. The only positive conclusion of our debate is this: no principle hitherto known, neither the action of media, nor habit, nor natural selection, can account for organic adaptations without the intervention of the principle of finality. Natural selection, unguided, submitted to the laws of a pure mechanism, and exclusively determined by accidents, seems to me, under another name, the chance proclaimed by Epicurus, equally barren, equally incomprehensible; on the other hand, natural selection guided beforehand by a provident will, directed towards a precise end by intentional laws, might be the means which nature has selected to pass from one stage of being to another, from one form to another, to bring to perfection life throughout the universe, and to rise by a continuous process from the monad to man. Now, I ask Mr. Darwin himself, what interest has he in maintaining that natural selection is not guided - not directed ? What interest has he in substituting accidental causes for every final cause? I cannot see. Let him admit that in natural, as well as in artificial selection, there may be a choice and direction; his principle immediately becomes 
much more fruitful than it was before. His hypothesis, then, whilst having the advantage of exempting science from the necessity of introducing the personal and miraculous intervention of God in the creation of each species, yet would be free from the banishing out of the universe an all-provident thought, and of submitting everything to blind and brute chance." (pp. 198, 199) Professor Janet asks far too much of Mr. Darwin. To ask him to give up his denial of final causes is like asking the Romanists to give up the Pope. That principle is the life and soul of his system.

\section{Flourens.}

M. Flourens, recently dead, was one of the earliest and most pronounced opponents of Darwinism. He published in 1864 his "Examen du Livre de M. Darwin sur l'Origine des Espèces." His position as Member of the Académie Française, and Perpetual Secretary of the Académie des Sciences, or Institut de France, vouch for his high rank among the French naturalists. His connection with the Jardin des Plantes ga ve him enlarged opportunities for biological experiments. The result of his own experience, as well as the expe- 
rience of other observers, was, as he expresses it, his solemn conviction that species are fixed and not transmutable. No ingenuity of device could render hybrids fertile. "They never establish an intermediate species." It is, therefore, to the doctrine of evolution his attention is principally directed. Nevertheless, he is no less struck by Darwin's way of excluding all intelligence and design in his manner of speaking of nature. On this point he quotes the language of Cuvier, who says: "Nature has been personified. Living beings have been called the works of nature. The general bearing of these creatures to each other has become the laws of nature. It is thus while considering Nature as a being endowed with intelligence and will, but in its power limited and secondary, that it may be said that she watches incessantly over the maintenance of her work; that she does nothing in vain, and always acts by the most siniple means. . . . . It is easy to see how puerile are those who give nature a species of individual existence distinct from the Creator, and from the law which $\mathrm{He}$ has impressed upon the movements and peculiarities of the forms given by Him to living things, and which $\mathrm{He}$ makes to act upon their 
bodies with a peculiar force and reason." Older writers, says Flourens, in speaking of Nature, "gave to her inclinations, intentions, and views, and horrors (of a vacuum), and sports," etc. He says that one of the principal objects of his book is to show how Mr. Darwin "has deluded himself, and perhaps others, by a constant abuse of figurative language." "He plays with Nature as he pleases, and makes her do whatsoever he wishes." When we remember that Mr. Darwin defines Nature to be the aggregate of physical forces, we see how, in attributing everything to Nature, he effectually excludes the supernatural.

In his volume of "Lay Sermons, Reviews," etc., Professor Huxley has a very severe critique on M. Flourens's book. He says little, however, in reference to teleology, except in one paragraph, in which we read: "M. Flourens cannot imagine an unconscious selection; it is for him a contradiction in terms." Huxley's answer is, "The winds and waves of the Bay of Biscay have not much consciousness, and yet they have with great care 'selected,' from an infinity of masses of silex, all grains of sand below a cer-tain size and have heaped them by themselves over a great area. . . . A frosty night selects 
the hardy plants in a plantation from among the tender ones as effectually as if the intelligence of the gardener had been operative in cutting the weaker ones down." 1 If this means anything, it means that as the winds and waves of the Bay of Biscay can make heaps of sand, so similar unconscious agencies can, if you only give them time enough, make an elephant or a man; for this is what Mr. Darwin says natural selection has done.

Rev. Walter Mitchell, M. A., Vice-President of the Victoria Institute.

The Victoria Institute, or Philosophical Society of Great Britain, under the presidency of the Earl of Shaftesbury, includes among its members many of the dignitaries of the Church of England, and a large number of distinguished nien of different professions and denominations. Its principal object is, "To investigate fully and impartially the most important questions of philosophy and science, but more especially those that bear on the great truths revealed in Holy Scripture, with the view of defending these truths against the opposition of Science, falsely so called." The

1 Lay Sermons, p. 347. 
Institute holds bi-monthly meetings, at which papers are read on some important topic, and then submitted to criticism and discussion. These papers, many of which are very elaborate, are published in the Transactions of the Institute, together with a full report of the discussions to which they gave rise. Six volumes, replete with valuable and varied information, have already been published.

Very considerable latitude of opinion is allowed. Hence we find in the Transactions, papers for and against evolution, - for and against Darwinism. It would be easy to quote extracts, pertinent to our subject, more than enough to fill a volume much larger than the present. We must content ourselves with a few citations from the discussion on a paper in favor of the credibility of Darwinism, ${ }^{1}$ and another in favor of the doctrine of evolution. ${ }^{2}$ In summing up the debates on these two topics, the chairman, Rev. Walter Mitchell, presented with great clearness and force his reasons for regarding Darwinism as incredible and impossible. In his protracted remarks he contrasts

1 The Credibility of Darwinism. By George Warington, Esq., F. C. S., M. V. I.

${ }^{2}$ On certain Analogies between the Methods of Deity in Nature and Revelation. By Rev. G. E. Henslow, M. A., F. L. S., M. V.I. 
the Scriptural doctrine, that of the Vestiges of Creation, and that of Darwin on the origin of species. He thus states the doctrine of the Bible on the subject: "If," he says, "science be another name for real knowledge ; if science be the pursuit of sound wisdom; if science be the pursuit of truth itself; I say that man has no right to reject anything that is true because it savors of God. Well, what is this hypothesis - older than that of Darwin which does, and does alone, account for all the observed facts, or all that which we can read, recorded in the book of Nature? It is, that God created all things very good; that $\mathrm{He}$ made every vegetable after its own kind; that He made every animal after its own kind; that He allowed certain laws of variation, but that $\mathrm{He}$ has ordained strict, though invisible and invincible barriers, which prevent that variation from running riot, and which includes it within strict and well defined limits. This is a hypothesis which will account for all that we have learnt from the works of Nature. It admits an intelligent Being as the Author of all the works of creation, animate as well as inanimate; it leaves no mysteries in the animate world unaccounted for. There is one thing 
which the animate, as well as the inanimate world declares to man, one thing everywhere plainly recorded, if we will only read it, and that is the impress of design, the design of infinite wisdom. Any theory which comes in with an attempt to ignore design as manifested in God's creation, is a theory, I say, which attempts to dethrone God. This the theory of Darwin does endeavor to do. If asked how our old theory accounts for such uniformity of design in the midst of such perplexing variety as we find in nature, we reply, that this can only be accounted for on one admission, that the whole is the work of one Author, built according, as it were, to one style; that it represents the unity of one mind with the infinite power of adapting all its works in the most perfect manner for the uses for which they were created." "Whewell has boldly maintained, and he has never been controverted, that all real advances in the sciences of physiology and comparative anatomy, such as that made by Harvey in discovering the circulation of the blood, - have been made by those who not only believed in the existence of design everywhere manifested in the animate world, but were led by that belief to make their discoveries." 
When discussing the paper of Mr. Henslow on evolution, he says: "In speaking of this paper I must commend the exceeding reverent tone in which the author has discussed the subject, and I should like to see all such subjects discussed in a similar tone. The view which Mr. Henslow brings forward, however, does not appear to be a very original one. It was the first view ever brought forward on the doctrine of evolution, and I was the first one to point out that the whole doctrine was one of retrograde character. The whole tone and character of this paper, except that which relates to the attributes and moral government of God, ${ }^{1}$ is nothing more or less than the same view of the doctrine of evolution which created such a sensation in this country when that famous book came out, 'The Vestiges of Creation.' So far as I can understand the arguments of Mr. Darwin, they have simply been an endeavor to eject out of the idea of evolution the personal work of the Deity. His whole endeavor has been to push the Creator farther and farther back out of view. The

1 The second part of Mr. Henslow's paper coneerns "the methods of the Deity as revealed to us in the Bible." The falme is substantially true of his work, The Theory of Eunlution. 
most laborious part of Darwin's attempt at reasoning, - for it is not true reasoning, - the most laborious part of his logic and reasoning, is intended to eliminate, as perfectly as any of the atheistical authors have endeavored to do, the idea of design. Now, setting revelation aside, the manner in which the unknown author of the 'Vestiges of Creation' treated this subject, satisfactorily showed that the doctrine of evolution was not in itself an atheistical doctrine, nor did it deny the existence of design. So far as I could understand and make out, having carefully read the book at the time it came out and afterwards, and having carefully analyzed and compared it and Mr. Darwin's book with each other, so far as I could understand it, the doctrine of the author of the 'Vestiges of Creation' was simply, that God created all things, and that when He created matter $\mathrm{He}$ impressed on it certain laws; that matter, being evolved according to those laws, should produce beings and organs mutually adapted to one another and to the world; and that every successive development which should be produced was essentially foreseen, foreknown, and predetermined by the Deity. His idea, for iustance, of the evolution 
of an eye from a more simple organ was that the ultimate eye - man's eye, for instance was to be a perfect optical instrument, and that its perfection depended on the previous design by the Creator, that at a certain period it should appear in a body quite adapted for its purposes. There is one question, - and not the only one, but we must consider it as an important question, - whether you can maintain a doctrine of evolution which shall not be atheistical, and which shall admit the great argument of design? That is one thing; but the next thing is, does such a doctrine as that accord either with revelation or with the facts of science? I do not believe that it can be made to agree with what we believe to be the revealed Word of God, and I do not believe that it has in the least degree been proved that the doctrine is consistent with sound science."

As to Mr. Darwin's theory, it is obvious from the passages already quoted that he considers its characteristic feature is not evolution, nor even natural selection, but the denial of teleology, or of intelligent control. Mr. Darwin admits the original creation of one or a few forms of life ; and Mr. Mitchell, in his comments on Mr. Warington's defence of his theory, 
asks, "Why am I to limit the work of the Creator to the simultaneous or successive creations of ten or twelve commencements of the animate creation? Why, simply for the purpose of evading the evidence of design as manifested in the adaptation of all the organs of every animate creature to its wants, which can only be done by so incredible an hypothesis as that of Mr. Darwin. I say fearlessly, that any hypothesis which requires us to admit that the formation of such complex organs as the eye, the ear, the heart, the brain, with all their marvellous structures and mechanical adaptations to the wants of the creatures possessing them, so perfectly in harmony, too, with the laws of inorganic matter, affords no evidence of design; that such structures could be built up by gradual chance improvements, perpetuated by the law of transmission, and perfected by the destruction of creatures less favorably endowed, is so incredible, that I marvel to find any thinking man capable of adopting it for a single moment." It is useless to multiply quotations. Darwinism is never brought up either formally or incidentally, that its exclusion of design in the formation of living organisms is not urged as the main objection against the whole theory. 


\section{Principal Dawson.}

Dr. Dawson, as we are informed, is regarded as the first palæontologist, and among the first geologists, in America. In his "Story of Earth and Man," "he passes in review the several geological periods recognized by geologists; describes as far as knowable the distribution of land and water during each period, and the vegetable and animal productions by which they were distinguished. His book from beginning to end is anti-Darwinian. In common with other naturalists, his attention is directed principally to the doctrine of evolution, which he endeavors to prove is utterly untenable. That Mr. Darwin's theory excludes teleology is everywhere assumed as an uncontroverted and uncontrovertible fact. "The evolutionist doctrine," he says, "is itself one of the strangest phenomena of humanity. It existed, and most naturally, in the oldest philosophy and poetry, in connection with the crudest and most uncritical attempts of the

1 The Slory of Earlh and Man. By J. W. Dawson, LL. D., F. R. S., F. G. S.; Principal and Vice-Chancellor of MicGill University, Montreal. Author of Archaia, Acadian Geology, ets. Second edition. London, 1873, pp. 397. 
human mind to grasp the system of nature; but that in our day a system destitute of any shadow of proof, and supported merely by vague analogies and figures of speech, and by the arbitrary and artificial coherence of its own parts, should be accepted as philosophy, and should find able adherents to string on its thread of hypotheses our vast and weighty stores of knowledge, is surpassingly strange. . . . In many respects these speculations are important, and worthy the attention of thinking men. They seek to revolutionize the religious belief of the world, and if accepted would destroy most of the existing theology and philosophy. They indicate tendencies among scientific thinkers, which, though probably temporary, must, before they disappear, descend to lower strata, and reproduce themselves in grosser forms, and with most serious effects on the whole structure of society. With one class of minds they constitute a sort of religion, which so far satisfies the craving for truth higher than those which relate to immediate wants and pleasures. With another and perhaps larger class, they are accepted as affording a welcome deliverance from all scruples of conscience and fears of a hereafter. In the 
domain of science evolutionism has like tendencies. It reduces the position of man, who becomes a descendant of inferior animals, and a mere term in a series whose end is unknown. It removes from the study of nature the ideas of final cause and purpose; and the evolutionist, instead of regarding the world as a work of consummate plan, skill, and adjustment, approaches nature as he would a chaos of fallen rocks, which may present forms of castles, and grotesque profiles of men and animals, but they are all fortuitous and without significance." (pp. 317, 318)

"Taking, then, this broad view of the subject, two great leading alternatives are presented to us. Either man is an independent product of the will of a Higher Intelligence, acting directly or through the laws and materials of his own institution and production, or he has been produced by an unconscious evolution from lower things. It is true that many evolutionists, either unwilling to offend, or not perceiving the logical consequences of their own hypothesis, endeavor to steer a middle course, and to maintain that the Creator has proceeded by way of evolution. But the bare, hard logic of Snencer, the greatest English 
authority on evolution, leaves no place for this compromise, and shows that the theory, carried out to its legitimate consequences, excludes the knowledge of a Creator and the possibility of his work. We have, therefore, to choose between evolution and creation, bearing in mind, however, that there may be a place in nature for evolution, properly limited, as well as for other things, and that the idea of creation by no means excludes law and second causes." (p. 321)

"It may be said, that evolution may be held as a scientific doctrine in connection with a modified belief in creation. The work of actual creation may have been limited to a few. elementary types, and evolution may have done the rest. Evolutionists may still be theists. We have already seen that the doctrine, as carried out to its logical consequences, excludes creation and theism. It may, however, be shown that even in its more modified form, and when held by men who maintain that they are not atheists, it is practically atheistic, because excluding the idea of plan and design, and resolving all things into the action of unintelligent forces. It is necessary to observe this, because it is the half-way-evolutionism, 
which professes to have a creator somewhere behind it, that is most popular; though it is, if possible, more unphilosophical than that which professes to set out with absolute and determined nonentity, or from self-existing stardust containing all the possibilities of the universe."

In reference to the objection of evolutionists, that the origin of every new species, on the theistic doctrine, supposes "a miracle," an intervention of the divine efficiency without the agency of second causes; Principal Dawson asks, "What is the actual statement of the theory of creation as it may be held by a modern man of science? Simply this: that all things have been produced by the Supreme Creative will, acting either directly, or through the agency of the forces and material of his own production." (p. 340)

He thus sums up his argument against the doctrine of evolution, specially in its application to man: "Finally, the evolutionist picturc wants some of the fairest lineaments of humanity, and cheats us with the semblance of man without the reality. Shave and paint your ape as you may, clothe him and set him up upon his feet, still he fails greatly of the ' hu- 
man form divine;' and so it is with him morally and spiritually as well. We have seen that he wants the instinct of immortality, the love of God, the mental and spiritual power of exercising dominion over the earth. The very agency by which he is evolved is of itself subversive of all these higher properties; the struggle for existence is essentially selfish, and, therefore, degrading. Even in the lower animals, it is a false assumption that its tendency is to elevate; for animals, when driven to the utmost verge of the struggle for life, become depauperated and degraded. The dog which spends its life in snarling contention with its fellow curs for insufficient food, will not be a noble specimen of its race. God does not so treat his creatures. There is far more truth to nature in the doctrine which represents Him as listening to the young ravens when they cry for food. But as applied to man, the theory of the struggle for existence, and survival of the fittest, though the most popular phase of evolutionism at present, is nothing less than the basest and most horrible of superstitions. It makes man not merely carnal but devilish. It takes his lowest appetites and propensities, and makes them his God and Creator. His 
higher sentiments and aspirations, his selfdenying philanthropy, his enthusiasm for the good and true, all the struggles and sufferings of heroes and martyrs, not to speak of that self-sacrifice which is the foundation of Christianity, are, in the view of the evolutionist, mere loss and waste, failure in the struggle of life. What does he give us in exchange? An endless pedigree of bestial ancestors, without one gleam of high and holy tradition to enliven the procession; and for the future, the prospect that the poor mass of protoplasm, which constitutes the sum of our being, and which is the sole gain of an indefinite struggle in the past, must soon be resolved again into inferior animals or dead matter. That men of thought and culture should advocate such a philosophy, argues either a strange mental hallucination, or that the higher spiritual nature has been wholly quenched within them. It is one of the saddest of many sad spectacles which our age presents." (p. 395)

\section{Relation of Darwinism to Religion.}

The consideration of that subject would lead into the wide field of the relation between science and religion. Into that field we lack com- 
petency and time to enter; a few remarks, however, on the subject may not be out of place. Those remarks, we would fain make in a humble way irenical. There is need of an Irenicum, for the fact is painfully notorious that there is an antagonism between scientific men as a class, and religious men as a class. Of course this opposition is neither felt nor expressed by all on either side. Nevertheless, whatever may be the cause of this antagonism, or whoever are to be blamed for it, there can be no doubt that it exists and that it is an evil.

The first cause of the alienation in question is, that the two parties, so to speak, adopt different rules of evidence, and thus can hardly avoid arriving at different conclusions. To understand this we must determine what is meant by science, and by scientific evidence. Science, according to its etymology, is simply knowledge. But usage has limited its meaning, in the first place, not to the knowledge of facts or phenomena, merely, but to their causes and relations. It was said of old, "ö $\tau \iota$ scientiæe

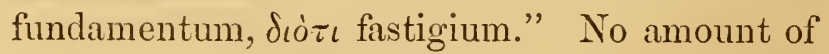
materials would constitute a building. They must be duly arranged so as to make a sym- 
metrical whole. No amount of disconnected data can constitute a science. Those data must be systematized in their relation to each other and to other things. In the second place, the word is becoming more and more restricted to the knowledge of a particular class of facts, and of their relations, namely, the facts of nature or of the external world. This usage is not universal, nor is it fixed. In Germany, especially, the word Wissenschaft is used of all kinds of ordered knowledge, whether transcendental or empirical. So we are accustomed to speak of mental, moral, social, as well as of natural science. Nevertheless, the more restricted use of the word is very common and very influential. It is important that this fact should be recognized. In common usage, a scientific man is distinguished specially from a metaphysician. The one investigates the phenomena of matter, the other studies the phenomena of mind, according to the old distinction between physics and metaphysics. Science, therefore, is the ordered knowledge of the phenomena which we recognize through the senses. A scientific fact is a fact perceived by the senses. Scientific evidence is evidence addressed to the senses. At one of the meetings of the Victoria 
Institute, a visitor avowed his disbelief in the existence of God. When asked, what kind of evidence would satisfy him ? he answered, Just such evidence as I have of the existence of this tumbler which I now hold in my hand. The Rev. Mr. Henslow says, "By science is meant the investigation of facts and phenomena recognizable by the senses, and of the causes which have brought them into existence." 1 This is the main root of the trouble. If science be the knowledge of the facts perceived by the senses, and scientific evidence, evidence addressed to the senses, then the senses are the only sources of knowledge. Any conviction resting on any other ground than the testimony of the senses, must be faith. Darwin admits that the contrivances in nature may be accounted for by assuming that they are due to design on the part of God. But, he says, that would not be science. Haeckel says that to science matter is eternal. If any man chooses to say, it was created, well and good; but that is a matter of faith, and faith is imagination. Ulrici quotes a distinguished German physiolo-

1 Science and Scripture not Antagonistic, because Distinct in their Spheres of Thought. A Lecture, by Rev. George Henslow, M. A., F. L. S., F. G. S. London, 1873, p. 1. 
gist who believes in vital, as distinguished from physical forces; but he holds to spontineous generation, not, as he admits, because it has been proved, but because the admission of any higher power than nature is unscientific.'

It is inevitable that minds addicted to scientific investigation should receive a strong bias to undervalue any other kind of evidence except that of the senses, $i$. e., scientific evidence. We have seen that those who give themselves up to this tendency come to deny God, to deny mind, to deny even self. It is true that the great majority of men, scientific as well as others, are so much under the control of the laws of their nature, that they cannot go to this extreme. The tendency, however, of a mind addicted to the consideration of one kind of evidence, to become more or less insensible to other kinds of proof, is undeniable. Thus even Agassiz, as a zoölogist and simply on zoölogical grounds, assumed that there were several zones between the Ganges and the Atlantic Ocean, each having its own flora and fauna, and inhabited by races of men, the same in kind, but of different origins. When told by the comparative philologists that this was

1 Gott und Natur, p. 200. 
impossible, because the languages spoken through that wide region, demonstrated that its inhabitants must have had a common descent, he could only answer that as ducks quack everywhere, he could not see why men should not everywhere speak the same language.

A still inore striking illustration is furnished by Dr. Lionel Beale, the distinguished English physiologist. He has written a book of three hundred and eighty-eight pages for the express purpose of proving that the phenomena of life, instinct, and intellect cannot be referred to any known natural forces. He avows his belief that in nature " mind governs matter," and "in the existence of a never-changing, all-seeing, powerdirecting and matter-guiding Omnipotence." He avows his faith in miracles, and "those miracles on which Christianity is founded." Nevertheless, his faith in all these points is provisional. He says that a truly scientific man, " if the maintenance, continuity, and nature of life on our planet should at some future time be fully explained without supposing the existence of any such supernatural omnipotent influence, would be bound to receive the new explana- 
tion, and might abandon the old conviction." 1 That is, all evidence of the truths of religion not founded on nature and perceived by the senses, amounts to nothing.

Now as religion does not rest on the testimony of the senses, that is on scientific evidence, the tendency of scientific men is to ignore its claims. We speak only of tendency. We rejoice to know or believe that in hundreds or thousands of scientific men, this tendency is counteracted by their consciousness of manhood - the conviction that the body is not the man, - by the intuitions of the reason and the conscience, and by the grace of God. No class of men stands deservedly higher in public estimation than men of science, who, while remaining, faithful to their ligher nature, have enlarged our knowledge of the wonderful woriks of God.

A second cause of the alienation between science and religion, is the failure to make the due distinction between facts and the explanation of those facts, or the theories deduced from them. No sound minded man disputes

1 Protoplasm; or, Matter and Life. By Lionel S. Beale, M. B., F. R. S. Third edition. London \& Philadelphia, 1874, p. 345 ; and the whole chapter on Design. 
any scientific fact. Religirus men believe with Agassiz that facts are sacred. They are revelations from God. Christians sacrifice to them, when duly authenticated, their most cherished convictions. That the earth moves, no religious man doubts. When Galileo made that great discovery, the Church was right in not yielding at once to the evidence of an experiment which it did not understand: But when the fact was clearly established, no man sets up his interpretation of the Bible in opposition to it. Religious men admit all the facts connected with our solar systemi ; - all the facts of geology, and of comparative anatomy, and of biology. Ought not this to satisfy scientific men? Must we also admit their explanations and inferences? If we admit that the human embryo passes through various phases, must we admit that man was once a fish, then a bird, then a dog, then an ape, and finally what he now is? If we admit the similarity of structure in all vertebrates, must we admit the evolution of one from another, and all from a primordial germ? It is to be remembered that the facts are from God, the explanation from men; and the two are often as far apart as Heaven and its antipode. 
These human explanations are not only without authority, but they are very mutable. They change not only from generation to generation, but almost as often as the phases of the moon. It is a fact that the planets move. Once it was said that they were moved by spirits, then by vortexes, now by self-evolved forces. It is hard that we should be called upon to change our faith with every new moon. The same man sometimes propounds theories almost as rapidly as the changes of the kaleidoscope. The amiable Sir Charles Lyell, England's most distinguished geologist, has published ten editions of his "Principles of Geology," which so differ as to make it hard to believe that it is the work of the same mind. "In all the editions up to the tenth, he looked upon geological facts and geological phenomena as proving the fixity of species and their special creation in time. In the tenth edition, just published, he announces his change of opinion on this subject and his conversion to the doctrine of development by law." 1 "In the eighth edition of his work," says Dr. Bree, "Sir Charles Lyell, the Nestor of geologists, to

1 Fallacies in the Hypothesis of Mr. Darwin, by C. R. Bree, M. D., F. Z. S. London, 1872, p. 230. 
whom the present generation is more indebted than to any other for all that is known of geology in its advanced stage, teaches that species have a real existence in nature, and that each was endowed at the time of its creation with the attributes and organization by which it is now distinguished." The change on the part of this eminent geologist, it is to be observed, is a mere change of opinion. There was no change of the facts of geology between the publication of the eighth and of the tenth edition of his work, neither was there any change in his knowledge of those facts. All the facts relied upon by evolutionists, have long been familiar to scientific men. The whole change is a subjective one. One year the veteran geologist thinks the facts teach one thing, another year he thinks they teach another. It is now the fact, and it is feared it will continue to be a fact, that scientific men give the name of science to their explanations as well as to the facts. Nay, they are often, and naturally, more zealous for their explanations than they are for the facts. The facts are God's, the explanations are their own.

The third cause of the alienation between religion and science, is the bearing of scientific 
men towards the men of culture who do not belong to their own class. When we, in such connections, speak of scientific men, we do not mean men of science as such, but those only who avow or manifest their hostility to religion. There is an assumption of superiority, and often a manifestation of contempt. Those who call their logic or their conjectures into question, are stigmatized as narrow-minded, bigots, old women, Bible worshippers, etc.

Professor Huxley's advice to metaphysicians and theologians is, to let science alone. This is his Irenicum. But do he and his associates let metaphysics and religion alone? They tell the metaphysician that his vocation is gone; there is no such thing as mind, and of course no mental laws to be established. Metaphysics are merged into physics. Professor Huxley tells the religious world that there is overwhelming and crushing evidence (scientific evidence, of course) that no event has ever Gccurred on this earth which was not the effect of natural causes. Hence there have been no miracles, and Christ is not risen. ${ }^{1}$ He says that

1 When Professor Huxley says, as quoted above, that he does not deny the possibility of miracles, he must use the word miracle in a sense peculiar to himself. 
the doctrine that belief in a personal God is necessary to any religion worthy of the name, is a mere matter of opinion. Tyndall, Carpenter, and Henry Thompson, teach that prayer is a superstitious absurdity; Herbert Spencer; whom they call their "great philosopher," $i$. e., the man who does their thinking, labors to prove that there cannot be a personal God, or human soul or self; that moral laws are mere "generalizations of utility," or, as Carl Vogt says, that self respect, and not the will of God, is the ground and rule of moral obligation. If any protest be made against such doctrines, we are told that scientific truth cannot be put down by denunciation (or as Vogt says, by barking). So doubtless the Pharisees, when our blessed Lord called them hypocrites and a generation of vipers, and siid: "Ye compass sea and land to make one proselyte; and when he is made, ye make him twofold more the child of hell than yourselves," douhtless thought that that was a poor way to refuic their theory, that holiness and salvation were to be secured by church-membership and church-rites. Nevertheless, as those words were the words of Christ, they were a thunderbolt which reverberates through all time and 
space, and still makes Pharisees of every name - and nation tremble. Huxley's Irenicum will not do. Men who are assiduously poisoning the fountains of religion, morality, and social order, cannot be let alone.

Haeckel's Irenicum amounts to much the same as that of Professor Huxley. He forbids the right to speak on these vital subjects, to all who are not thoroughly versed in biology, and who are not entirely emancipated from the trammels of their long cherished traditional beliefs. ${ }^{1}$ 'This, as the whole context shows, means that a man in order to be entitled to be heard on the evolution theory, must be willing to renounce his faith not only in the Bible, but in

1 Jenaer Literaturzeitung, January 3, 1874. In this number there is a notice by Doctor Haeckel of two books, - Descendenzlehre und Darwinismus, von Osear Schmidt, Leipzig, 1873; and Die Fòrtschritte des Darwinismus, von J. W. Spengel, Cöln and Leipzig, 1874; in which he says: "Erstens, um in Sachen der Descendenz-Theorie mitreden zu können, ein gewisser Grad von tieferer biologischer (sowohl morphologischer als physiologischer) Bildung unentbelırlich, den die meisten von jenen Auctoren (the opposers of the theory) nicht besitzen. Zweitens ist für ein klares und zutreffendes Urtheil in diesem Sachen eine rücksichtslose Hingabe an vernunftgemässe Erkenntniss und eine dadurch bedingte Resignation auf uralte, liebgewordene und tief vererbte Vorurtheile erforderlich, zu welcher sich die wenigsten entschliesen können." 


\section{God, in the soul, in a future life, and become a} monistic materialist. ${ }^{1}$

It is very reasonable that scientific men, in common with lawyers and physicians and other professional men, should feel themselves entitled to be heard with special deference on

${ }^{1}$ In his Natürlische Schöpfungsgeschichte, Haeckel is still more exclusive. When he comes to answer the objections to the evolution, or, as he commonly calls it, the descendence theory, he disnisses the objections derived from religion, as unworthy of notice, with the remark that all Glaube ist Aberglaube; all faith is superstition. The objections from a priori, or intuitive truths, are disposed of in an equally summary manner, by denying that there are any such truths, and asserting that all our knowledge is from the senses. The objection that so many distinguished naturalists reject the theory, he considers more at length. First, many have grown old in another way of thinking and cannot be expected to change. Second, many are collectors of facts, without studying their relations, or are destitute of the genius for generalization. No amount of material makes a building. Others, again, are specialists. It is not enough that a man should be versed in one department; he must be at home in all : in Botany, Zoölogy, Comparative Anatomy, Biology, Geology, and Palæontology. He must be able to survey the whole field. Fourthly, and mainly, naturalists are generally lamentably deficient in philosophieal culture and in a philosophical spirit. "The immovable edifice of the true, monistic science, or what is the same thing, natural science, can only arise through the most intimate interaction and mutual interpenetration of philosophy and observation (Philosophie und Empirie)." pp. 638-641. It is only a select few, therefore, of learnerl and philosophical monistic materialists, who are entitled to be heard on questions of the highest moment to every individual man, and to buman society. 
subjects belonging to their respective departments. This deference no one is disposed to deny to men of science. But it is to be remembered that no department of human knowledge is isolated. One runs into and overlaps another. We have abundant evidence that the devotees of natural science are not willing to confine themselves to the department of nature, in the common sense of that word. They not only speculate, but dogmatize, on the highest questions of philosophy, morality, and religion. And further, admitting the special claims to deference on the part of scientific men, other men liave their rights. They have the right to judge of the consistency of the assertions of men of science and of the logic of their reasoning. They have the right to set off the testimony of one or more experts against the testimony of others; and especially, they have the right to reject all speculations, hypotheses, and theories, which come in conflict with well established truths. It is ground of profound gratitude to God that He has given to the human mind intuitions which are infallible, laws of belief which men cannot disregard any more than the laws of nature, and also convictions produced by the Spirit of 
God which no sophistry of man can weaken. These are barriers which no man can pass without plunging into the abyss of outer darkness.

If there be any truth in the preceding remarks, then it is obvious that there can be no harmony between science and religion until the evils referred to be removed. Scientific men must come to recognize practically, and not merely in words, that there are other kinds of evidence of truth than the testimony of the senses. They must come to give due weight to the testimony of consciousness, and to the intuitions of the reason and conscience. They must cease to require the deference due to established facts to be paid to their speculations and explanations. And they must treat their fellow-men with due respect. The Pharisees said to the man whose sight had been restored by Christ, "Thou wast altogether born in sin, and dost thou teach us!" Men of science must not speak thus. They must not say to every objector, Thou art not scientific, and therefore hast no right to speak. The true Irenicum is for all parties to give due heed to such words as these, "If any man would be wise, let him become a fool, that he may be wise;" or these, "Be converted, and become 
as little children;" or these, "The Spirit of Truth shall guide you in all truth." We are willing to hear this called cant. Nevertheless, these latter words fell from the lips of Him who spake as never man spake.

So much, and it is very little, on the general question of the relation of science to religion. But what is to be thought of the special relation of Mr. Darwin's theory to the truths of natural and revealed religion? We have already seen that Darwinism includes the three elements, evolution, natural selection, and the denial of design in nature. These points, however, camnot now be considered separately.

It is conceded that a man may be an evolutionist and yet not be an atheist and may admit of design in nature. But we cannot see how the theory of evolution can be reconciled with the declarations of the Scriptures. Others may see it, and be able to reconcile their allegiance to science with their allegiance to the Bible. Professor Huxley, as we have seen, pronounces the thing impossible. As all error is antagonistic to truth, if the evolution theory be false, it must be opposed to the truths of religion so far as the two come into contact. Mr. Henslow, indeed, says Science and Religion are not antag- 
onistic because they are in different spheres of thought. This is often said by men who do not admit that there is any thought at all in religion; that it is merely a matter of feeling. The fact, however, is that religion is a system of knowledge, as well as a state of feeling. The truths on which all religion is founded are drawn within the domain of science, the nature of the first cause, its relation to the world, the nature of second causes, the origin of life, anthropology, including the origin, nature, and destiny of man. Religion has to fight for its life against a large class of scientific men. All attempts to prevent her exercising her right to be heard are unreasonable and vain.

It should be premised that this paper was written for the single purpose of answering the question, What is Darwinism? The discussion of the merits of the theory was not within the scope of the writer. What follows, therefore, is to be considered only in the light of a practical conclusion.

1. The first objection to the theory is its primâ facie incredibility. That a single plant or animal should be developed from a mere cell, is such a wonder, that nothing but daily observation of the fact could induce any man to be- 
lieve it. Let any one ask himself, suppose this fuct was not thus familiar, what amount of speculation, of arguments from analogies. possibilities, and probabilities, could avail to produce conviction of its truth. But who can believe that all the plants and animals which have ever existed upon the face of the earth, have been evolved from one such germ? This is Darwin's doctrine. We are aware that this apparent impossibility is evaded by the believers in spontaneous generation, who hold that such germ cells may be produced anywhere and at all times. But this is not Darwinism. Darwin wants us to believe that all living things, from the lowly violet to the giant redwoods of California, from the microscopic animalcule to the.Mastodon, the Dinotherium, - monsters the very description of which fill us with horror, - bats with wings twenty feet in breadth, flying dragons, tortoises ten feet high and eighteen feet long, etc., etc., came one and all from the same primordial germ. This demand is the more unreasonable when we remember that these living creatures are not only so different, but are, as to plants and animals, directly opposed in their functions. The function of the plant, as biologists express it, is 
to produce force, that of the animal to expend it. The plant, in virtue of a power peculiar to itself, which no art or skill of man can imitate, transmutes dead inorganic matter into organic matter, suited to the sustenance of animal life, and without which animals cannot live. The gulf, therefore, between the plant and animal would seem to be impassable.

Further, the variations by which the change of species is effected are so trifling as often to be imperceptible, and their accumulation of them so slow as to evade notice, - the time requisite to accomplish any marked change must be counted by millions, or milliards of years. Here is another demand on our credulity. The apex is reached when we are told that all these transmutations are effected by chance, that is, without purpose or intention. <Taking all these things into consideration, we think it may, with moderation, be said, that a more absolutely incredible theory was never propounded for acceptance among men.)

2. There is no pretence that the theory can be proved. Mr. Darwin does not pretend to prove it. He admits that all the facts in the case can be accounted for on the assumption of divine purpose and control. All that he claims 
for his theory is that it is possible. His mode of arguing is that if we suppose this and that, then it may have happened thus and so. Amiable and attractive as the man presents himself in his writings, it rouses indignation, in one class at least of his readers, to see him by such a mode of arguing reaching conclusions which are subversive of the fundamental truths of religion.

3. Another fact cannot fail to attract attention. When the theory of evolution was propounded in 1844 in the "Vestiges of Creation," it was universally rejected; when proposed by Mr. Darwin, less than twenty years afterward, it was received with acclamation. Why is this? The facts are now what they were then. They were as well known then as they are now. The theory, so far as evolution is concerned, was then just what it is now. How then is it, that what was scientifically false in 1844 is scientifically true in 1864? When a drama is introduced in a theatre and universally condemned, and a little while afterward, with a little change in the scenery, it is received with rapturous applause, the natural conclusion is, that the change is in the audience and not in the drama. 
There is only one cause for the fact referred to, that we can think of. The "Vestiges of Creation" did not expressly or effectually exclude design. Darwin does. This is a reason assigned by the most zealous advocates of his theory for their adoption of it. This is the reason given by Büchner, by Haeckel, and by Vogt. It is assigned also in express terms by Strauss, the announcement of whose death has diffused a feeling of sadness over all who were acquainted with his antecedents. In his last work, "The Old Faith and the New," he admits " that Darwin's doctrine is a mere hypothesis; that it leaves the main points unexplained (Die Hupt- und Cardinal-punkte noch unerklärt sind); nevertheless, as he has shown how miracles may be excluded, he is to be applauded as one of the greatest benefactors of the human race." (p. 177) By "Wunder," or miracle, Strauss means any event for which natural causes are insufficient to account. "We philosophers and critical theologians," he says, " have spoken well when we decreed the abolition of miracles; but our decree (machtspruch) remained without effect, because we could not show them to be unnecessary, inasmuch as we were unable to indicate any nat- 
ural force to take their place. Darwin has provided or indicated this natural force, this process of nature; he has opened the door through which a happier posterity may eject miracles forever." Then follows the sentence just quoted, "He who knows what hangs on miracle, will applaud Darwin as one of the greatest benefactors of the human race." With Strauss and others of his class, miracles and design are identical, because one as well as the other assumes supernatural agency. $\mathrm{He}$ quotes Helmholtz, who says, "Darwin's theory, that adaptation in the formation of organisms may arise without the intervention of intelligence, by the blind operation of natural law ;" and then adds, "As Helmholtz distinguishes the English naturalist as the man who has banished design from nature, so we have praised him as the man who has done away with miracles. Both mean the same thing. ${ }^{1}$ Design is the miracle-worker in nature, which has put the world upside down; or as Spinoza says, has placed the last first, the effect for the cause, and thus destroyed the very idea of nature.

1 This short but significant sentence is omitted in the excellent translation of Strauss's book, by Mathilde Blind, republished in New York, by Henry Holt \& Company, 1873. 
Design in nature, especially in the department of living organisms, has ever been appealed to by those who desire to prove that the world is not self-evolved, but the work of an intelligent Creator." (p. 211) On page 175, he refers to those who ridicule Darwin, and yet are so far under the influence of the spirit of the age as to deny miracles or the intervention of the Creator in the course of nature, and says: "Very well; how do they account for the origin of man, and in general the development of the organic out of the inorganic ? Would they assume that the original man as such, no matter how rough and unformed, but still a man, sprang immediately out of the inorganic, out of the sea or the slime of the Nile? They would hardly venture to say that; then they must know that there is only the choice between miracle, the divine hand of the Creator, and Darwin." What an alternative; the Creator or Darwin! In this, however, Strauss is right. To banish design from nature, as is done by Darwin's theory, is, in the language of the Rev. Walter Mitchell, virtually "to dethrone the Creator."

Ludwig Weis, M. D., of Darmstadt, says it is at present "the mode" in Germany (and 
of course in a measure here), to glorify Buddhism. Strauss, he adds, says, "Nature knows itself in man, and in that he expresses the thought which all Idealism and all Materialism make the grand end. To the same effect it is said, 'In Man the All comprehends itself as conscious being (comes to self-consciousness); or, in Man the absolute knowledge (Wissen, the act of knowing) appears in the limits of personality.' This was the doctrine of the Buddhist and of the ancient Chinese." Thus, as Dr. Weis says, "in the nineteenth century of the Christian era, philosophers and scientists have reached the point where the Chinese were two thousand years ago."

The only way that is apparent for accounting for evolution being rejected in 1844, and for its becoming a popular doctrine in 1866 , is, that it happens to suit a prevailing state of mind. It is a fact, so far as our limited knowledge extends, that no one is willing to acknowledge himself, not simply an evolutionist, but an evolutionist of the Darwinian school, who is not either a Materialist by profession, or a disciple of Herbert Spencer, or an advocate of the philosophy of Hume.

There is another significant fact which goes 
to prove that the denial of design, which is the "creative idea" of Darwinism, is the main cause of its popularity and success. Professor Owen, England's greatest naturalist, is a derivationist. Derivation and evolution are convertible terms. Both include the denial that species are primordial, or have each a different origin; and both imply that one species is formed out of another and simpler form. Professor Owen, however, although a derivationist, or evolutionist, is a very strenuous antiDarwinian. He differs from Darwin as to two points. First, as to Natural Selection, or the Survival of the Fittest. He says that is inconsistent with facts and utterly insufficient to account for the origin of species. He refers the origin of species to an inherent tendency to change impressed on them from the beginning. And second, he admits design. $\mathrm{He}$ denies that the succession and origin of species are due to chance, and expresses his belief in the constant operation of creative power in the formation of species from the varied descendants of more generalized forms. ${ }^{1} \mathrm{He}$ believes " that all living things have been produced by such law (of variation) in time, their

1 The Fallacies of Darwinism, by C. R. Bree, M. D., p. 308. 
position and uses in the world having been preordained by the Creator." 1 Professor Owen says he has taught the doctrine of derivation (evolution) for thirty years, but it attracted little attention. As soon, however, as Darwin leaves out design, we have a prairie-fire. A prairie-fire, happily, does not continue very long; and while it lasts, it burns up little else than stubble.

4. All the evidence we have in favor of the fixedness of species is, of course, evidence not only against Darwinism, but agaimst evolution in all its forms. It would seem idle to discuss the question of the mutability of species, until satisfied what species is. This, unhappily, is a question which it is exceedingly diffieult to answer. Not only do the definitions given by scientific men differ almost indefinitely, but there is endless diversity in classification. Think of four hundred and eighty species of humming-birds. Haeckel says that one.naturalist makes ten, another forty, another two hundred, and another one, species of a certain fossil ; and we have just heard that Agassiz had collected eight hundred species of the same fossil animal. Haeckel also says (p. 246), that

1 The Fallacies of Darwinism, p. 305. 
there are no two zoölogists or any two botanists who agree altogether in their classification. Mr. Darwin says, "No clear line of demarcation has yet been drawn between species and sub-species, and varieties." (p. 61) It is absolutely necessary, therefore, that a distinction should be made between artificial and natural species. No man asserts the immutability of all those varieties of plants and animals, which naturalists, for the convenience of classification, may call distinct species. Haeckel, for example, gives a list of twelve species of man. So any one may make fifty species of dogs, or of horses. This is a mere artificial distinction, which amounts to nothing. There is far greater difference between a pouter and a carrier pigeon, than between a Caucasian and a Mongolian. To call the former varieties of the same species, and the latter distinct species, is altogether arbitrary. Nevertheless, notwithstanding the arbitrary classifications of naturalists, it remains true that there are what Professor Dana calls "units" of the organic world. "When individuals multiply from generation to generation, it is but a repetition of the primordial type-idea, and the true notion of the species is 
not in the resulting group, but in the idea or potential element which is the basis of every individual of the group." 1 Dr. Morton's definition of species as "primordial organic forms," agrees with that given by Professor Dana; and both agree with the Bible, which says that God created plants and animals each after its kind. A primordial form is a form which was not evolved out of some other form, but which began to be in the form - subject. to such varieties as we see in the dog, horse, and man in which it continued during the whole period of its existence.

The criteria of these primordial forms or species of nature, are, (1.) Morphological. Animals, however, may approach very nearly in their structure, and yet belong to different species. It is only when the peculiarities of structure are indicative of specialty of design, that they form a safe ground of classification. If the teeth of one animal are formed to fit it to feed on flesh, and those of another to fit it to feed on plants; if one has webbed feet and another not; then, in all such cases, difference of structure proves difference of kind. (2.) Physiological; that is, the internal nature, indicated

1 Bibliotheca Sacra, 1857, p. 861. 
by habits and instincts, furnishes another safe criterion. (3.) Permanent fecundity. The progenitors of the same species reproduce their kind from generation to generation ; the progeny of different species, although nearly allied, do not. It is a fixed law of nature that species never can be annihilated, except by all the individuals included in them dying out; and that new species cannot be produced. Every true species is primordial. It is this fact, that is, that no variety, with the essential characteristics of species, has ever been produced, that forces, as we saw above, Professor Huxley to pronounce Mr. Darwin's doctrine to be an unproved hypothesis. Species continue; varieties, if let alone, always revert to the normal type. It requires the skill and constant attention of man to keep them distinct.

Now that there are such forms in nature, is proved not only from the testimony of the great body of the most distinguished naturalists, but by all the facts in the case.

First, the fact that such species are known to have existed. unchanged, through what geologists consider almost immeasurable periods of time. Palæontologists tell us that Trilobites abounded from the primordial age down to the 
Carbouiferous period, that is, as they suppose, through millions of years. More wonderful still, the little animals whose remains constitute the chalk formations which are spread over large areas of country, and are sometimes a hundred feet thick, are now at work at the bottom of the Atlantic. Principal Dawson tells us, with regard to Mollusks existing in a sub-fossil state in the Post-pliocene clays of Canada, that "after carefully studying about two hundred species, and of some of these, many hundreds of specimens, I have arrived at the conclusion that they are absolutely unchanged. . . . Here again we have an absolute refusal, on the part of all these animals, to admit that they are derived, or have tended to sport into new species." 1

On the previous page he says, "Pictet catalogues ninety-eight species of mammals which inhabited Europe in the Post-glacial period. Of these fifty-seven still exist unchanged, and the remainder have disappeared. Not one can be shown to have been modified into a new form, though some of them have been obliged, 'by changes of temperature and other conditions, to remove into distant and now widely separated regions."

1 The Story of Earth and Man, p. 358. 
A second fact which attests the primordial character and fixedness of species is, that every species as it first appears, is not in a transition state between one form and another, but in the perfection of its kind. Science has indeed discovered an ascending order in creation, which agrees marvellously with that given in the book of Genesis: first, vegetable productions; then the moving creatures in the sea; then terrestrial animals; and finally man. Naturalists, who utterly reject the Scriptures as a divine revelation, speak with the highest admiration of the Mosaic account of the creation, as compared with any other cosmogony of the ancient world. While there is in general an ascending series in these living forms, each was perfect in its kind.

Agassiz says that fishes existed contemporaneously with species of all the invertebrate sub-kingdoms in the Taconic, or sub-Cambrian strata. This is the extreme limit of known geological strata in which life is found to have existed. As the evolution of one species out of another requires, according to Darwin, millions of years, it is out of the question to trace these animals beyond the strata in which their remains are now found. Yet "crabs or lobsters, 
worms, cuttle-fish, snails, jelly-fish, star-fish, oysters, the polyps lived contemporaneously with the first known vertebrate animals that ever came into being - all as clearly defined by unmistakable ordinal or special characters as they are at the present moment." 1

The foot of the horse is considered by zoölogists as " one of the most beautiful contrivances in nature." The remains of this animal found in what is called the Pliocene Period, show the foot to have been as perfect then as it is now.

Mr. Wallace says that man has existed on the earth a hundred thousand years, and that it is probable that he existed four hundred thousand years ago. Of course we do not believe this. We have little faith in the chronology of science. It gives no sure data for the calculation of time, hence we find them differing from four thousand to four hundred thousand years as to the time required for certain formations. The most trustworthy geologists

1 Dr. Bree, p. 275. We presume geologists differ in the terms which they use to designatc strata. Agassiz calls the oldest containing fossil, the sub-Cambrian. Principal Dawson calls the oldest the Laurentian, and places the first vertebrates in the Silurian. This is of no moment as to the argument. 'The important fact is that eacl species is distinct as soon as it appears; and that many have remained to the present time. 
teach that all that is known of the antiquity of man falls within the limits of Biblical chronology. The further, however, Darwinians push back the origin of man, the stronger, as against them, becomes the argument for the immutability of species. The earliest remains of man show that at his first appearance, he was in perfection. The oldest known human skull is that called the "Engis," because found in the cave of Engis in Belgium. Of this skull Professor Huxley says it may have belonged to an individual of one of the existing races of men. Principal Dawson, who has a cast of it, on the same shelf with the skulls of some Algonquin Indians, says it might be taken for the skull of an American Indian. Indeed, Dawson seems to think that these fossil human remains go to show that the earliest men were better developed than any of the extant races.

Thirdly. The historical evidence accessible all goes to prove the immutability of species. The earliest historical records, and the oldest monuments prove that all extant animals were what they now are thousands of years ago.

Fourthly. The fact that hybrids cannot be perpetuated, that no device of man can produce a new species, is proof that God has fixed 
limits which eannot be passed. This Huxley himself admits to be an insuperable objection. So long as it exists, he says, Darwin's doctrine must be content to remain a hypothesis; it cannot pretend to the dignity of a theory. Another fact of like import is that varieties artificially produced, if let alone, uniformly revert to the simple typical form. It is only by the utmost care they can be kept distinet. All the highly prized varieties of horses, cattle, sheep, pigeons, ete., without human control, would be merged each class into one, with only the slight differences occasioned by diversities of climate and other external conditions. If in the sight of man it is important that the words of a book should be kept distinct, it is equally evident that in the sight of God it is no less important that the "units of nature" should not be mixed in inextricable and indistinguishable confusion.

Fifthly. The sudden appearance of new kinds of animals is another fact which Palæontologists urge against the doctrine of evolution. According to the view of geologists great changes have, at remote periods, occurred in the state of the earth. Continents have been submerged and the bottom of the sea raised above 
the surface of the waters. Corresponding changes have occurred in the state of the atmosphere surrounding the globe, and in the temperature of the earth. Accompanying or following these revolutions new classes of plants and animals appear, adapted to the new condition of the earth's surface. Whence do they come? They have, as Dawson expresses it, neither fathers nor mothers. Nothing precedes them from which they could be derived; and nothing of the same kind follows them. They live through their appointed period; and then, in a multitude of cases, finally disappear, and are in their turn followed by new orders or kinds. In other words, the links or connecting forms of this assumed regular succession or derivation are not to be found. This fact is so patent, that Hugh Miller, when arguing against the doctrine of evolution as proposed in the "Vestiges of Creation," says, that the record in the rocks seems to have been written for the very purpose of proving that such evolution is impossible.

We have the explicit testimony of Agassiz, as a Palæontologist, that the facts of geology contradict the theory of the transmutation. of species. This testimony has been repeatedly 
given and in various forms. In the last production of his pen, he says: "As a Palæontologist I have from the beginning stood aloof from this new theory of transmutation, now so widely admitted by the scientific world. Its doctrines, in fact, contradict what the animal forms buried in the rocky strata of our earth tell us of their own introduction and succession upon the surface of the globe." "Let us look now at the earliest vertebrates, as known and recorded in geological surveys. They should, of course, if there is any truth in the transmutation theory, correspond with the lowest in rank or standing. What then are the earliest known vertebrates? They are Selachians (sharks and their allies) and Ganoids (garpikes and the like), the highest of all living fishes, structurally speaking." He closes the article from which these quotations are taken with the assertion, "that there is no evidence of a direct descent of later from earlier species in the geological succession of animals." 1 It will be observed that Agassiz is quoted, not as to matters of theory, but as to matters of fact. The only answer which evolutionists can make to this argument, is the imperfection of the geo-

1 Atlantic Monthly, January, 1874. 
logical record. When asked, Where are the immediate predecessors of these new species? they answer, They have disappeared, or, have not yet been found. When asked, Where are their immediate successors? the answer again is, They have disappeared. ${ }^{1}$ This is an objection which Mr. Darwin, with his usual candor, virtually admits to be unanswerable. We have already seen, that he says, "Every one will admit that the geological record is imperfect; but very few can believe that it is so very imperfect as my theory demands."

Such are some of the grounds on which geologists and palæontologists of the highest rank assert that the theory of evolution has not the slightest scientific basis; and they support their assertion with an amount of evidence of which the above items are a miserable pittance.

Sixthly. There is another consideration of

1 We have heard a story of a gentleman who gave an artist a commission for a historical painting, and suggested as the subject, the Passage of the Israelites over the Red Sea. In due time he was informed that his picture was finished, and was shown by the artist a large canvas painted red. "What is that?" he asked. "Why," says the artist, "that is the Red Sea." "But where are the Israelites?" "Olı, they have passed over." And where are the Egyptians?" "They are under the sea." 
decisive importance. Strauss says, there are three things which have been stumbling-blocks in the way of science. First, the origin of life; second, the origin of consciousness; third, the origin of reason. These are equivalent to the gaps which, Principal Dawson says, exist in the theory of evolution. He states them thus: 1. That between dead and living matter. 2. That between vegetable and animal life. "These are necessarily the converse of each other: the one deoxidizes and accumulates, the other oxidizes and expends." 3. That "between any species of plant or animal, and any other species. It was this gap, and this only, which Darwin undertook to fill up by his great work on the origin of species, but, notwithstanding the immense amount of material thus expended, it yawns as wide as ever, since it must be admitted that no case has been ascertained in which an individual of one species has transgressed the limits between it and another species." 4. "Another gap is between the nature of the animal and the self-conscious, reasoning, and moral nature of man." (pp. 325328)

First, as to the gap between death and life; this is what Dr. Stirling calls the "gulf of all 
gulfs, which Mr. Huxley's protoplasm is as powerless to efface as any other material expedient that has ever been suggested." 1 This gulf Mr. Darwin does not attempt to bridge over. He admits that life owes its origin to the act of the Creator. This, however, the most prominent of the advocates of Darwinism say, is giving up the whole controversy. If you admit the intervention of creative power at one point, you may as well admit it in any other. If life owes its origin to creative power, why not species? If the stupendous miracle of creation be admitted, there is no show of reason for denying supernatural intervention in the operations of nature. Most Darwinians attempt to pass this gulf on the imaginary bridge of spontaneous generation. In other words, they say there is no gulf there. The molecules of matter, in one combination, may as well exhibit the phenomena of life, as in other combinations, any other kind of phenomena. The distinguished Sir William Thomson cannot trust himself to that

1 As Regards Protoplasm in Relation to Professor Huxley's Essay on the Physical Basis of Life. By Dr. James H. Stirling. Sce, also, Physiological Anatomy and Plysiology of Man, by L. S. Beale; also, The Mystery of Life in Reply to Dr. Gull's Attack on the Theory of Vitality. By L. S. Beale, M. D., 1871. 
bridge. "Dead matter," he says, "cannot become living matter without coming under the influence of matter previously alive. This seems to me as sure a teaching of science as the law of gravitation. . . . I am ready to adopt, as an article of scientific faith, true through all space and through all time, that life proceeds from life, and nothing but life." 1 He refers the origin of life on this earth to falling meteors, which bring with them from other planets the germs of living organisms; and from those germs all the plants and animals with which our world is now covered have been derived. Principal Dawson thinks that this was intended as irony. But the whole tone of the address, and specially of the closing portion of it, in which this idea is advanced, is far too serious to admit of such an explanation.

No one can read the address referred to without being impressed, and even awed, by the immensity and grandeur of the field of knowledge which falls legitimately within the domain of science. The perusal of that discourse produces a feeling of humility analogous to the

1 The address delivered by Sir William Thomson, as President of the British Association at its meeting in Edinburgh, 1871. 
sense of insignificance which every man experiences when he thinks of himself as a speck on the surface of the earth, which itself is but a speck in the immensity of the universe. And when a man of mere ordinary culture sees Sir William Thomson surveying that field with a mastery of its details and familiarity with all the recondite methods of its investigation, he feels as nothing in his presence. Yet this great man, whom we cannot help regarding with wonder, is so carried away by the spirit of his class as to say, "Science is bound, by the everlasting law of honor, to face fearlessly every problem which can fairly be brought before it. If a probable solution, consistent with the ordinary course of nature, can be found, we must not invoke an abnormal act of Creative Power." And, therefore, instead of invoking Creative Power, he accounts for the origin of life on earth by falling meteors. How he accounts for its origin in the places whence the meteors came, he does not say. Yet Sir William Thomson believes in Creative Power; and in a subsequent page, we shall quote his explicit repudiation of the atheistic element in the Darwinian theory.

Strauss quotes Dubois-Reymond, a distin- 
guished naturalist, as teaching that the first of these great problems, viz. the origin of life, admits of explanation on scientific ( $i$. e., in his sense, materialistic) principles; and even the third, viz. the origin of reason; but the second, or the origin of consciousness, he says, "is perfectly inscrutable." Dubois-Reymond holds that "the most accurate knowledge of the essential organism reveals to us only matter in motion; but between this material movement and my feeling pain or pleasure, experiencing a sweet taste, seeing red, with the conclusion ' therefore I exist,' there is a profound gulf; and it 'remains utterly and forever inconceivable why to a number of atoms of carbon, hydrogen, etc., it should not be a matter of indifference how they lie or how they move; nor can we in any wise tell how consciousness should result from their concurrent action.' Whether," adds Strauss, "these Verba Magistri are indeed the last word on the subject, time only can tell." I But if it is inconceivable, not to say absurd, that sense-consciousness should consist in the motion of molecules of matter, or be a function of such molecules, it can hardly be less absurd to account for

1 The Ord Faith and the New. Prefatory Postscript, xxi. 
thought, conscience, and religious feeling and belief on any such hypothesis. It may be said that Mr. Darwin is not responsible for these extreme opinions. That is very true. Mr. Darwin is not a Monist, for in admitting creation, he admits a dualism as between God and the world. Neither is he a Materialist, inasmuch as he assumes a supernatural origin for the infinitesimal modicum of life and intelligence in the primordial animalcule, from which without divine purpose or agency, all living things in the whole history of our earth have descended. All the innumerable varieties of plants, all the countless forms of animals, with all their instincts and faculties, all the varieties of men with their intellectual endowments, and their moral and religious nature, have, according to Darwin, been evolved by the agency of the blind, unconscious laws of nature. This infinitesimal spark of supernaturalism in Mr. Darwin's theory, would inevitably have gone out of itself, had it not been rudely and contemptuously trodden out by his bolder, and more logical successors.

The grand and fatal objection to Darwinism is this exclusion of design in the origin of species, or the production of living organisms 
By design is meant the intelligent and voluntary selection of an end, and the intelligent and voluntary choice, application, and control of means appropriate to the accomplishment of that end. That design, therefore, implies intelligence, is involved in its very nature. No man can perceive this adaptation of means to the accomplishment of a preconceived end, without experiencing an irresistible conviction that it is the work of mind. No man does doubt it, and no man can doubt it. Darwin does not deny it. Haeckel does not deny it. No Darwinian denies it. What they do is to deny that there is any design in nature. It is merely apparent, as when the wind of the Bay of Biscay, as Huxley says, "selects the right kind of sand and spreads it in heaps upon the plains." But in thus denying design in nature, these writers array against themselves the intuitive perceptions and irresistible convictions of all mankind, - a barrier which no man has ever been able to surmount. Sir William Thomson, in the address already referred to, says: "I feel profoundly convineed that the argument of design has been greatly too much lost sight of in recent zoölogical speculations. Reaction against the frivolities of teleology, 
such as are to be found, not rarely, in the notes of the learned commentators on 'Paley's Natural Theology,' has, I believe, had a temporary effect of turning attention from the solid irrefragable argument so well put forward in that excellent old book. But overpowering proof of intelligence and benevolent design lie all around us, and if ever perplexities, whether metaphysical or scientific, turn us away from them for a time, they come back upon us with irresistible force, showing to us through nature the influence of a free will, and teaching us that all living beings depend upon one everacting Creator and Ruler."

It is impossible for even Mr. Darwin, inconsistent as it is with his whole theory, to deny all design in the constitution of nature. What is his law of heredity? Why should like beget like? Take two germ cells, one of a plant, another of an animal; no man by microscope or by chemical analysis, or by the magic power of the spectroscope, can detect the slightest difference between them, yet the one infallibly develops into a plant and the other into an animal. Take the germ of a fish and of a bird, and they are equally indistinguishable; yet the one always under all conditions develops 
into a fish and the other into a bird. Why is this? There is no physical force, whether light, heat, electricity, or anything else, which makes the slightest approximation to accounting for that fact. To say, as Stuart Mill would say, that it is an ultimate fact, and needs no explanation, is to say that there may be an effect without an adequate cause. The venerable $R$. E. Von Baer, the first naturalist in Russia, of whom $\Lambda$ gassiz speaks in terms of such affectionate veneration in the "Atlantic Monthly" for January, 1874, has written a volume dated Dorpat, 1873, and entitled "Zum Streit iiber den Darwinismus." In that volume, as we learn from a German periodical, the author says: "The Darwinians lay great stress on heredity; but what is the law of heredity but a determination of something future? Is it not in its nature in the highest degree teleological ? Indeed, is not the whole faculty of reproduction intended to introduce a new lifeprocess? When a man looks at a dissecterl insect and examines its strings of eggs, and asks, Whence are they? the naturalist of our day has no answer to give, but that they were of necessity gradually produced by the changes in matter. When it is further asked, Why are 
they there? is it wrong to say, It is in order that when the eggs are mature and fertilized, new individuals of the same form should be produced."

It is further to be considered that there are innumerable cases of contrivance, or evidence of design in nature, to which the principle of natural selection, or the purposeless changes effected by unconscious force, cannot apply; as for example, the distinction of sex, with all that is therein involved. But passing by such cases, it may be asked, what would it avail to get rid of design in the vegetable and animal kingdom, while the whole universe is full of it? That this ordered Cosmos is not from necessity or chance, is almost a self-evident fact. Not one man in a million of those who ever heard of God, either does doubt or can doubt it. Besides how are the cosmical relations of light, heat, electricity, to the constituent parts of the universe, and especially, so far as this earth is concerned, to vegetable and animal. life, to be accounted for? Is this all chance work? Is it by chance that light and heat cause plants to carry on their wonderful operations, transmuting the inorganic into the organic, dead matter into living and life sustain- 
ing matter? Is it without a purpose that water instead of contracting, expands at the freezing point? - a fact to which is due that the earth north of the tropic is habitable for man or beast. It is no answer to this question to say that a few other substances have the same peculiarity, when no good end, that we can see, is thereby accomplished. No man is so foolish as to deny that his eye was intended to enable him to see, because he cannot tell what the spleen was made for. It is, however, useless to dwell upon this subject. If a man denies that there is design in nature, he can with quite as good reason deny that there is any design in any or in all the works ever executed by man.

The conclusion of the whole matter is, that the denial of design in nature is virtually the denial of God. Mr. Darwin's theory does deny all design in nature, therefore, his theory is virtually atheistical; his theory, not he himself. He believes in a Creator. But when that Creator, millions on millions of ages ago, did something, - called matter and a living germ into existence, - and then abandoned the universe to itself to be controlled by chance and necessity, without any purpose on his 
part as to the result, or any intervention or guidance, then He is virtually consigned, so far as we are concerned, to non-existence. It has already been said that the most extreme of Mr. Darwin's admirers adopt and laud his theory, for the special reason that it banishes God from the world; that it enables them to account for design without referring it to the purpose or agency of God. This is done expressly by Büchner, Haeckel, Vogt, and Strauss. The opponents of Darwinism direct their objections principally against this element of the doctrine. This, as was stated by Rev. Dr. Peabody, was the main ground of the earnest opposition of Agassiz to the theory. America's great botanist, Dr. Asa Gray, avows himself an evolutionist; but he is not a Darwinian. Of that point we have the clearest possible proof. Mr. Darwin, after explicitly denying that the variations which have resulted in "the formation of the most perfectly adapted animals in the world, man included, were intentionally and specially guided," adds : "However much we may wish it, we can hardly follow Professor Asa Gray in his belief 'that variation has been led along certain beneficial lines' like a stream 'along definite 
and useful lines of irrigation.'" 1 If Mr. Darwin does not agree with Dr. Gray, Dr. Gray does not agree with Mr. Darwin. It is as to the exclusion of design from the operations of nature that our American, differs from the English, naturalist. This is the vital point. The denial of final causes is the formative idea of Darwin's theory, and therefore no teleologist can be a Darwinian.

Dr. Gray quotes from another writer the sentence, "It is a singular fact, that when we can find how anything is done, our first conclusion seems to be that God did not do it;" and then adds, "I agree with the writer that this first conclusion is premature and unworthy; I will add, deplorable. Through what faults of dogmatism on the one hand, and skepticism on the other, it came to be so thought, we need not here consider. Let us hope, and I confidently expect, that it is not to last; that the religious faith which survived without a shock the notion of the fixedness of the earth itself, may equally outlast the notion of the absolute fixedness of the species which inhabit it; that in the future, even more than in the past, faith

1 Variation of Plants and Animals under Domestication. New York, 1868, vol. ii. pp. 515, 516. 
in an order, which is the basis of science, will not - as it cannot reasonably - be dissevered from faith in an Ordainer, which is the basis of religion." I We thank God for that sentence. It is the concluding sentence of Dr. Gray's address as ex-President of "The American Association for the Advancement of Science," delivered August, 1872.

Dr. Gray groes further. He says, "The proposition that the things and events in nature were not designed to be so, if logically carried out, is doubtless tantamount to atheism." Again, "To us, a fortuitous Cosmos is simply inconceivable. The alternative is a designed Commos. . . . If Mr. Darwin believes that the events which he supposes to have occurred and the results we behold around us were undirected and undesigned; or if the physicist believes that the natural forces to which he refers phenomena are uncaused and undirected, no argument is needed to show that such belief is atheistic." 2

We have thus arrived at the answer to our

1 Proceedings of the American Association for the Advancement of Science. Cambridge, 1873, p. 20.

2 The Atlantic M Ionthly for October, 1860. The three articles in the July, August, and October numbers of the Atlantic, on this subject, have been reprinted with the name of Dr. Asa Gray as their author. 
question, What is Darwinism? It is Atheism. This does not mean, as before said, that Mr. Darwin himself and all who adopt his views are atheists; but it means that his theory is atheistic; that the exclusion of design from nature is, as Dr. Gray says, tantamount to atheism.

Among the last words of Strauss were these : "We demand for our universe the same piety which the devout man of old demanded for his God." "In the enormous machine of the universe, amid the incessant whirl and hiss of its jagged iron wheels, amid the deafening crash of its ponderous stamps and hammers, in the midst of this whole terrific commotion, man, a helpless and defenceless creature, finds himself placed, not secure for a moment that on an imprudent motion a wheel may not seize and rend him, or a hammer crush him to a powder. This sense of abandonment is at first something awful." 1

1 Strauss says that as he has arrived at the conclusion that there is no personal God, and no life after death, it would seem to follow that the question, Have we still a religion? "must be answered in the negative." But as he makes the essence of religion to consist in a sense of dependence, and as he felt himself to be helpless in the midst of this whirling universe, he had that much religion left. 
Among the last words of Paul were these: "I know whom I have believed, and am persuaded. that $\mathrm{He}$ is able to keep that which $I$ have committed unto Him against that day. . . . The time of my departure is at hand. I have fought a good fight, I have finished my course, I have kept the faith: henceforth there is laid up for me a crown of righteousness, which the Lord, the righteous judge, shall give me at that day: and not to me only, but unto all them also that love his appearing." 


\section{The Great Theological Work of the Age.}

\section{DR. HODGE'S THEOLOGY.

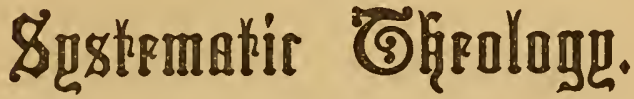

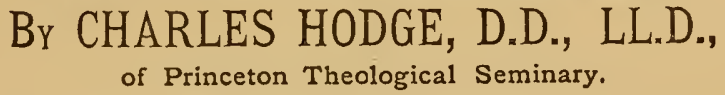

Complete in three volumes 810 , tinted paper. Price, vols. I. and II., \$4.50. Vol. III., \$5.

In these volumes are comprised the results of the life-long labors and investigations of one of the most eminent theologians of the age. The work covers the ground usually or upred by treatises on Systematic Theology, and adopts the commonly received divisions o he subject,-THEOLOGY, Vol. I. ; ANTHROPOLOGY, Vol. II. ; SOTERIOLOG : AND ESCHATOLOGY, Vol. III.

The INTRODUCTION is devoted to the consideration of preliminary matters, such it: Method, or the principles which sho:sld guide the student of Theology, and the differe * theories as to the source and standard of our knowledge of divine things, Rationalist. Mysticism, the Roman Catholic doctrine of the Rule of Faith, and the Protestant doctri, on that subject.

The department of THEOLOGY proper includes the origin of the Idea of God, th. Being of God, the Anti-Theistic systems of Atheism, Polytheism, Materialism, ane Pantheism; the Nature of God, the Divine Attributes, the Doctrines of the Trinity, th. Divinity of Christ, and of the Holy Spirit ; the Decrees of God. Creation, Providence, ar. Misacles.

The lepartment of ANTHROPOLOGY includes the Nature, Origin, and Antiquity r Man, his Primitive State and Probation; the Fall; the Effect of Adam's Sin upon himse. and upon his Posterity; the Nature of $\mathrm{Sin}$; the Different Philosophical and Theologic. Theories on that subject.

SOTERIOLOGY includes the Plan or Purpose of God in reference to the Salvation n Men ; the Person and Work of the Redeemer; his Offices as Prophet, Priest, and King the Work of the Holy Spirit in applying the redemption purchased by Christ; Commo' and Efficacious Grace, Regeneration, Faith, Justification, Sanctification, the Law or Ru: of Life, and the means of Grace.

ESCHATOLOGY includes the State of the Soul after Death : the Second Coming a Clrist ; the Resurrection of the Body ; the General Judgment and End of the World, as. the Doctrine concerning Heaven and Hell.

The plan of the author is to state and vindicate the teachings of the bible on thes various subjects, and to examine the antagonistic doctrines of different classes of Theolv gians. His book, therefore, is intended to be both didactic and elenchtic.

The various topics are discussed with that close and keen analytical and logical powe: combined with that simplicity, lucidity, and strength of style which have already given $1 \%$. HoDGe a world-wide reputation as a controversialis! and writer, and as an investigator the great theological problems of the day.

Sirgle copies sent post-paid on reccipt of the irice.

SCRIBNER, ARMS : HONG \& CO.,

651 Bronduay, New Tork 


\section{THE}

\section{Jistary of Liome,}

FRUM THE EARLIEST TIME TO THE PERIOD OF ITS DECLINE.

\section{By Dr. THEODOR MOMMSEN.}

Iranslated, with the author's sanction and additions, by the Rev. W. P. Dickson, Regitis Professor of Biblical Criticism in the University of Glasgow, late Classical Examiner ir the University of St. Andrews. With an Introduction by Dr. Leonhard Schmitz, ard a copious Index of the who'e four volumes, prepared especially for this edition.

\section{REPRIN'TED FROM THE REVISED LONDON EDITION}

Four Volumes crown 8vo.

Price per volume, \$2.00.

Dr. Mommsen has long been known and appreciated through his 1 ssearches into the languages, laws, and institutions of Ancient Rome and Italy, as the most thoroughly versed scholar now living in these departments of his. torical investigation. To a wonderfully exact and exhaustive knowledge of these subjects, he unites great powers of generalization, a vigorous, spirited, and exceedingly graphic sty!e and keen analytical powers, which give this bistory a degree of interest and a permanent value possessed by no other record of the decline and fall of the Roman Commonwealth. "Dr. Mommsen's work," as Dr. Schmitz remarks in the introduction, "though the production of a man of most profound and extensive learning and knowledge of the world, is not as much designed for the professional scholar as for intelligent readers of all classes who take an interest in the his. tory of by-gone ages, and are inclined there to seek information that may guide them safely through the perplexing mazes of modern history."

\section{CRITICAL NOTICES.}

" A work of the very highest merit : its learning is exact and profound : its narrative full of genins and skill ; its descriptions of men are admirably vivid. We wish to place on record our opinion that Dr. Mommsen's is by far the best history of the Decline and Fall of the Roman Commonwealth." - London Times.

" Since the days of Niebuhr, no work on Roman History has appeared that combines so much to attract, instruct, and charm the reader. Its style-a rare quality in a German au. thor-is vigorous, spirited, and animated. Professor Mommsen's work can stand a com. parison with the noblest productions of modern history." -Dr. Sckmitz.

"This is the best history of the Roman Republic, taking the work on the whole-the author's complete mastery of his subject, the variety of his gifts and acquirements, his graphic power in the delineation of national and individual character, and the vivid interest which he inspires in every portion of his book. He is without an equal in his own sphers."

- Edinburgh Retrieve.

"A houk of deepest interest" - Mear Trench. 


\section{ANOTHER GREAT HISTORICAL WORK.}

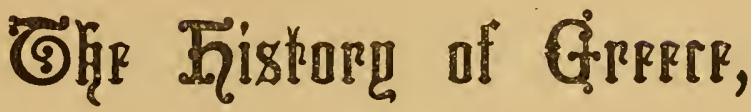 \\ By Prof. Dr. ERISST CURTIUS.}

\section{Translated by ADOLPHUS WILLIAM WARD, M.A., Fellow of St. Peter's College, Cambridge, Prof, of History in Owen's College, Manchester.}

To be completed in four or five vols., crown $\$ v 0$, at $\$ 2.50$ per volume.

Printed upon Tinted Paper, Uniform with Mommsen's History of Rome, and tus Library Edition of Froude's History of England.

VOLS. I., II., III., AND IV., NOW READY.

Curtius' History of Greece is similar in plan and purpose to Mommsen's History of Rome, with which it deserves to rank in every respect as one of the great masterpieces of historical literature. Avoiding the minute details which overburden other similar works, it groups together in a very picturesque manner all the important events in the history of this kingdom, which has exercised such a wonderful influence upon the world's civilization. The narrative of Prof. Curtius' work is flowing and animated, and the generalizatinns, although bold, are philosophical and sound.

\section{CRITICAL NOTICES.}

"Professor Curtius' eminent scholarship is a sufficent guarantee for the trustworthiness of his history, while the skill with which he groups his facts, and his effective mode of narrating them: combine to render it no less readable than sound. Professor Curtius everywhere maintains the true dignity and impartiality of history, and it is evident his sympathies are on the side of justice, humanity, and progress." - Louton Athenceum.

"We can not express our opinion of Dr. Curtius' hook better than by saying that it nay be fitly ranked with Theodor Mommsen's great work." - London . Spectator.

"As an introduction to the study of Grecian history, no previous work is comparable to the present for vivacity and picturesque beauty, while in sound learning and accuracy cf statement it is not inferior to the elaborate productions which enrich the literature of the age." $-N, Y$. Daily T'ribune.

"The History of Greece is treated by Dr. Curtius so broadly and frecly in the spirit of the nineteenth century, that it becomes in his hands one of the worthiest and most instruct.ve branches of study for all who desire something more than a knowledge of isolated far'ts for their education. This translation ouglit to become a regular part of the accepted course of reading for young men at college, and for all who are in training for the free pulitical life of our countr:"."-N. Y. Evening Post.

This bowk seni sost-paid, upon receipt of the price, by the Publishers,

\section{SCRIBNER, ARMSTRONG \& CO.,}

654 BROADWAY, NEW York. 


\section{PROSPECTUS}

OF A

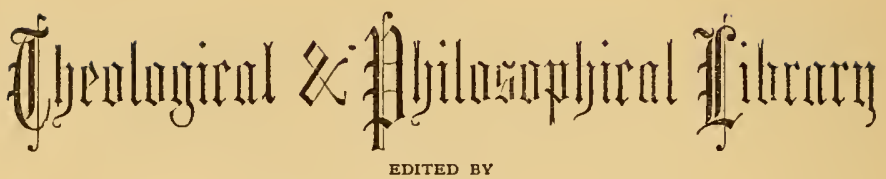

HENRY B. SMITH, D.D., AND PHILIP SCHAFF, D.D.,

Professors in the Union Theological Seminary, Neze York.

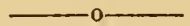

The undersigned propose to pullish a select and compact Library of Text-Books upon all the main departments of Theology and Philosophy, adapted to the wants especially of ministers and students in all denominations.

Some of the works will be translated from the German and other languages ; others wiil be based upon treatises by various authors; some will be written for the Library by English or American scholars. The aim will be to furnish at least one cundensed standard work on each of the scientific divisions of Theulogy and Philosophy, giving the result of the best critical investigations, excluding, however, such histories and comnentaries as extend through many volumes.

This scheme is not presented as final, but as indicating the aim of the editors. If suffcient encouragement be given, no pains will be spared to make the project complete, and thus to meet a great and acknowledged desideratum in the apparatus for study. On all these topics every student needs, at least, one g od work. 'T'o supply this will be the aim of our Library.

The varinus volumes will be published in the best style, on reasonable terms, and as rapidly as the nature of the work and the encouragement of the public will allow.

The editors will be assisted by eminent scholars of various denominations, who will respectively assume the literary responsibility for the volumes prepared by themselves within the general plan and aim of the library.

\section{NOW READY,}

IN

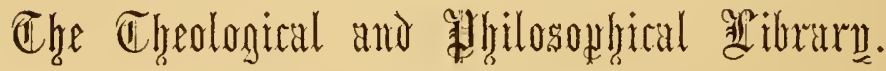

\section{UEBERWEG'S HISTORY OF PHILOSOPHY.}

Vol. I. - History of the Ancient and Mediezal Philosophy. By Dr. Friedrich Ueberweg Translated from the fourth German edition by George S. Morris, A.M., with.addition by Noah Porter, D.D., LL.D., President of Yale College, and a general Introdicticus" by the editor of the Philosophical Library. One vol. 8 vo, cloth, $\$ 3.50$.

VoL. II. - History of Modern Philosophy. With an Essay on English Plilosophy, by Dr. Noah Porter, President of Yale College; and on Italian Plilosopliy, by Pro. fessor V. Botta. One vol. Svo, cl th. \$ \$4.00.

Sent, post-paid, upon receipt of the price by the Publishers,

SCRIBNER, ARMSTRONG \& CO.,

654 BROADWAY, NEW YORK. 


\section{LANGE'S COMIMENTARY.}

\section{NOW READY :

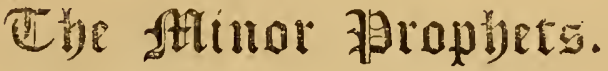

Edited by Rev. DR. PHILIP SCHAFF, and including

HOSEA.-By OtTo SChMoller, Ph. D., Urach, Wurtemberg. Translated, with additions, by JAmes E. MCCURdy.

JOEL.-By OtTo SchMOller, Ph. D. Translated, with additional Notes and a New Version of the Hebrew Text, by JOHN FORSYTH, D.D., LL.D.

AMOS.-By OTto SchMollek, Ph. D. Translated and enlarged by TALBOT $W$. Chambers, D.D.

OBADIAH - By PAUL KLEINERT, of Berlin. Translated, with additions, by GEORGE R. BL1SS, D.D.

JONAH.-By Paul Kleinert. Trans- lated and enlarged by CharLes ElLiotT, D.D.

MICAH.-By PALL Kleinert. Translated, with additions, by GEORGE $R$. BLISS, D.D.

NAHUM, HABAKKUK, AND ZEPHANIAH.-By PAUL. KLEINERT. Translated and enlarged by CHARLES ELLIOTT, D.D.

HAGGAI.-By JAMES F. MCCuRdy, Princeton, N. Y.

ZECHARIAH.-By TALBOT W. ChaMBERS, D.D., New York.

MALACHI.-ByJOSEPII PACKARD, D.D. Alexandria, $\mathrm{Va}$.

One vol. royal $8 \mathrm{vo}$, cloth........................................ $\$ 5$

The Volumes previously Published are:

OLD TESTAMENT. - I. GENESIS. II. JOSHUA, JUDGES, and RUTH. III. FIRST and SECOND KINGS. IV. PSALMS. V. PR()VERES, SONG OF SOLOMON, ECCLESIASTES. VI. JEREMIAH and LAMENTATIONS.

NEW TESTAMENT. - I. MATTHEW. II. MARK and LUKE. III. JOHN. IV. ACTS. V. THE EPISTLE OF PAUL TO THE ROMANS. VI. CORINTHIANS. VII. CiALATIANS, EPHESIANS, PHILIPPIANS, COLOSSIANS. VIII. THESSALONIANS, TIMIOTHY. TITUS, PHILEMON, and HEBREWS. IX. TIE EPISTLES GENERAL OF JAMES, PETER, JOHN, and JUDE.

Each one vol. 8vo. Price per vol., in half calf, \$7.50; in sheep, \$6.50: in cloth, \$5.00.

\section{NAIMES AND DENOMINATIONS OF CONTRIBUTORS.}

W. G. T. SHEDD, D.D., Presbyterian. E. A. WASHBURNE, D.D., Episcopal. A. C. KENDRICK, D.D., Baptist. W. H. GRE.EN, D.D., Presbyterian. J. F. HURST, D.D., Methodist. TAYLER LEIVIS, LI..D., Dutch Reformed. Rev. CH. F. SHAFFER, D.D., Lutheran. R. D. HITCHCOCK, D.D., Presbyterian. E. HARIVOOD, D.D., Episcopal. If. B. HACKETT, D.D., Baptist. Ji) HN LILLIE, D.D., Presbyterian. KEV. W. G. SUMNER, Episcopal. Pror. CHARLES ELLIOTT, Presbyterian. THOS. C. CONANT, D.D., Baptist.
E. D. YEOMANS, D.D., Presbyterian.

REv. C. C. STARBUCK, Congregational. J. ISIDOR MOMBERT, D.D., Episcopal. D. W. POOR, D.D., Presbyterian. C. P. WING, D.D., Presbyterian.

GEORGE E. DAY' D. D., Congregational. REv. P. H. STEENSTRA, Episcopal.

A. GOSMAN, D.D., Presbyterian. Pres. CHAS. A. AIKEN, D.D., Presbyt'n. M. B. RIDDLE, D.D., Dutch Reformed. Prof. WM, WELLS, D.D., Methodist. W. H. HORNBLOWER, D.D., Presbyt'n Prof. GEORGE JLISS, Baptist.

T. W. CHAMBERS, D. D., Reformed.

W Each volume of "LANGE: S COMMENTARY" is complete in itself, and can be purchased separately. Sent, post-paid, to any address upon receipt of the price ( $\$ 5$ pes volume) by the publishers, 


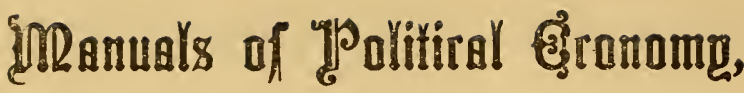

PUBLISHED BY

\section{SCRIBNER, ARMSTRONG \& CO.}

\section{Perry's Elemenis of Political Economy.}

New EdTton, Revised by the Author.

This treatise presents views favorable to the utmost freedom of com. merce, compatible with legitimate revenue from tariff taxes. It is a standard text-book in all our colleges throughout the country. By Arthur Latham Perry, Professor of Political Economy and History in Williams College. 487 pages, price $\$ 2.50$.

"Your book interests students more than any other I have ever instructed from." Pres. T. D. Woolsey, Yale Collegi.

"As a manual for general reading and popular instruction, Prof. Perry's book is far superior to any work on the subject before issued in the United States." $-N$. Y. Times.

"We cordially recommend this book to all, of whatever school of political economy, who enjoy candid statement and full and logical discussion." $-N$. Y. Nation.

"There is more common sense in this book than in any of the more elaborate works on the same subject that have preceded it." $-N$. $Y$. Indeperdent.

"In all the portions of the book which we have read, the author shows himself to be a clear, strong, bold, and generally sound thinker."-Neze Englander.

\section{Bowen's American Political Economy.}

This treatise presents views compatible with the idea that " every country has a political economy of its own, suitable to its own physical circum. stances of position on the globe, and to the character, habits, and institutions of the people." By Francis Bowen, Professor of Political Economy and Civil Polity in Harvard College. 495 pages, price \$2.50

"If our members of Congress would vote themselves a copy of this book, and read it, fewer wild scuemes would be concocted by them, and a great saving of time and the people's inoney would be secured."-The Philadelpliza Ag'e.

"His arguments are worth considering, and his whole book is of high value to any American to study economical questions." - Springfield Republican.

"A solid and well-reasoned treatise. . . . Mr. Bowen's views are clearly stated and thoroughly reasoned." - Boston Congregationalist.

- . "There are hundreds going wrong to-day whom a careful perusal of this volume would set right." $-N$. Y. Daily Tribune.

Sent, post-paid, on receipt of price by the publishers. 
[PUI'ULARLY KNOWN IN ENGLAND AS "THE SPEAKER'S COMMELT.ARY".
A Plain Explanatory Exposition of the Holy Scriptures for every Bible Reader.

To be publlshed at regular intervals, in royal octavo volumes, at the uniform prac: of $\$ 5.00$ per volume.

with OCCASIONAL ILLUSTRATIONS.

The great object of the BIBLE COMMENTARY is to put every general retder and atu dent in full possession of whatever information may be necessary to enable him to unaerstand the Holy Scriptures; to give him, as far as possible, the same advantages as the Scholır, and to sumply him with satisfactory answers to objections resting upon misrepresentations or misinterpretations of the text. To secure this end most effeetually, the Comment is chiefly explanatory, presenting in a eoneise and readable form the results of learned investigations carried on during the last half century. When fuller discussions of diffieult passages or im portant subjects are necessary, they are placed at the end of the ehapter or volume.

The text is reprinted without alteration, from the Authorized Version of 1611, with marginan references and renderings; but the notes forming this Commentary will embody amended translations of passages proved to be ineorrect in that version.

The work will be divided into EIGHT SEC'TIUNS, which it is expected will be comprised in as many volumes, and eneli volume will be a royal octavo Typographically, special pains Las been taken to adapt the work to the nse of older readers and students.

N.B. - The Amcrican edition of the Bilsle Commentary is printed from stereotype platus, duplicated from those upon which the English edition is printed, and it is fully ecpunl to that in every respect.

\section{NOW READY.-FOUR VOLUMES.}

Section I.-The Pentateuch. GENESIS.-By Rt. Rev. E. HAROLD BROWNE, D.D.

EXODUS, Chap. I.-XIX.-By THE ED. ITOR.

EXODUS, Chap. XX to the end.-By Rev. Samuel Clark, M.A.

LEVITICUS.-By Rev. Samuel Clark, M.A.

NUMBERS AND DEUTERONOMY. -By Rev. T. E. Espin, B.D.

\section{Section II.-The Historical Books.} PART I.

JOSHUA.-By Rev. T. E. Esprn, P.D. JUDGES, RUTH, SAMUEL - By Rt. Rev. Lord Arthur Hervey, M.A.

FIRST KINGS.-By Rev. GEORGE RAwLiNSON, M.A.

PART 11.

SECOND KINGS, CHRONICLES, EZ. RA, NEHEMIAH, ESTHER.-By Rev. George. Rawlinson.

\section{Section III.-The Poetical Books.}

JOB............... THE EDITOR.

PSALMIS ............. $\left\{\begin{array}{l}\text { Very Rev. G. H. S. Johnson, M.A., author of Sermons } \\ \text { Preached in Wells Cathedral. } \\ \text { The EDitor. } \\ \text { Rev. C. I. ELLiotT, M. A. }\end{array}\right.$ PROVERBS ........... $\left\{\begin{array}{c}\text { Rev. I. II. PLUmp'TRE, M.A., author of Christ and Chris- } \\ \text { temd.m (Boyle Lectures), Sermons on Theology and Life, }\end{array}\right.$ JCCLESIASTES........ R R R. W. Pullock, M.A., Secretary to the S. P. G. SONG OF SOLOMÖ... - Rev. T'. Kingsburv, M.A., 'T'rinity College, Cambridge.

Each volume of the Speaker's Commentary is complete in itself, and is sold separately Cloth, $\$ 5.00$; sheep, $\$ 6.50$; half calf, $\$ 7.50$.

SCRIBNER, 19RSTRCNA, \& CO., 654 Broadway, N. Y. 


\section{THE NOVEL OF THE YEAR.}

\section{ARTHUR BONNICASTLE,}

By Dr. J. G. HOLLAND,

Author of "Bitter-Sweet," "Fathrina," "Titcomb's Letters," dec.

\section{WITH TWELVE FULL-PAGE ILLUSTRATIONS BY MARY A. HALLOCK.}

\section{One Vol. $12 \mathrm{mo}, \$ 1.75$}

ARTIUR BonNiCASTLE is the most mature and finished prose work of its popular author. Autobiographic in form, it is partly so in material likewise; and while of thrilling interest as a story, it presents the ripe results of a life of earnest action and thought. The great lesson of the book is self-respect and self-reliance-the evil influence of dependence being exemplified in different characters and circumstances, by the youth of Arthur and the life of Peter Mullens. For character-drawing, purpose, pathos, style and savor of the soil, ARTHUR BONNICASTIE is remarkable among the norels of the time.

\section{DR. HOLLAND'S WORKS.}

Each in One Volume $12 \mathrm{mo.}$

\footnotetext{
- bitter-swelt; a Poem . . \$150 MISS GILBERT'S CAREER . . \$200

* kathrina; a Poem . . . 150

* Letters to yodNG PeOPLE, 150 BAY PATH . . . . . 2 ก GOLD-FOIL, hammered from Popular Proverbs . . . . 175 * LeSSONS IN LIFE . . . 175

* PLAIN TALKS on Familiar Subjects . . . . . 175 LETTARS TO THE JONESES • 1 T5

THE MIARLE PROPHECY, and cther Poems. . . . 130

GARNERED SHEAVES, Complete Poetical Works, "Bitter-Sweet," " Kathrina," "Marble Phrophecy," red line edition, beautifully illustrated. . . . . 400

* These six volumes are issued in Cabinet sizo (16mo), "Brightwood Edition," at the Eame prices as ahove.
} 


\section{Prices and Styles of tine Different Editions \\ or}

\section{FROUIF'S HISTORY OF ENGLANI).}

\section{Che Cbelsea goition.}

Ia hall roan, gilt top, per set of twelve vols. $r 2 \mathrm{mo} \ldots \ldots \ldots \ldots \ldots \ldots \ldots \ldots$. $\$$.

Elegance and cheapness are combined in a remarkable degree in this edition. It takes ke name from the place of Mr. Froude's residence in London, also famous as the hom: of Thornas Carlyle.

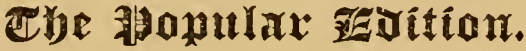

In cloth, at the rate of $\$ 1.25$ per volume. The set ( 12 vo!s.), in a neat box. $\$ 15.00$ The Same, in half calf extra....................................... $3^{6 . \infty}$

This edition is printed from the same plates as the other editions, and on firm, white paper. It is, without exception, the cheapest set of books of its class ever issued in this country.

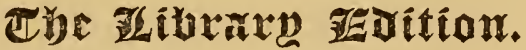

In twelve vols. crown $8 \mathrm{vo}$, cloth............................\$30..

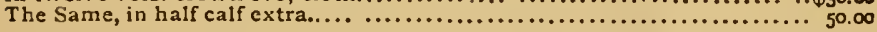

The Edition is printed on laid and tinted paper, at the Riverside Press, and is in every respect worthy a place in the most carefully selected library.

\section{SHORT STUDIES ON GREAT SUBJECTS.}

\section{By James An'rhony Froude, M. A., "History of Englind," "The English in Ireland during the Eighteenth Century," etc.}

POPULAR EDITION. Two vols. 12mo, cloth, $\$ 1.50$ per vol. The Set....\$3.0 CHELSEA EDITION. Two vols. I $2 \mathrm{mo}$, half roan, gilt top, $\$ 2.00$ per vol-

ume. Per Set............................................... 4.00

\section{The Complete Works of James Anthony Froude, M.A.}

HISTORY OF ENGLAND AND SHORT STUDIES.

Fourteen vols., in a neat Box,

POPULAR EDITION........................................ \$1 ¿IIELSEA EDITION...................................... 25

The above works sent, post-paid, by the publishers, on receipt of the orice

SCRIBNER, ARMSTRONG \& CO., 


\title{
Popular and Strandarm Works
}

pronsistron nx

\section{SCRIBNER, ARMSTRONG \& CO.,}

\author{
654 Broaduay, New York,
}

\section{IN 1873.}

1. BAGEHOT'S (W.) LOMBARD STREE'T, 12mo................... 1 \%

2. BIBLE COMMENTARY. Vol. II. Svo...................... 500

3. " " Vol. III. Sro.....................

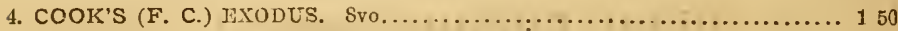

5. DIEULAFAIT'S (L.) DIAMONDS AND PRECIOUS STONES. Inustrated.

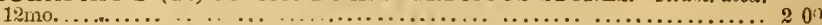

6. DODGE'S (MRS. MARY MAPES) HANS BRINKER. Illustrated. 12mo. 150

7. FIELD'S (T. W.) INDIAN BIBLIOGRAPHY. 8vo.............. 5 (0)

8. FISHER'S (DR. G. P.) HISTORY OF THE REFORMATION. 8vo ...... 3 CO

9. GUYOT'S (PROF. A.) PHYSICAL GEOGRAPHY. Large 4to.......... 225

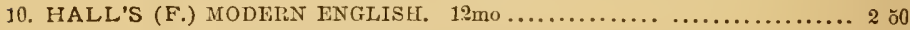

11. " " FALSE PHILOLOGY. $12 \mathrm{mo}$, boards................. 125

12. HOLLAND'S (DR. J. G.) ARTHUR BONNICASTLE. Mlustrated, 12mo.. 175

13. HOPKINS' (DR. M.) OUTLINE STUDX OF MAN. $12 \mathrm{~m} \cap \ldots \ldots \ldots \ldots \ldots \ldots$....... 1 i5 THE ILLUSTRATED LIBRARY OF TRAVEL AND ADVENTURE.

Each 1 vol. 12 mo cloth......................................... 150 14. Central Africa.

15. Siam as It $\mathrm{W}$ as and Is.

THE LIBRARY OF CHOICE FICTION:

16. The Burgomaster's Family. Svo. Cloth, $\$ 1.50 ;$ paper........... 100

17. Wandering Willie. Svo. Paper ......................... 50

18. Galama. svo. Cloth, $\$ 1.25$; paper........................

19. May. By Mrs. Oziphant. 8vo. Cloth, $\$ 1.50 ;$ paner............ 100

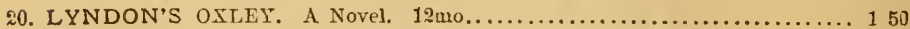

21. MEDHURST'S (W. H.) THE FOREIGNER IN FAR CATHAY. 12 mo... 150

22. PERR'Y'S (PROF. A. L.) POLITICAL ECONOMIY. 11th edition revised.

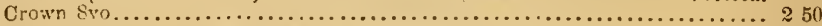

23. SAXE HOLM'S STORIES. 12mo, extra gilt, $\$ 1.75$; plain............. 150

24. STANLEY'S (H. M.) MY KALULU. Illustrater. 12mo..............201)

¿5. UEBERWEG'S (PROF. F.) HISTORY OF PHILOSOPHY. Vol. II. Svo.. 400 26. VERNE'S (JULES) FROMI THE EARTH TO THE MOON. Ilustrated.

Crown svo........................................... 300

27. VERNE'S (JULES) JOURNEY TO THE CENTRE OF THE EARTH.

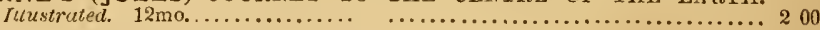

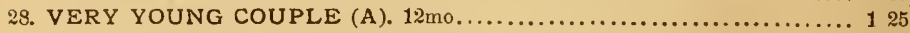

*** 1ny of tho above bools sent postpald to any address upon receipt of the price by the jublishers. 





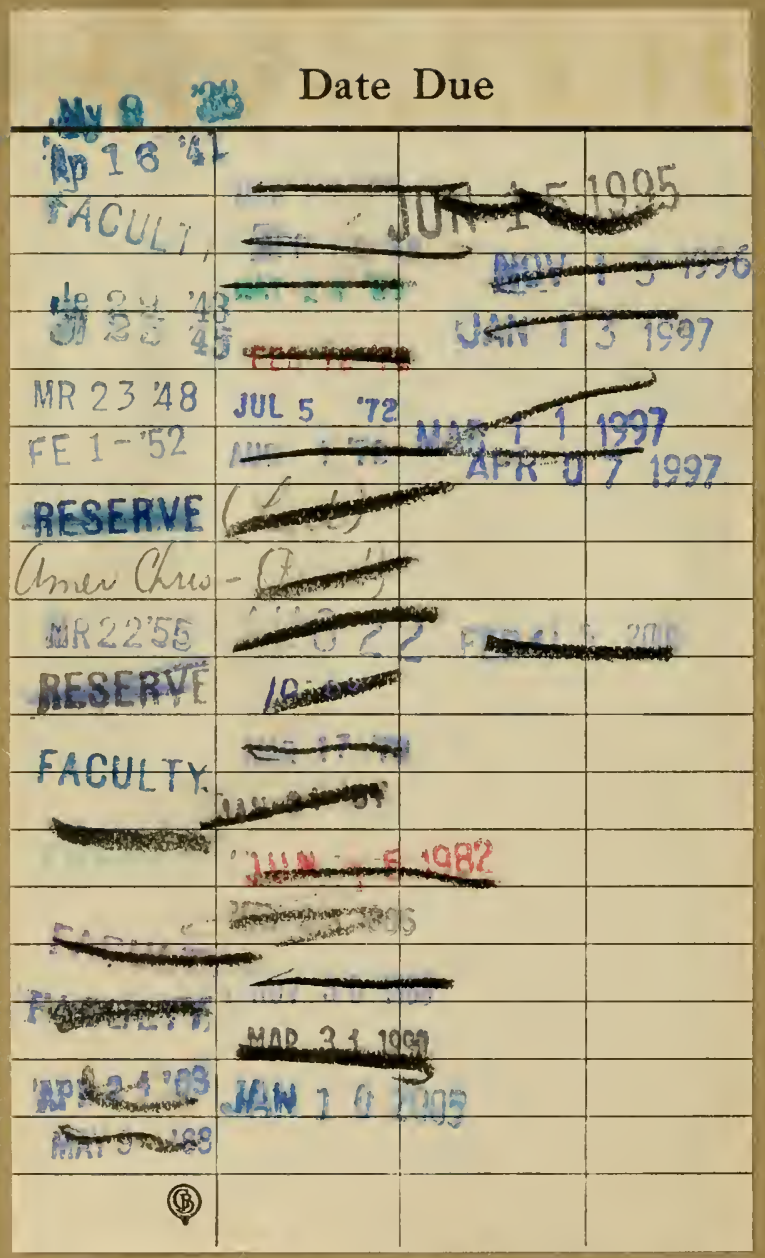




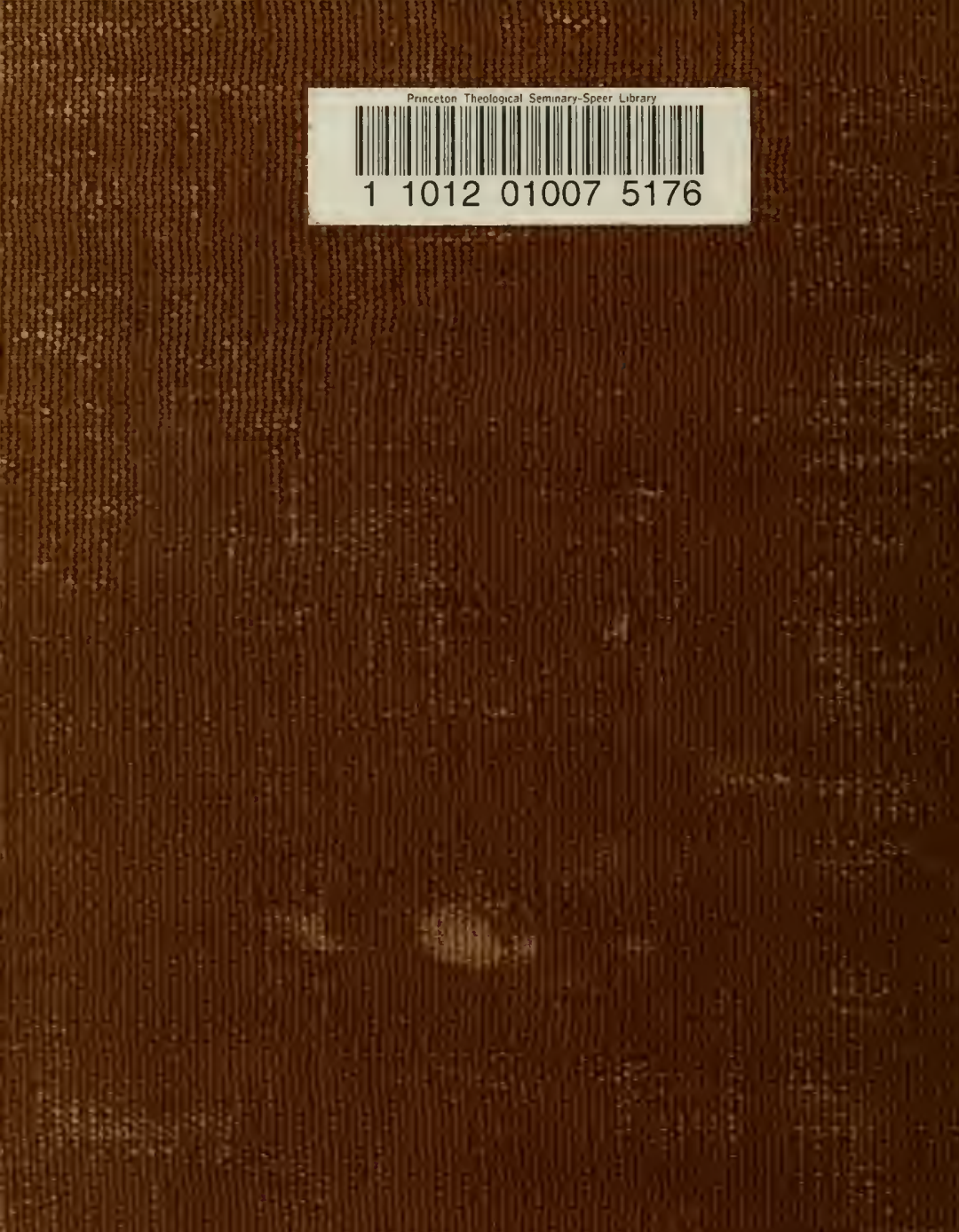